Fabyane de Oliveira Teixeira Garcia

\title{
Identificação de microRNAs na saliva associados ao benefício a longo prazo da quimiorradioterapia em pacientes com carcinoma epidermoide de cavidade oral e orofaringe.
}

Dissertação apresentada à Faculdade de Medicina da Universidade de São Paulo para obtenção do título de Mestre em Ciências.

Programa de Oncologia

Orientadora: Dra. Fátima Solange Pasini

(Versão corrigida. Resolução CoPGr 6018/11, de 1 de novembro de 2011. A versão original está disponível na Biblioteca da FMUSP) 
Fabyane de Oliveira Teixeira Garcia

\section{Identificação de microRNAs na saliva associados ao benefício a longo prazo da quimiorradioterapia em pacientes com carcinoma epidermoide de cavidade oral e orofaringe.}

Dissertação apresentada à Faculdade de Medicina da Universidade de São Paulo para obtenção do título de Mestre em Ciências.

Programa de Oncologia

Orientadora: Dra. Fátima Solange Pasini

(Versão corrigida. Resolução CoPGr 6018/11, de 1 de novembro de 2011. A versão original está disponível na Biblioteca da FMUSP)

São Paulo, 2017 
Dados Internacionais de Catalogação na Publicação (CIP)

Preparada pela Biblioteca da

Faculdade de Medicina da Universidade de São Paulo

Creprodução autorizada pelo autor

Garcia, Fabyane de Oliveira Teixeira

Identificação de microRNAs na saliva associados ao benefício a longo prazo de quimiorradioterapia em pacientes com carcinoma epidermoide de cavidade oral e orofaringe / Fabyane de Oliveira Teixeira Garcia. -- São Paulo, 2016.

Dissertação(mestrado)--Faculdade de Medicina da Universidade de São Paulo. Programa de Oncologia.

Orientadora: Fátima Solange Pasini.

Descritores: 1.Neoplasias de cabeça e pescoço 2.Carcinoma de células escamosas 3.Quimiorradioterapia 4.MicroRNAs 5.Saliva 6.Exossomos

USP/FM/DBD-326/16 
"Por vezes sentimos que aquilo que fazemos não é senão uma gota de água no mar. Mas o mar sería menor se the faltasse uma gota."

Madre Tereza de Calcutá. 
Dedico esse trabalho as pessoas mais importantes da minha vida:

Ao meu amado esposo Diego Garcia, pelo carinho e apoio incondicional.

Ao meu filho Lorenzo, que chegou para transformar minha vida e me fazer uma pessoa melhor.

Aos meus pais Alaíde e Fábio e meus irmãos Tatyane e Higor pelo que eu sou. 


\section{AGRADECIMENTOS}

Primeiramente a Deus, por ter me sustentado e capacitado para vencer mais essa etapa. Pelo dom da vida e pela família que me foi concedida.

A toda minha família, em especial meus pais por toda dedicação que tiveram a mim e por terem sempre incentivado meus estudos. Agradeço também a família do meu esposo, que há tempos também é minha.

Ao meu esposo, Diego, por ter sido minha fortaleza durante esses anos. Por todo carinho, compreensão e incentivo.

Agradecimento especial à minha orientadora, Dra. Fátima Solange Pasini, pela oportunidade de desenvolver esse projeto, pela paciência, por ter sido tão presente e por todo o conhecimento compartilhado. Agradeço em especial pela amizade que construímos ao longo desse processo, pelo apoio e compreensão nos momento de dificuldades e por ser responsável pela realização de um sonho!

Ao prof. Dr. Roger Chammas pela oportunidade em realizar esse projeto.

Ao Dr. Gilberto de Castro Júnior pelo auxílio na parte clínica desse projeto e por toda disponibilidade e atenção desprendidas.

Aos médicos assistentes do grupo de Oncologia Torácica e Tumores de Cabeça e Pescoço do ICESP, pela ajuda e atenção na inclusão dos pacientes, em especial a Dra Milena Perez Mak pela ajuda não só na inclusão de pacientes como também na discussão de prontuários.

Às pesquisadoras e amigas Tatyane Furuya, Maria Lucia Hirata Katayama, Rosimeire Roella e Simone Maistro por contribuírem com minha formação e aprendizado e pela amizade que vivenciamos durante esses anos.

A todos os amigos de laboratório pelos momentos de convívio, discussões científicas e partilhas pessoais, em especial agradeço às amigas Giselly Zanetti, Simone Vieira, Tárcia Carvalho, Karina Alves e Vivian Marinelli.

A todos os docentes e discentes do programa de pós-graduação em Oncologia pelo convívio e ensinamentos.

A todos os funcionários do Lim 24 e do CTO (Centro Translacional de Pesquisa em Oncologia) por toda ajuda ao longo desses anos.

Ao Dr Marcelo Alves Ferreira do Laboratório de Biologia Celular (LIM-59) pelo auxílio na realização dos experimentos de microscopia eletrônica.

À Gabriela Oliveira, pós-doutoranda do Centro Internacional de Pesquisa do A.C. Camargo Câncer Center, pelo auxílio na realização dos experimentos no Nanosight. 
A minha banca de qualificação: Profa. Dra. Edna Teruko Kimura, Dra Raquel Adjub Moyses e Dra. Luciana Nogueira de Souza Andrade pelas sugestões e críticas que engrandeceram esse projeto.

Agradeço em especial a todos os pacientes, que mesmo em meio a todo sofrimento doaram um pouco de si e de seu tempo para contribuírem com a ciência. A vocês toda minha gratidão!

À FAPESP pelo auxilio financeiro a esse projeto, sob o número 2013/25397-0 e à CAPES pela bolsa de mestrado. 


\section{Sumário}

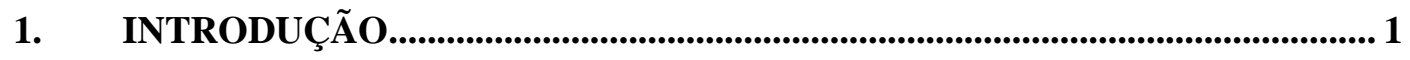

1.1. Epidemiologia........................................................................................................................ 1

1.2. Câncer de Cabeça e Pescoço ............................................................................ 2

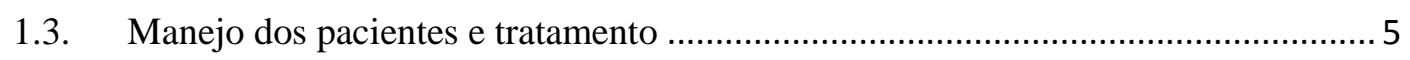

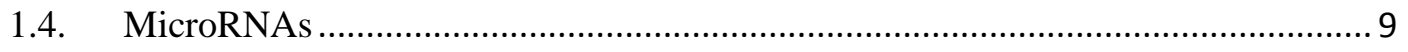

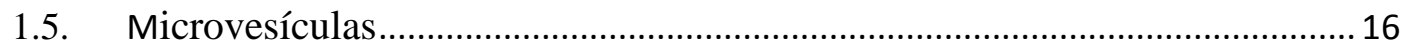

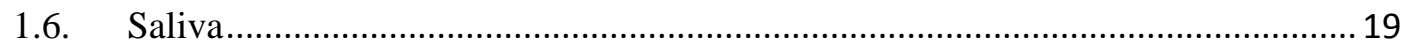

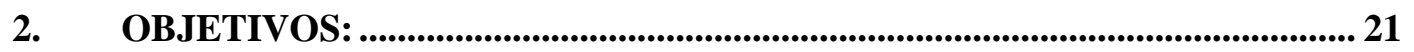

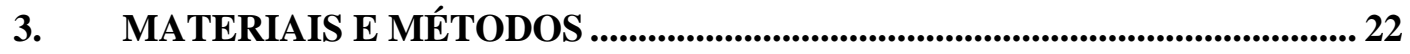

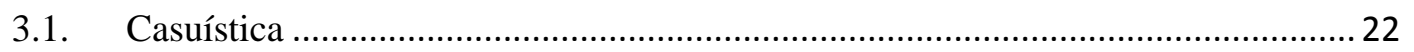

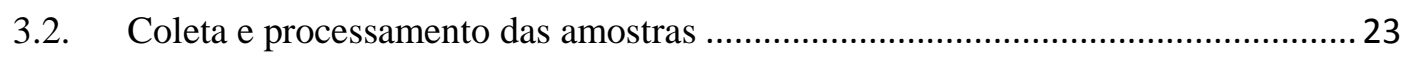

3.3. Separação de microvesículas .................................................................................... 24

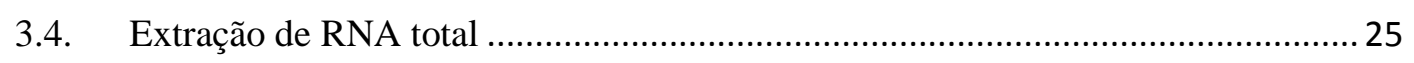

3.5. Revisão da literatura e escolha dos microRNAs de interesse................................. 27

3.6. RT-qPCR (Transcrição Reversa-Reação em Cadeia da Polimerase quantitativa) 28

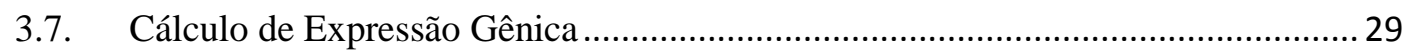

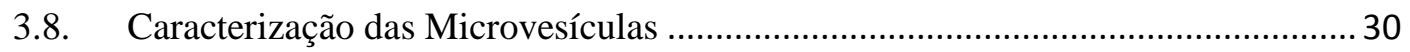

3.9. Análises dos resultados e considerações estatísticas ................................................ 34

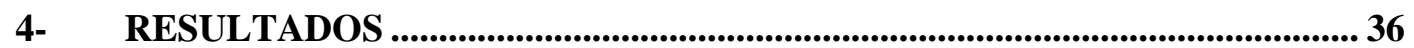

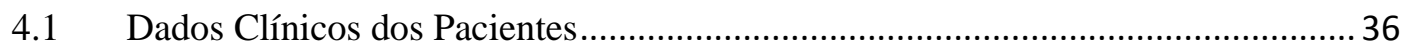

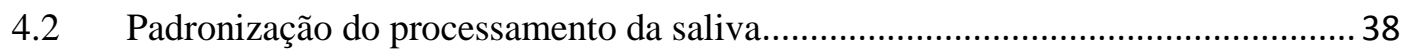

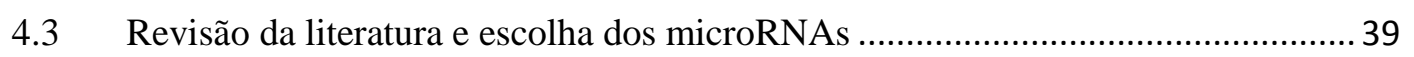

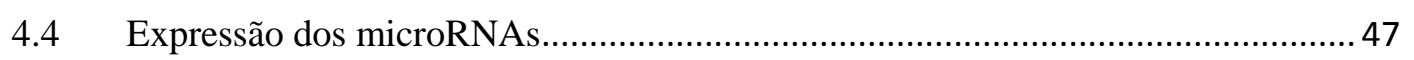

4.5 Visualização e quantificação de microvesículas ...................................................57

4.6 Expressão de microRNAs contidos nas microvesículas...........................................61

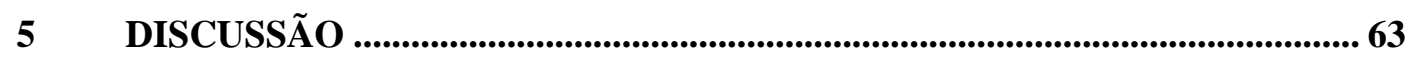

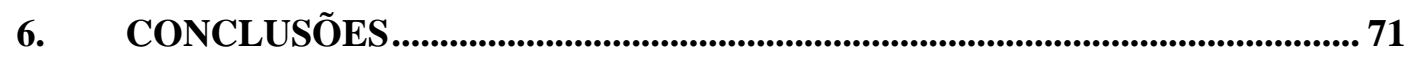

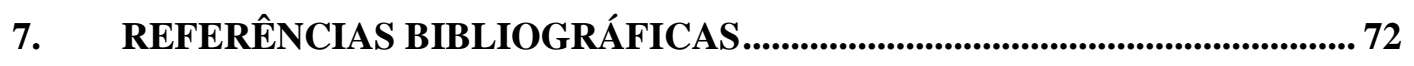

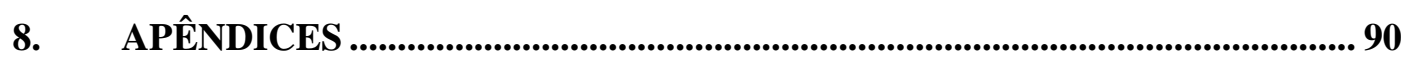




\section{LISTA DE FIGURAS}

Figura 1 - Distribuição proporcional dos dez tipos de câncer mais incidentes estimados para 2016 por sexo, exceto pele não melanoma (INCA; 2016) ................................................. 2

Figura 2- Principais adutos formados através da interação da cisplatina com DNA. ............. 6

Figura 3 - Biogênese dos microRNAs (via canônica) (Barca-Mayo et al.,2012)................... 11

Figura 4 - Esquema da interação entre miR e o mRNA-alvo.............................................. 13

Figura 5 - Biogênese dos exossomos e Microvesículas ...................................................... 17

Figura 6 - Fluxograma com a descrição do processamento da saliva. ................................... 23

Figura 7 - Desenho esquemático do sistema miRCURY LNA............................................ 28

Figura 8 - Sistema Nanosight (Nanosight Range)......................................................... 32

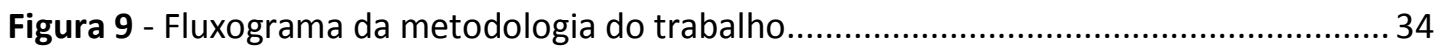

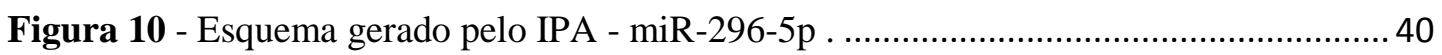

Figura 11 - Esquema gerado pelo software IPA - miR-200b ........................................ 43

Figura 12 - Esquema gerado pelo software IPA, miR-21 e miR23a .................................. 44

Figura 13 - Adaptação do esquema gerado pelo software IPA- miR-125b.......................... 45

Figura 14 - Esquema adaptado do IPA - miR-142-3p regula GFI1 …................................. 46

Figura 15 - Esquema adaptado do IPA - miR-503-5p .................................................. 47

Figura 16 - Representação da expressão do miR-15a-5p (A), miR-21-5p (B), miR-23a-3p

(C) e miR-125b-5p (D) em cada um dos grupos estudados.............................................. 50

Figura 17 - Representação da expressão do miR-142-3p (E) e miR-200b-3p (F) em cada um

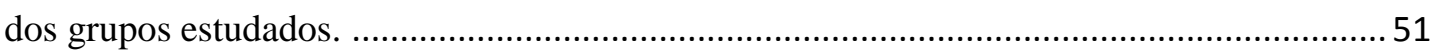

Figura 18 - Representação da expressão do miR-21-5p em relação ao tabagismo (A) e etilismo (B) e do miR-200b-3p em relação ao etilismo (C) . ............................................... 53

Figura 19 - Curvas de Kaplan-Meier para a sobrevida livre de progressão dos pacientes do

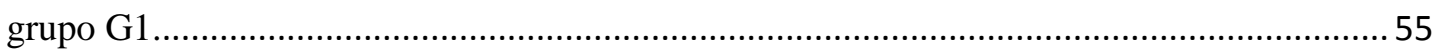

Figura 20 - Curvas de Kaplan-Meier para sobrevida global dos pacientes do grupo G1 ...... 56

Figura 21 - Identificação de microvesículas por Microscopia Eletrônica de Transmissão .. 58

Figura 22 - Comparação entre os grupos, contagem total de partículas $(0-805 \mathrm{~nm})$ e

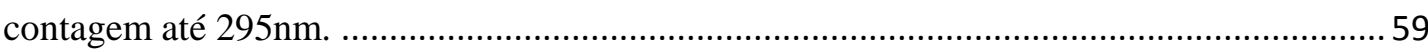

Figura 23 - Histograma com a distribuição do número de partículas por tamanho. .............. 60

Figura 24 - Quantificação da proteína CD63 por ELISA................................................... 61

Figura 25 - Comparação dos valores de Ciclo Treshould (Ct) do miR-21-5p entre saliva total, Microvesículas e sobrenadante livre de Mvs separadas por exoquick..........................62

Figura 26 - Comparação dos valores de Ciclo Treshould (Ct) do miR-21-5p entre saliva total e Mvs separadas por ultracentrifugação. 


\section{LISTA DE TABELAS}

Tabela 1 - Dados clínicos dos pacientes separados por grupo. 37

Tabela 2 - Dados demográficos do grupo controle e voluntários sadios. 38

Tabela 3- Alguns artigos incluídos que relacionam a expressão dos microRNAs, miR-200, miR-21 e miR-15 a quimio ou radiorresistência.

Tabela 4 - Análise descritiva da expressão dos microRNAs analisados nas amostras de saliva de pacientes com OSCC inoperáveis e de volunatários sádios.

Tabela 5 - Comparação da expressão relativa dos microRNAs nos diferentes grupos de amostras

Tabela 6 - Associação da expressão dos microRNAs com avaliação de resposta ao tratamento nos pacientes do grupo 1 ........................................................ 54

Tabela 7 - Análise de sobrevida para os pacientes do grupo G1. 56

Tabela 8- Análise descritiva da quantificação de partículas em cada um dos grupos estudados.

\section{LISTA DE SIGLAS}

CCP - Câncer de Cabeça e Pescoço

CEC - Carcinoma Epidermoide

CECP - Carcinoma Epidermoide de Cabeça e Pescoço

Cts - Ciclo threshould

DNA- Ácido Desoxirribonucléico/ cDNA- Ácido Desoxirribonucléico complementar

IPA - Ingenuity Pathway Analysis

ME - Microscopia Eletrônica

MVs - Microvesículas

PBS - Tampão Fosfato Salino (do inglês Phosphate buffered saline)

QRT - Quimiorradioterapia

qRT-PCR - Transcrição Reversa - Reação da Polimerase em cadeia quantitativa

RNA - Ácido Ribonucléico

SLC - Saliva Livre de Células

SLMvs - Sobrenadante Livre de microvesículas 


\section{GLOSSÁRIO}

AKT1 - AKT Serine / Threonine Kinase 1

BCL2 - Apoptosis Regulator

BMI1 - BMII Proto-Oncogene, Polycomb Ring Finger

CCND1 - cyclin D1

COL1A1 - Collagen Type I Alpha 1 Chain

ICAM2 - Intercellular Adhesion Molecule 2

MMR - Mismatch Repair

NER - Nucleotide Excision Repair

PCNA - Proliferating Cell Nuclear Antigen

PTEN - Phosphatase And Tensin Homolog

TP53 - Tumor Protein P53

TWIST1 - Twist Family Bhlh Transcription Factor

XIAP - X-Linked Inhibitor Of Apoptosis

ZEB1/ZEB2 - Zinc Finger E-Box Binding Homeobox $1 / 2$ 


\section{Resumo}

Fabyane de Oliveira Teixeira Garcia. Identificação de microRNAs na saliva associados ao benefício a longo prazo da quimiorradioterapia em pacientes com carcinoma epidermoide de cavidade oral e orofaringe [Dissertação]. São Paulo: Faculdade de Medicina, Universidade de São Paulo, 2016.

INTRODUÇÃO: A maioria dos pacientes com CECP é diagnosticada em estágios avançados da doença, apresentando taxas de sobrevida insatisfatórias. Em carcinomas localmente avançados e irressecáveis, o tratamento padrão na rotina do ICESP é a QRT a base de cisplatina. Entretanto, cerca de dois terços desses pacientes apresentam recidiva local, à distância ou óbito em cinco anos. Entender os mecanismos de resistência a QRT e descobrir marcadores que possam indicar resposta ao tratamento continuam sendo um desafio. Os microRNAs possuem papel chave nos mecanismos de resistência a QRT, sendo possível quantificá-los em saliva. Neste estudo avaliamos a expressão de microRNAs na saliva de pacientes com CEC de cavidade oral e orofaringe e se esses microRNAs estão contidos dentro de microvesículas. MÉTODOS: Por meio de revisão da literatura e análises in sílico, selecionamos 8 microRNAs para serem avaliados: miR-15a-5p, 21-5p, 23a-3p, 125b5p, 142-3p, 200b-3p, 296-5p e 503-5p. A expressão dos microRNAs foi determinada por PCR quantitativo na saliva livre de células de 70 pacientes portadores de CEC de cavidade oral e orofaringe localmente avançado e irressecável, em diferentes estágios da progressão da doença: antes de iniciar tratamento (G1), com falha do tratamento (G2) e livre da doença há 2 anos (G3) e em 28 voluntários sadios (G0). Microvesículas foram isolados por ultracentrifugação ou exoQuick, analisados por Microscopia Eletrônica de Transmissão (MET), Nanosight e para determinação da expressão do miR-21-5p. RESULTADOS: Os miRs-296-5p e 503-5p foram indetectáveis na maioria das amostras testadas. Quando comparamos os grupos em diferentes situações clínicas, encontramos diferença significativa na expressão do $\operatorname{miR}-21-5 \mathrm{p}(\mathrm{p}=0.005), \operatorname{miR}-23 \mathrm{a}-3 \mathrm{p}(\mathrm{p}=0,026), \operatorname{miR}-125-5 \mathrm{p}(\mathrm{p}=0,013), \operatorname{miR}-142-3 \mathrm{p}$ $(\mathrm{p}=0,033)$ e miR-200b-3p ( $\mathrm{p}=0,031)$. Observou-se aumento na expressão dos miRs $21-5 \mathrm{p}(\mathrm{p}=0,001), 23 \mathrm{a}-3 \mathrm{p}(\mathrm{p}=0,004), 125 \mathrm{~b}-5 \mathrm{p}(\mathrm{p}=0,026)$ e $142-3 \mathrm{p}(\mathrm{p}=0,005)$ na saliva dos pacientes em G1 em relação ao voluntários sadios $(\mathrm{G} 0)$. O grupo G3 também apresentou maior expressão do mir-21-5p $(\mathrm{p}=0,018), 125 \mathrm{~b}-5 \mathrm{p}(\mathrm{p}=0,002)$ e $200 \mathrm{~b}-3 \mathrm{p}$ ( $\mathrm{p}=0,014)$ comparado ao $\mathrm{G} 0$, assim como o grupo $\mathrm{G} 2$ teve maior expressão do mir$15 \mathrm{a}-5 \mathrm{p}(\mathrm{p}=0,023)$ e 23a-3p (p=0,017) comparado ao grupo G0. O grupo G2 apresentou menor expressão do miR-200b-3p (p=0,019) e maior expressão do miR$15 a-5 p(p=0,057)$ em relação ao grupo G3. Além disso, os pacientes tabagistas e/ou etilistas apresentaram maior expressão relativa do miR-21-5p $(p=0,001$ e $p=0,046$, respectivamente) e os etilistas também tiveram maior expressão do miR-200b-3p $(\mathrm{p}=0,013)$. Com relação à resposta inicial do paciente ao tratamento avaliada pelo médico bem como, com a resposta a longo prazo (recidiva, status global e prognóstico), a expressão dos miR-15a-5p, miR-125b-5p, miR-23a-3p e miR-142-3p apresentaram associação com sobrevida livre de progressão e sobrevida global, porém não atingiram significância estatística. Microvesículas foram detectadas na saliva tanto na MET como na contagem no nanosight. A expressão do miR-21-5p foi predominantemente detectada dentro de microveículas em relação ao sobrenadante livre de vesículas. CONCLUSÕES: Alguns dos microRNAs analisados foram diferencialmente expressos entre os diferentes grupos estudados, a expressão do miR-21 foi associada ao tabagismo e etilismo e a do miR-200b com etilismo e a 
expressão de alguns microRNAs podem estar associadas à resposta ao tratamento e ao prognóstico dos pacientes.

Descritores: Neoplasias de cabeça e pescoço, Carcinoma de células escamosas, Quimiorradioterapia, MicroRNAs, Saliva, Exossomo. 


\begin{abstract}
Fabyane de Oliveira Teixeira Garcia. Identification of microRNAs in saliva associated with long-term benefit of chemoradiotherapy in patients with squamous cell carcinoma of the oral cavity and oropharynx [Dissertation]. São Paulo: Faculdade de Medicina, Universidade de São Paulo, 2016.
\end{abstract}

BACKGROUND: Most patients with HNSCC are diagnosed in advanced stages of the disease, with unsatisfactory survival rates. In locally advanced and unresectable carcinoma, the standard treatment in ICESP is cisplatin based QRT. However, about two-thirds of these patients have local recurrence, distance or death within five years. Understanding the QRT resistance mechanisms and discovery of markers that may indicate benefit of treatment is a great challenge. MicroRNAs have key role in the mechanisms of QRT resistance and are detectable in saliva. In the present study we analyzed the expression of microRNAs in the saliva from oral cavity/oropharynx squamous cell carcinoma (OSCC) patients and whether these microRNAs are contained within exosomes. METHODS: Through a review of studies in the literature and by in silico analysis, we choose 8 microRNAs to be evaluated: miR15a-5p, 21-5p, 23a-3p, 125b-5p, 142-3p, 200b-3p, 296-5p and 503-5p. The expression of microRNAs was determined by quantitative PCR in the cell-free saliva from 70 locally advanced and unresectable OSCC patients at different stages of disease progression: treatment naive (G1), after treatment failure $(\mathrm{G} 2)$ and disease free for at least 2 years (G3) and 28 healthy volunteers (G0). Exosomes were isolated by ultracentrifugation or exoQuick, analyzed by transmission electron microscopy (MET), Nanosight quantification and by determination of the miR-21-5p expression. RESULTS: The miRs-296-5p and 503-5p were undetectable in almost all saliva samples. Significant differences was observed in the expression of miR-21-5p $(\mathrm{p}=0.005), \operatorname{miR}-23 \mathrm{a}-3 \mathrm{p}(\mathrm{p}=0.026), \operatorname{miR}-125-5 \mathrm{p}(\mathrm{p}=0.013) \operatorname{miR}-142-3 \mathrm{p}(\mathrm{p}=0.033)$ and miR-200b-3p ( $\mathrm{p}=0.031)$ among the groups analyzed. The expression of miRs $21-5 \mathrm{p}$ $(p=0.001), 23 a-3 p(p=0.004), 125 b-5 p(p=0.026)$ and 142-3p $(p=0.005)$ were high in saliva of G1 patients as compared to heath volunteers (G0). The G3 group also showed higher expression of mir-21-5p $(p=0.018), 125 b-5 p(p=0.002)$ and 200b-3p $(\mathrm{p}=0.014)$ and $\mathrm{G} 2$ presented higher expression of miR-15a-5p $(\mathrm{p}=0.023)$ and $23 \mathrm{a}-3 \mathrm{p}$ $(\mathrm{p}=0.017)$ as both compared to the G0. The group G2 presented lower expression of the miR-200b-3p ( $p=0.019)$ and higher expression of the miR-15a-5p ( $\mathrm{p}=0.057)$ as compared to the G3 group. In addition, saliva from the smokers and/or drinkers patients showed high relative expression of the miR-21-5p ( $\mathrm{p}=0.001 \mathrm{e} p=0.046$; respectively) compared to former drinker/smokers and drinkers also showed high expression of the miR-200b-3p $(\mathrm{p}=0.013)$. In relation to the initial response to treatment assessed by the physician, as well the long-term response (relapse, global status and prognosis), the expression of the miR-15a-5p, miR-125b-5p, miR-23a-3p e miR-142-3p showed association with progression-free survival and overall survival, however did not reach statistical significance. Microvesicles were detected in saliva by both MET as the count in nanosight. The expression of the miR-21-5p was predominantly detected in microvesicles in relation to the supernatant. CONCLUSIONS: Some of the microRNAs analyzed were differentially expressed between the different groups, the expression of the miR-21 was associated with smoking and drinking habits and of the miR-200b with drinking habits and the expression of some microRNAs may be associated with the treatment response and prognosis of the patients. 
Descriptors: Head and Neck neoplasms, Squamous cell carcinoma, Chemoradiotherapy, MicroRNAs, saliva, Exosomes. 


\section{Introdução}

\section{1. - Epidemiologia}

O câncer de cabeça e pescoço (CCP) é um termo amplo que abrange tumores epiteliais que surgem nos seios paranasais, cavidade nasal, cavidade oral, faringe e laringe. O carcinoma epidermoide é o tipo de neoplasia mais frequente acometendo cerca de $90 \%$ desses tumores, enquanto os tipos basocelulares, adenocarcinomas, e de pequenas células são menos comuns (WHO, 2010).

Mundialmente, o carcinoma epidermoide de cabeça e pescoço (CECP) é o sexto tipo de câncer mais comum acometendo cerca de 686.000 novos casos por ano, destes 300.000 casos correspondem a tumores de lábios e cavidade oral, sendo esperado 145.000 casos de mortes (Ferlay et al, 2015). Existe grande variação na incidência geográfica desses tumores, sendo o sudeste da Ásia, regiões do pacífico, parte da América Latina e partes da Europa central e Oriental as regiões com as maiores taxas de incidência; na Índia é o tipo de câncer mais comum, compreendendo cerca de $40 \%$ de todas as neoplasias (Warnakulasuriya et al., 2009).

Segundo estimativas do Instituto Nacional do Câncer, para o biênio 2016-2017 o Brasil terá cerca de 420.000 mil casos novos de câncer por ano, excetuando-se os casos de câncer de pele não melanoma (cerca de 180 mil casos novos). Sendo 51\% (214.350) incidente no sexo masculino e 48\% (205.960) no sexo feminino. Os tipos mais frequentes em homens serão próstata, pulmão, intestino, estômago e cavidade oral; enquanto nas mulheres será mama, intestino, colo do útero, pulmão e estômago (Figura $1)$.

Para o biênio 2016-2017 estima-se 11.140 casos novos de tumores de cavidade e oral e orofaringe em homens e 4.350 em mulheres. A incidência do câncer da cavidade oral varia entre as regiões brasileiras, para os homens figura entre a quarta (Sudeste 14,58/100 mil) e a sétima posição (Norte - 3,46/100 mil) e para as mulheres entre a nona (Nordeste $-4,11 / 100$ mil) e $15^{\circ}$ posição (Sul - 3,32/100 mil), sem considerar os tumores de pele não melanomas (INCA; 2016). 
Distribuição proporcional dos dez tipos de câncer mais incidentes estimados para 2016 por sexo, exceto pele não melanoma*

\begin{tabular}{|c|c|c|c|c|c|c|c|}
\hline Localização Primária & Casos & $\%$ & & & Localização Primária & Casos & $\%$ \\
\hline Próstata & 61.200 & $28,6 \%$ & Homens & Mulheres & Mama feminina & 57.960 & $28,1 \%$ \\
\hline Traqueia, Brônquio e Pulmão & 17.330 & $8,1 \%$ & & & Cólon e Reto & 17.620 & $8,6 \%$ \\
\hline Cólon e Reto & 16.660 & $7,8 \%$ & & & Colo do útero & 16.340 & $7,9 \%$ \\
\hline Estômago & 12.920 & $6,0 \%$ & & & Traqueia, Brônquio e Pulmão & 10.890 & $5,3 \%$ \\
\hline Cavidade Oral & 11.140 & $5,2 \%$ & & & Estômago & 7.600 & $3,7 \%$ \\
\hline Esôfago & 7.950 & $3,7 \%$ & & & Corpo do útero & 6.950 & $3,4 \%$ \\
\hline Bexiga & 7.200 & $3,4 \%$ & & & Ovário & 6.150 & $3,0 \%$ \\
\hline Laringe & 6.360 & $3,0 \%$ & & & Glândula Tireoide & 5.870 & $2,9 \%$ \\
\hline Leucemias & 5.540 & $2,6 \%$ & & & Linfoma não Hodgkin & 5.030 & $2,4 \%$ \\
\hline Sistema Nervoso Central & 5.440 & $2,5 \%$ & & & Sistema Nervoso Central & 4.830 & $2,3 \%$ \\
\hline
\end{tabular}

${ }^{\star}$ Números arredondados para múltiplos de 10.

Figura 1 - Distribuição proporcional dos dez tipos de câncer mais incidentes estimados para 2016 por sexo, exceto pele não melanoma (INCA; 2016).

\subsection{Câncer de Cabeça e Pescoço}

CCP é altamente associado com estilo de vida e fatores ambientais, dentre os fatores de risco para o desenvolvimento desta neoplasia destacam-se o tabagismo e o álcool, sendo o tabagismo considerado o principal fator de risco isoladamente, tanto para homens quanto para mulheres, com forte efeito dose-resposta. Quanto maior a quantidade de cigarros e principalmente o tempo de exposição a esse hábito, maior é o risco de desenvolvimento de CECP. Fumo e álcool possuem efeito sinérgico (Lambert et al., 2011, Znaor et al., 2003, Lubin et al., 2009).

A infecção viral é um fator etiológico conhecido para dois sítios específicos em tumores de CCP, HPV (Papiloma Vírus Humano) está associado ao câncer de orofaringe e EBV (Vírus Epstein-Barr) ao carcinoma de nasofaringe (Principe et al., 2013). A relação entre infecção por HPV e câncer de orofaringe foi proposta pela primeira vez por Syrjänen et al. em 1983 e foi posteriormente reforçada por diversos autores (D'Souza et al., 2007; Badulescu et al., 2010; Hocking et al., 2011), sendo o subtipo 16 o mais prevalente (Alibek et al., 2013). A infecção por HPV pode explicar o aumento na incidência de casos de tumores de orofaringe em pacientes jovens e/ou que não tem como hábito o uso de tabaco e álcool (Heck et al., 2010). Os tumores HPV positivos têm sido associados com prognóstico mais favorável. Embora frequentemente eles tenham histologia pouco diferenciada eles são caracterizados por menor taxa de progressão maligna e melhor resposta a quimio e radioterapia quando comparados com 
tumores com mesmo grau e estadiamento, negativo para infecção por HPV (Zhao et al., 2009; Shi et al., 2009; Lambert et al., 2011; Argiris et al., 2008).

Do ponto de vista molecular, tumores HPV positivos são caracterizados por alta instabilidade genômica, devido à desregulação no controle do ciclo celular pelas oncoproteínas E6 e E7 (Wiest et al., 2002). Enquanto os tumores HPV negativos surgem através da cancerização de campo e progressão clonal devido à exposição repetitiva ao carcinógeno, os tumores HPV positivos abrigam menores taxas de mutação e frequentemente menos alterações no número de cópias, a carcinogênese ocorre pelas oncoproteinas E6 e E7 (Bonilla-Velez, 2013; Stransky et al., 2011; Cancer Genome Atlas Network , 2015). Os mecanismos biológicos que explicam a diferença de sobrevida em tumores HPV positivos são multifatoriais. A ausência da cancerização de campo certamente reduz a incidência de recorrência locorregional e segundos primários, a persistência de p53 funcional também pode contribuir para a melhor resposta a quimio e radioterapia (Licitra et al., 2006; Butz et al., 1996).

Cerca de dois terços dos pacientes com CECP são diagnosticados em estágios avançados da doença, III e IV, comumente envolvendo comprometimento de linfonodos regionais, a doença é frequentemente assintomática. Alguns pacientes não procuram assistência médica até que dor, sangramento inexplicado, ulceração da lesão crescimento de massa no pescoço ou na cavidade oral ocorram, mas frequentemente a doença já se encontra em estagio avançado (Nagadia et al., 2013; McCullough, et al., 2012; Argiris et al., 2008). A sobrevida a longo prazo desses pacientes é em torno de $30 \%$ sendo a mortalidade relacionada principalmente a complicações oriundas da recidiva locorregional da doença, de metástases à distância ou do aparecimento de segundos tumores primários (Castro, 2010). Slaughter observa que 11,2\% dos CCPs apresentam um segundo tumor primário (Slaughter et al., 1953).

\subsubsection{Aspectos moleculares de CCP}

Os tumores HPV negativos se originam pelos fatores de risco convencionais, onde a carcinogenese é dependente da aquisição de múltiplas alterações genéticas e epigenéticas levando a alterações prémalignas que podem evoluir para neoplasia maligna invasiva. $\mathrm{O}$ conceito conhecido como cancerização de campo postula que a exposição da mucosa aerodigestiva ao tabaco e álcool desenvolve campos 
geneticamente distintos em que mutações adicionais podem causar a transformação celular. CCP é caracterizado por ser um tumor muito heterogêneo, inclusive a nível molecular. Estudos recentes caracterizaram essa heterogeneidade usando marcadores de microssatélites e hibridização in situ em áreas distintas do tumor e evidenciaram que os tumores primários são mais heterogêneos que as metástases (El-Naggar et al., 1997; Götte et al., 2004).

Mutações em oncogenes não são comuns em CECP. Embora estudos in vitro evidenciem o papel da sinalização de EGFR (Receptor de Fator de crescimento Epidermal - receptor transmenbrana tirosina kinase que ativa a sinalização de Ras e PI3K) em CECP, apenas $15 \%$ dos pacientes apresentam mutação ou amplificação desse gene (Cancer Genome Atlas Network, 2015; Kalyankrishna e Grandis, 2006).

P53 é um supressor de tumor que está alterado em inúmeros canceres humanos, mais de dois terços de CECP apresentam mutações nos exons 5-8 do P53 (Gasco e Crook, 2003; Somers et al., 1992) com predomínio de mutações com perda de função. Mutações em P53 desregulam o ciclo celular, interrompem a apoptose e o monitoramento da integridade genômica, levando a proliferação descontrolada e defeito no reparo do DNA. Alterações na função do P53 normalmente estão associadas à resistência a radiação e quimioterapia a base de cisplatina (Ohnishi et al., 2001; Stransky et al., 2011). Análises realizadas pelo consórcio The Câncer Genome Atlas (TCGA) identificaram que 84\% dos CECP HPV negativos têm mutações em P53 contra $3 \%$ de mutações em CECP HPV positivos. Outra mutação frequente em CECP HPV negativos é no regulador de ciclo celular CDKN2A (58\%) (Cancer Genome Atlas Network, 2015).

O acompanhamento dos pacientes com CECP é difícil devido o tamanho limitado do tumor recorrente, o crescimento e a progressão da doença muitas vezes é oculto e a localização em vários subsítios anatômicos enfatiza a necessidade de biomarcadores confiáveis para melhor manejo do paciente. Isso é especialmente crítico considerando a importância da detecção do tumor antes do desenvolvimento de metástases locorregionais e à distância (Puram e Rocco; 2015). Embora algumas publicações recentes sugiram o uso de DNA circulante hypermetilado como biomarcador diagnostico (Mydlarz et al., 2016) assim como status de HPV e combinação da quantificação de P53, p16, Bcl-2 e EGFR como biomarcadores de prognóstico, não há na prática clínica um biomarcador em fluidos ou tecido que possa 
ser usado no diagnóstico de CECP (Kumar et al., 2008; Nichols et al., 2010; Puram e Rocco; 2015).

\section{3. - Manejo dos pacientes e tratamento}

O desenvolvimento do CECP, bem como seu tratamento, causa impacto significativo na qualidade de vida dos pacientes tanto em termos estéticos quanto funcionais, como dor, desfiguramento e alterações na fala e na deglutição (Coatesworth et al., 2002). Por esta razão, estratégias terapêuticas são adotadas com objetivo de preservar a anatomia e a função do órgão acometido (Sanabria et al., 2010). O manejo eficaz da doença, especialmente em sua fase inicial, pode otimizar a probabilidade de sobrevivência e prevenir e/ou retardar complicações (Streckfus et al., 2007).

Os pacientes com carcinoma localmente avançado são tratados por cirurgia, quando factível, seguida de radioterapia e/ou quimiorradioterapia. Os procedimentos não cirúrgicos são geralmente administrados quando o tumor é considerado irressecável ou com objetivo de preservar o órgão e/ou função. Nestes casos o tratamento padrão é a quimiorradioterapia (QRT) concomitante a base de cisplatina com intuito curativo, alcançando ganho absoluto de $8 \%$ na sobrevida global em cinco anos quando comparado à radioterapia isolada. Todavia, mesmo em pacientes submetidos a tal terapêutica, observa-se que cerca de dois terços dos pacientes apresentam recidiva local, à distância ou óbito em cinco anos (Pignon et al., 2009; Forastiere et al., 1999).

Outra estratégia terapêutica é o uso de quimioterapia de indução (neoadjuvante). Essa estratégia de tratamento diminui o risco de desenvolvimento de metástases e auxilia no controle locorregional da doença (Lorch et al., 2011; Posner et al., 2008; Domenge et al., 2000). Além disso, a quimioterapia também pode ser utilizada na rotina como tratamento padrão em pacientes portadores de doença metastática ou com recidiva locorregional, sem indicação de cirurgia ou reirradiação. Nestes casos a quimioterapia tem um papel paliativo e a sobrevida mediana é limitada, menor que um ano (Fury et al., 2011).

Apesar dos consideráveis avanços nas ferramentas diagnósticas e tratamento nas últimas três décadas, a mortalidade dos pacientes com CECP continua sendo alta, e as modalidades de tratamento são associadas a muitos efeitos adversos e redução de qualidade de vida (Corry et al., 2010). 
O principal objetivo da quimioterapia concomitante é aumentar a atividade citotóxica da radioterapia (Brizel et al., 2006). Tanto a radioterapia quanto a quimioterapia podem ocasionar danos ao DNA, sendo possível que haja um sinergismo entre eles. A radiação ionizante induz danos na base do DNA, sítios alcalinos sensíveis e quebra de uma ou das duas fitas de DNA. Esses danos são passíveis de reparo, mas caso o reparo não ocorra eles são considerados letais para as células (Bennett et al., 1993; Ward, 1998).

A cisplatina é comumente utilizada na QRT concomitante. Ela se liga ao DNA formando adutos, com a formação de ligações inter e intracadeias que induzem alterações estruturais no DNA. As bases purinas (G ou A) do sulco maior do DNA são os sítios preferenciais de ligação das platinas, por serem mais acessíveis e nucleofílicos (Jung et al., 2007; Fuertes et al., 2003). O principal aduto cisplatina-DNA resulta da ligação a duas bases intrafita. Há ainda adutos menos comuns onde a platina se liga a duas bases interfitas ou da ligação a uma fita de DNA e uma proteína, Figura 2 (Jung et al., 2007; Fuertes et al., 2003; Cepeda et al., 2007; Gonzalez et al., 2001; revisado por Neves et al., 2011).

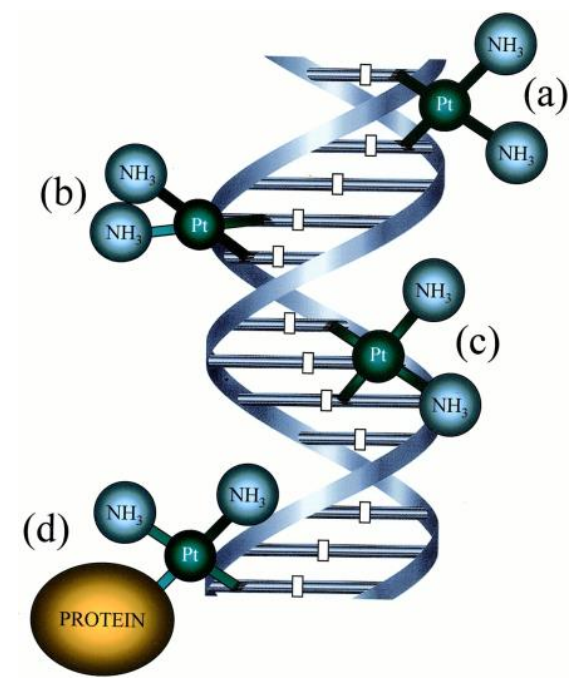

Figura 2- Principais adutos formados através da interação da cisplatina com DNA: (a) ligação interfitas, (b) ligação 1-2 intrafita; (c) ligação cruzada 1-3 intrafita; (d) interação com DNA e proteína (Gonzalez et al., 2001).

A formação dos adutos com a cisplatina provoca distorções significativas na dupla hélice do DNA, causando desenovelamento e torção da sua estrutura (Coste et al., 
1999), que por sua vez são responsáveis pela inibição da transcrição e replicação, com indução de apoptose e necrose (Jung et al., 2007; Fuertes et al., 2003; Jamieson, et al.,1999; Köberle et al., 2010). Uma vez formados, os adutos cisplatina-DNA podem ser reparados, principalmente através do mecanismo de excisão de nucleotídeos. A cisplatina pode dificultar ou inibir o reparo ao dano ocasionado pela radiação ionizante, aumentando a incidência de parada do ciclo celular e morte por apoptose (Begg, 1990; Yang et al., 1995; Wilson et al., 2006; Moreland et al., 1999).

Apesar da alta eficácia da cisplatina, efeitos colaterais, como nefrotoxicidade e neurotoxicidade, além da resistência adquirida à droga após determinado tempo de administração, representam uma limitação a sua utilização. A resposta primária a esse agente normalmente é alta, mas muitos pacientes recidivam com doença resistente a platina. Os mecanismos de resistência à cisplatina propostos incluem: diminuição do acúmulo de droga na célula e aumento do efluxo, desativação do fármaco por proteínas e peptídeos, aumento da biotransformação e detoxificação no fígado, aumento no reparo do DNA e mecanismos antiapoptóticos (Gottesman et al., 2002). Para superar esses mecanismos de resistência, a cisplatina é comumente usada em combinação com outras drogas como o paclitaxel, por exemplo, um agente antimitótico que se liga preferencialmente aos microtubulos inibindo a reorganização da rede de microtubulos (Parness et al., 1981; Jung et al., 2007; Fuertes et al., 2003; Kelland et al., 2007; Wang et al., 2007).

Um dos grandes desafios da pesquisa é buscar entender melhor os mecanismos de resistência a QRT, tendo em vista a perspectiva de desenvolvimento de agentes terapêuticos dirigidos a alvos moleculares. Neste cenário, também é interessante a descoberta de marcadores moleculares associados à recidiva subclínica após quimiorradiação, o que permitiria otimizar as opções de tratamento. Acredita-se que os tumores desenvolvam resistência às quimioterapias através de múltiplas vias de resposta celular que alteram a expressão gênica e proteica. Nos últimos anos, estudos têm evidenciado marcadores associados à resistência a agentes quimioterápicos. Alguns estudos evidenciam a importância de alterações nas vias de reparo do DNA, NER (Nucleotide excision repair) e MMR (mismatch repair) no mecanismo de resistência aos agentes de platina (Aebi et al., 1996, Brown et al., 1997; Fink et al., 1998; revisado por Galluzzi et al., 2012). Tanto a expressão do mRNA (RNA mensageiro) quanto da proteína de ERCC1 têm sido negativamente correlacionadas com a sobrevida e/ou 
resposta a quimioterapia baseada em platina em diversos carcinomas como gástrico (Metzger et al., 1998), cabeça e pescoço (Handra-Luca et al., 2007), esôfago (Kim et al., 2008), colorretal (Shirota et al., 2001) e pulmão (Olaussen et al., 2006); entretanto a relação entre a expressão de ERCC1 com a resistência tumoral ao tratamento não é absoluta, evidenciando que há outros mecanismos moleculares envolvidos nesse processo (Handra-Luca et al., 2007; De Castro et al., 2011).

Embora os papéis das cascatas de sinalização gênicas e das proteínas como fatores regulatórios na quimiorresistência estão se tornando bem estabelecidos, é evidente que há contribuição dos microRNAs neste processo. Além disso, os perfis de expressão de microRNAs, tecido- e doença-específica, são frequentemente mais informativos e discriminatórios do que perfis de mRNA (Calin et al., 2002) e são capazes de discriminar mais precisamente a origem de tumores pouco diferenciados ou cujo primário é desconhecido (Lu et al., 2005; revisto por Reid et al., 2011), o que o torna uma ferramenta para diagnostico inicial de CECP (Kozaki et al.,2008; Wong et al., 2008).

Alguns estudos têm demonstrado que os microRNAs tem um papel chave na resistência a tratamentos quimioterápicos e radioterápicos. Por exemplo, o microRNA221/222 confere resistência ao tamoxifeno em linhagens celulares de câncer de mama (Miller et al., 2008); os mesmos microRNAs (221/222) regulam a radiossensibilidade e crescimento celular em linhagem celular de carcinoma gástrico, possivelmente através da modulação da expressão do PTEN (Chun-Zhi et al., 2010); o microRNA-34a modula a quimiossensibilidade a doxorrubicina e vincristina em células de Sarcoma de Ewing (Nakatani et al., 2012) e a resistência a docetaxel em células de câncer de mama (Kastl et al., 2012), o miR-200 modula a resistência à cisplatina através da regulação do MBI1 em carcinoma de língua (Sun et al., 2012) e ao paclitaxel em carcinoma de ovário através da regulação da $\beta$-tubulina III (Leskelä et al., 2010); os microRNAs-30/130/335 modulam a resistência à cisplatina e ao paclitaxel em carcinoma de ovário (Zou et AL, 2012; Sorrentino et al.,2008); o miR-9 e let-7g aumentam a sensibilidade a radiação ionizante em linhagens de células de câncer de pulmão H1299, por meio da regulação da expressão do NFкB1 (Arora et al., 2011), entre outros. Contudo, o papel desempenhado pelos microRNAs na quimiorresistência em CECP ainda permanece pouco elucidado (Yu ZW et al, 2010; Puram e Rocco; 2015). 


\section{4. - MicroRNAs}

Os microRNAs foram descritos pela primeira vez em 1993 através de dois artigos publicados na mesma edição da revista Cell por dois grupos de pesquisadores liderados por Lee e Wightman (Lee et al., 1993, Wightman et al.,1993). Eles demonstraram pela primeira vez um processo de regulação pós-transcricional mediado por um pequeno RNA antissenso através da hibridização com a região 3' UTR do genealvo. Eles descobriram em Caernorhabditis elegans um pequeno RNA de aproximadamente 22 nucleotídeos não codificante de proteína, mas que reprimia a tradução do lin-14 regulando a transformação do primeiro para o segundo estágio larval no desenvolvimento de nematódeos.

Em 2000, outro pequeno RNA de aproximadamente 22 nucleotideos, let-7, foi descoberto por também regular o desenvolvimento de nematodeos (Reinhart et al., 2000) semelhante ao lin-14. Esse fenômeno chamou a atenção e em outubro de 2001, Lagos-Quintana e colaboradores isolaram e identificaram microRNAs em $D$. melanogaster e células humanas HeLa. Nessa mesma edição da revista Science, Rosalind Lee e Victor Ambros (2001) descreveram novos microRNAs em C. elegans, alguns deles com homólogos no camundongo, drosófila e no homem. A partir dessas publicações ficava claro que os microRNAs eram evolutivamente conservados, presente em várias espécies e potencialmente capazes de regular diversos processos biológicos. Esses pequenos RNAs foram coletivamente denominados microRNAs e suas informações foram incluídas no miRBase (http://microRNA.sanger.ac.uk/).

Os microRNAs são moléculas de RNA simples fita de 19 a 25 nucleotídeos, não codificadores de proteínas, que atuam como potentes reguladores pós-transcricionais, embora exista relatos atípicos de que os miRs podem ter ação pré-transcricional, agindo como fatores de transcrição nuclear (Bartel et al. 2009).

\subsection{1 - Biogênese e Classificação}

O processo de biogênese do microRNA inicia-se no núcleo, passa por modificações pós-transcricionais e termina no citoplasma (Figura 3). A via de maturação canônica tem inicio com a transcrição do gene pela RNA polimerase II ou III em um pri-miRNA, um longo transcrito primário com estrutura em forma de grampo contendo cauda poliadeniladas e cap 5' (Lee et al., 2004). Este ainda no núcleo é 
processado pelo complexo enzimático Drosha (RNA polimerase III e seu co-fator DGCR8) que reconhecem e clivam o pri-miRNA em pré-miRNA, com cerca de 60-100 nucleotídeos também em forma de grampo (Han et al., 2004). O pré-miRNA é exportado do núcleo para o citoplasma pelo complexo exportina-5/Ran-GTP (Kim et al.,2004), onde é clivado pela DICER (RNase III) gerando um transcrito de fita dupla de aproximadamente 22 nucleotídeos, denominado duplex de microRNA (Hutvágner et al., 2001, Ketting et al., 2001). Este duplex se associa ao complexo RISC (RNA-induced silence complex) cuja principal proteína é a argonauta (Khvorova et al., 2003). Uma fita do duplex permanece no complexo RISC como miRNA maduro (fita guia) e completa a biogênese enquanto a outra fita é degradada (fita passageira). O complexo de RISC direciona o microRNA maduro ao mRNA alvo, determinando o silenciamento do mRNA pela inibição da sua tradução quando a complementariedade de bases é incompleta, ou pela degradação do mRNA, quando a complementariedade de bases é total (Bartel, 2009; revisado por Di Leva et al., 2014). 


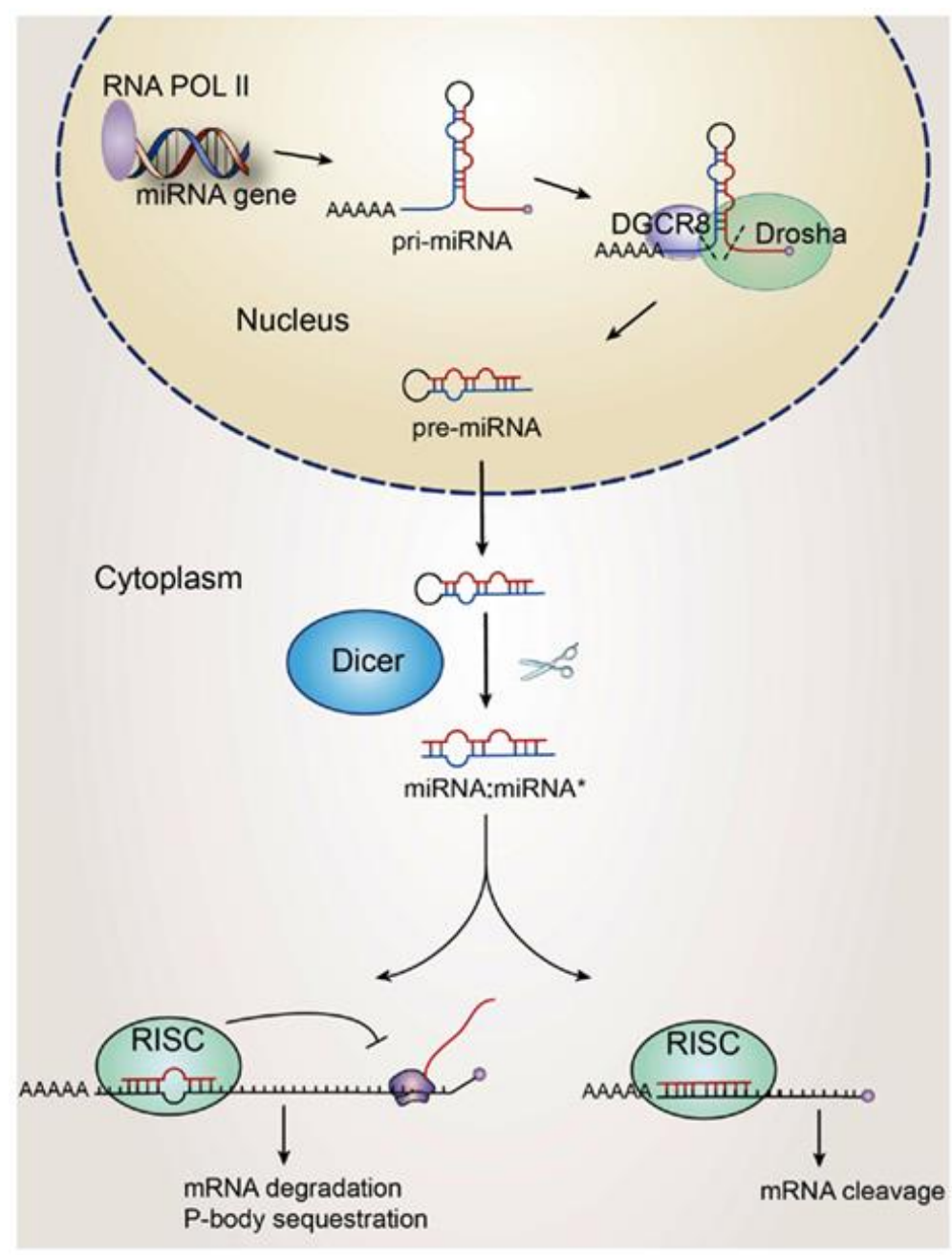

Figura 3 - Biogênese dos microRNAs (via canônica) (Barca-Mayo et al.,2012).

Os microRNAs podem ser classificados em intergênico ou intragênico de acordo com sua localização genômica (Olena e Patton, 2010).

- microRNAs intergenicos: localizam-se entre duas unidades transcricionais, sua expressão é regulada por seus próprios promotores e possuem características semelhantes às unidades transcricionais de genes codificantes de proteínas (Olena e Patton, 2010).

- Os intragênicos localizam-se nas unidades transcricionais e se subdivedem em: a) Intrônicos: localizados na região de um íntron de uma unidade transcricional, geralmente utilizam-se dos mesmos promotores de sua unidade transcricional hospedeira. Uma particularidade desses microRNAs é que a sequencia precursora (pré-microRNA) apresenta o tamanho exato do íntron, após a transcrição e 
processamento de seu RNA hospedeiro, os íntrons removidos irão formar o prémicroRNA. Portanto as etapas iniciais da biogênese não são necessária para esses microRNAs, tornando-os independentes de clivagem pela Drosha (Okamura, 2007). Nessa via não canônica, o miRNA gerado recebe o nome de miRtron. Geralmente sua expressão é similar a do seu gene hospedeiro (Bell et al., 2010). b) Exônicos: possuem frequência baixa ou nula entre as espécies, em homo sapiens correspondem a apenas 5\% do total de microRNAs. Geralmente são encontrados no final de um éxon, estendendose para o inicio do íntron adjacente de um gene não codificador e compartilham os promotores de seu gene hospedeiro (Maselli et al., 2008).

Os microRNAs são frequentemente agrupados (clustering) próximos uns dos outros no genoma, podendo ter origem no mesmo transcrito primário (pri-miRNA) (Griffiths-Jones et al., 2008). Os clusters são descritos como um conjunto de microRNAs hospedados em regiões genômicas próximas umas das outras, com a distância máxima de aproximadamente 10.000 nucleotideos entre cada microRNA membro do cluster (Griffiths-Jones et al., 2008). Geralmente, genes de miRNAs que possuem sequência homologas e produzem transcritos maduros contendo região seed idêntica ou muito semelhante são agrupados em famílias (Ambros et al., 2003).

\subsubsection{Nomenclatura}

A nomenclatura dos microRNAs é baseada em números de identificação sequencial. O prefixo composto por três letras refere-se à espécie, por exemplo, o prefixo "hsa" refere-se à espécie humana (Homo sapiens). Os loci gênicos que codificam microRNAs e os pré-microRNAs são denominados usando o prefixo "mir\#”, enquanto os microRNAs maduros possuem prefixo "miR-\#”. Ambos seguidos de hífen e um número de identificação (Lagos-Quintana et al., 2001; Griffiths-Jones et al., 2008).

Sendo que os loci gênicos devem ser escritos em itálico para diferenciar do prémicroRNA (Ambros et al., 2003).

Alguns genes de microRNAs apresentam cópias parálogas no genoma, quando estes originam sequencias maduras idênticas, acrescenta-se mais um hífem e mais um número “miR-\#-1, miR-\#-2”. Em humano, por exemplo, os genes de hsa-mir-7-1 e hsamir-7-2 encontram-se localizados nos cromossomos 9 e 15, respectivamente e ambos expressam o microRNA maduro com sequência de nucleotídeos idêntica (miRBase). Além disso, os microRNAs com sequências maduras homológas, ou seja, não idênticas 
mas muito similares, usa-se o mesmo número e adiciona-se uma letra minúscula "miR\#a, miR-\#b” (Lagos-Quimtana et al., 2001).

Outra convenção adotada é o uso do sufixo para identificar de qual extremidade do pré-microRNA que se origina a(s) fita(s) de microRNA maduro após a clivagem pela Dicer. Assim usa-se “-3p e 5p” para indicar a origem na porção 3' e 5', respectivamente, do braço precursor (Griffiths-Jones et al., 2008).

\subsubsection{Mecanismos de regulação por microRNAs}

Após a montagem do complexo miRISC, a fita guia do microRNAs irá direcioná-lo até o alvo promovendo a regulação da expressão gênica. A interação miRNA-mRNA é mediada pela sequencia seed (do inglês semente), uma região constituída pelos nucleotídeos da posição 2-8 da extremidade 5' do microRNA e que inicia a hibridização do micorna com o mRNA alvo (Zamore e Haley, 2005). Apesar do grau de complementariedade ser um parâmetro importante, ele não é o único determinante da forma como o complexo miRISC atua, hibridização parcialmente complementar também pode levar a clivagem do mRNA-alvo (Ameres e Zamore, 2013).

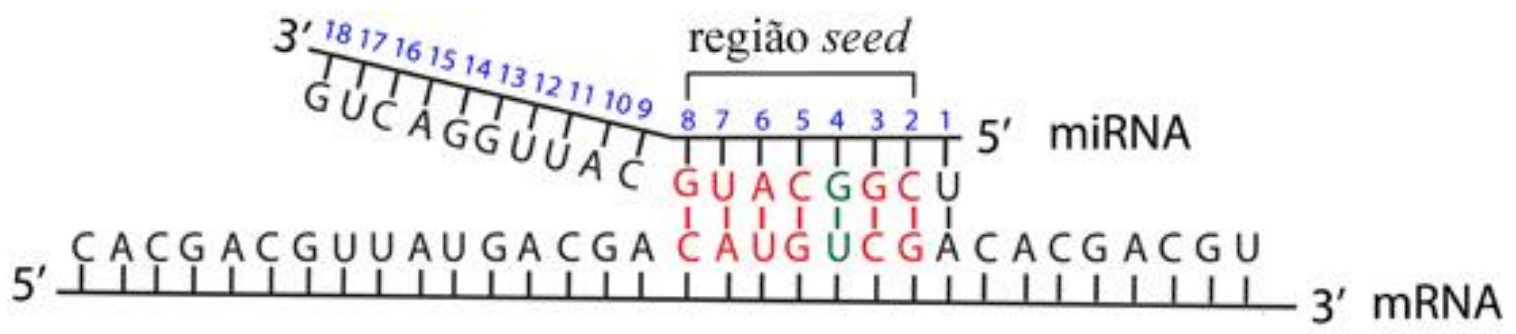

Figura 4 - Esquema da interação entre miR e o mRNA-alvo. Em azul são os nucleotídeos do miR, em vermelho os nucleotídeos responsáveis pelo reconhecimento do mRNA-alvo, chamados de região seed (adaptado de Peterson, 2014)

O mecanismo de inibição da tradução pode ocorrer devido aos seguintes processos: 
- Competição pelo 5' CAP (alguns microRNAs interferem no reconhecimento do 5'CAP, impedindo a montagem do complexo de pré-iniciação da tradução e consequentemente inibe a tradução (Pestova et al., 2001).

- Inibição da montagem dos ribossomos - A AGO2 é capaz de se associar a eIF6 (eucaryotic translation initiation factor 6) impedindo a montagem dos ribossomos e consequentemente a tradução (Chendrimada et al., 2007).

- Deadenilação - alguns microRNAs promovem a deadenilação do mRNA-alvo, o que impede a circularização do mRNA (interação do 5'CAP com a cauda Poli-A) e consequentemente sua tradução (Wakiyama et al., 2007).

- Desmontagem prematura dos ribossomos - (Petersen et al., 2006), redução da velocidade de elongação ou proteólise durante a fase de elongação (Maroney et al., 2006; Nottrott et al., 2006)

A desestabilização do transcrito-alvo e sua consequente clivagem podem ocorrer por dois mecanismos:

- Clivagem do RNA alvo - quando os microRNAs são totalmente complementares ao mRNA-alvo, ativando a atividade slicer de AGOs que clivam um sítio do mRNA-alvo que corresponde aos nucleotídeos 10 e 11 do RNA guia, esse mecanismo ocorre principalmente em plantas (Llave et al.,2002; Palatinik et al., 2003). Os produtos derivados dessa clivagem são rapidamente degradados.

- Deadenilação seguida por retirada do 5'CAP - em alguns casos, a proteína AGO se associa a outras proteínas que promovem a remoção da cauda poli-A e remoção do 5'CAP. Esse evento desestabiliza o mRNA que se torna alvo de exonucleases que o degradam (Behm-Ansmant et al., 2006).

Ademais, os microRNAs podem ainda intensificar a promoção da transcrição. É o caso do let-7i, capaz de interagir com o motivo TATA-box facilitando a montagem do complexo de pré-iniciação da transcrição sobre o promotor do IL-2, resultando numa elevação da produção do transcrito do mesmo (Zhang et al., 2014).

\subsubsection{MicroRNAs e Câncer}

Os microRNAs desempenham um importante papel regulatório em processos biológicos e patológicos. Cerca de $30 \%$ dos mRNAs humanos são regulados por microRNAs (Bartel et al., 2004). Um mRNA pode ser alvo de múltiplos microRNAs, 
enquanto um microRNA pode regular numerosos transcritos de mRNA (Nagadia et al., 2013). Eles estão envolvidos em vários processos biologicos como diferenciação, crescimento, proliferação e apoptose. Processos estes comumente desregulados no câncer, indicando seu envolvimento na carcinogênese. O primeiro estudo que demonstrou a relação de microRNAs e câncer foi em leucemia linfocítica crônica onde verificaram que miR-15 e miR-16 estavam ausentes ou com baixa expressão na maioria dos casos comparados (68\%) ao controle, sugerindo que estavam relacionados a patogênese da leucemia linfocítica crônica (Calin et al., 2002).

No câncer, os microRNAs trabalham como moléculas reguladoras, atuando como oncogenes ou supressores tumorais (Shenouda et al., 2009). A superexpressão de oncomirs em tumores contribuem para oncogênese por inibir genes supressores tumorais e/ou genes que controlam a diferenciação celular ou apoptose, como o P53 que é inibido pelo miR-372/373. Outros oncomirs conhecidos são miR-21, miR-155 e miR17-92 (Nagadia et al., 2013; Zheng et al., 2011; Cervigne et al.,2009). Por outro lado, os microRNAs também podem ser classificados como supressores de tumor, quando sua ação se opõe a oncogênese, por exemplo miR-34a, let-7, miR-143 (Zheng et al., 2011; Kozaki et al.,2008). Os microRNAs são tecido específicos, alguns podem ser oncogênicos em um tipo celular ou tecido e supressor de tumor em outro, dependendo do contexto do tecido e os genes alvos (Zheng et al., 2011). Embora os microRNAs tenham sido bem estudado no contexto da carcinogêne, dentro do contexto de CCP eles ainda estão pouco elucidados (Puram e Rocco; 2015).

Mesmo com todo avanço na área de imagens para diagnóstico e monitoramento das doenças neoplásicas, a análise do tecido tumoral por meio de técnicas invasivas ainda é muito utilizada. Isso ocorre porque o numero de biomarcadores confiáveis em fluidos biológicos ainda é baixo para que seja aplicado na clínica. Nesse sentido, os microRNAs são extremamente promissores, pois estão presentes de forma estável em diversos fluidos corporais como saliva, plasma, soro, urina e outros (Madhavan et al., 2013; Weber et al., 2010). Os microRNAs circulantes estão contidos principalmente dentro de microvesículas, chamadas exossomos, que os protegem de serem degradados por ribonucleases presentes no meio extracelular (Mitchell et al., 2008), tornando-os resistentes a condições desfavoráveis como temperaturas e pHs extremos ou ciclos de congelamento/descongelamento (Chen et al., 2008; Wu et al., 2011). 


\section{5. - Microvesículas}

Identificado inicialmente como um mecanismo pelo qual as células poderiam dispor de proteínas danificadas ou desnecessárias (Fader et al., 2006), as microvesículas derivadas de células agora são vistas como importantes mediadores da comunicação intercelular. Recentemente, o interesse em estudar vesículas extracelulares tem aumentado significantemente. Diferentes categorias de vesículas têm sido descritas, incluindo exossomos, microvesículas, corpos apoptóticos, entre outras (Wurdinger et al., 2012). As distintas características, propriedades e papel funcional de cada subtipo ainda necessitam de mais investigações. Os dois principais subtipos são os exossomos e as microvesículas, distintas na morfologia, características biofísicas (como forma, tamanho e densidade) e biogênese (György et al., 2011) (Figura 5), mas também apresentam características em comum como presença de proteínas do citoesqueleto e fosfatidilserina externalizadas (Cocucci et al., 2009).

Os exossomos são pequenas vesículas formadas por uma bicamada lipídica de aproximadamente 40-100nm de tamanho (Lee et al., 2012; Mathivanan et al., 2012). Um subconjunto de proteínas características contidas nos exossomos, como Alix (Baietti et al., 2012) e Tsg101 (Nabhan et al., 2012) estão associadas com a via endossomal/lisossômica. Sua origem é endocítica, são liberados pela fusão de corpos multivesiculares à membrana plasmática (Simpson et al, 2009, Thery et al, 2002). Inicialmente a membrana celular é internalizada para produzir endossomos. Subsequentemente muitas pequenas vesículas são formadas dentro dos endossomos por partes invaginantes da membrana endossomal. Esses endossomos são chamados de corpos multivesiculares, alguns são destinados aos lisossomos para degradação enquanto outras se fundem á membrana plasmática e liberam as vesículas internas no espaço extracelular, dentre elas estão os exossomos (Gruenberg et al., 2006). Uma vez liberados no espaço extracelular, eles podem ser internalizados pelas células receptoras por mecanismos como endocitose, fagocitose, micropinocitose ou fusão direta entre as membranas lipídicas (Morelli et al., 2004, Feng et al., 2010; Parolini et al., 2009; Fitzner et al., 2011). Os mecanismos de seleção do conteúdo carreado pelos exossomos ainda é pouco compreendido.

As microvesículas (MVs) também são referidas como ectossomas ou micropartículas, elas são maiores que os exossomos variando de 100 a 1000nm de diâmetro. A biogênese das Mvs envolve o brotamento da membrana plasmática para o 
espaço extracelular (Théry et al., 2009), e este processo capta o conteúdo celular citosólico no lúmen formado. A formação das MVs é regulada pela ativação de receptores de superfície celular com subsequente aumento de cálcio intracelular (Kahner et al., 2008). As MVs são mais heterogêneas, sua composição molecular depende do tipo celular e do estado de ativação da célula produtora (Cocucci et al., 2009, Pilzer et al., 2005).

Apesar das diferenças entre exossomos e MVs, a distinção entre elas permanece sutil, não há evidência de uma separação estrita de seus papeis funcionais e nem propriedades estabelecidas ou marcadores moleculares que distinguam claramente essas duas classes de vesículas (Principe et al., 2013). Diante disso a maioria dos estudos não distinguem rigorasamente as duas classes de vesículas, muitas vezes considerando MVs como uma população mista que inclui ambos os tipos de vesículas, tendo em vista que tanto os exossomos quanto as Mvs têm demonstrado serem promissoras na descoberta de biomarcadores do câncer (D'Souza-Schorey et al., 2012).

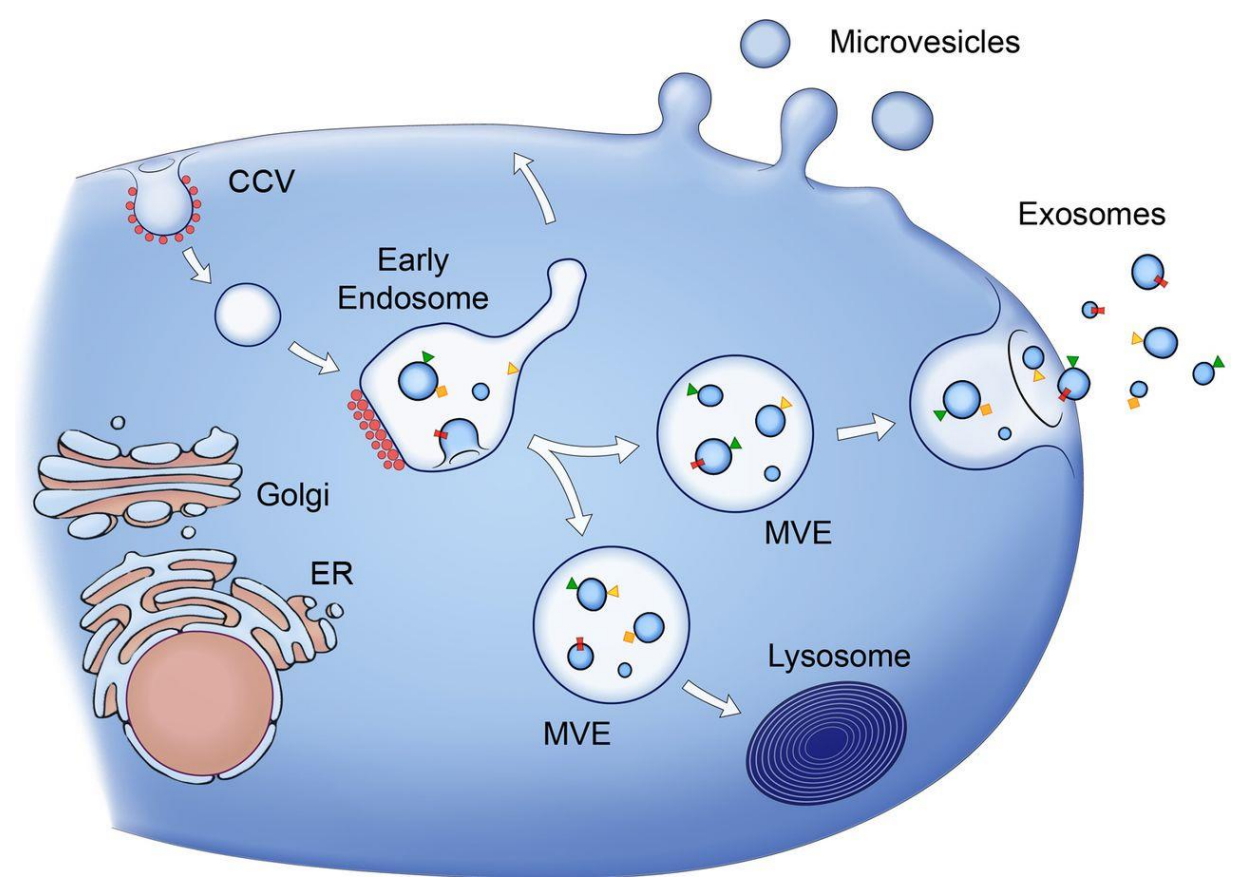

Figura 5 - Biogênese dos exossomos e Microvesículas - Na formação dos exossomos, a membrana plasmática é internalizada para produzir endossomos, pequenas vesículas são formadas dentro dos endossomos formando corpos multivesiculares que se fundem à membrana plasmática liberando os exossomos no meio extracelular. Já as Mvs são formadas pelo brotamento da membrana plasmática para o espaço extracelular. (Raposo et al., 2013). 
A comunicação célula-célula pode ser contato-dependente, onde envolve contato físico, como junções GAP e conecções sinápticas ou pode ser contato-independente, em que não necessita de contato físico como a sinalização endócrina ou mecanismo similar que envolve a transferência de moléculas. Neste contexto as microvesículas participam dessa comunicação contato-independente (Sadowski et al., 2009; Platta et al., 2011). Elas são secretadas por diversos tipos celulares como células epiteliais, linfócitos B e T (McLellan, 2009), mastócitos, células dendríticas (Admyreet al., 2008) e neurônios (Lachenal et al., 2011).

Os componentes protéicos dos exossomos incluem heat shock proteínas (Hsp70, Hsp90), componentes do citoesqueleto como actina e tubulina, tetraspaminas (CD9, CD81 e CD63) e outas proteínas (Thery et al., 2002). Exossomos carream em seu interior todos os constituintes moleculares conhecidos de uma célula: proteínas, lipídeos, microRNAs, mRNAs e DNA (Ratajczak et al., 2006; Valadi et al., 2007; Kahlert at al., 2014). Estudos recentes tem destacado a importância do conteúdo molecular que os exossomos carream, a presença de ácidos nucléicos em exossomos derivados de células neoplásicas é uma fonte de biomarcadores para diversos tipos de câncer, como glioblastoma, bexiga, fígado, colorretal, pulmão, próstata e outros (Skog et al., 2008; Munagala et al., 2016; Tovar et al., 2016; Mohankumar et al.,2016; Nilsson et al., 2009; Long et al., 2015). Esses exossomos podem conter DNA dupla-fita (Kahler et al., 2014; Thakur et al., 2014) e mutações específicas do tumor que podem ser detectadas nos exossomos circulantes dos pacientes com câncer (Munagala et al., 2016; Lázaro et al., 2014; Skog et al., 2008). Em estudos recentes tem sido extensivamente reportado a presença de microRNAs nos exossomos, como fonte para diagnóstico e monitoramento da progressão neoplásica (Taylor et al., 2010; Corcoran et al., 2011; Munagala et al., 2016; Zhang et al., 2015). Os perfis de expressão gênica encontrado nos exossomos nem sempre correspondem a composição das células de origem, sugerindo que existe uma seleção dos mRNAs e microRNAs que serão carreados pelos exossomos. A transferência de microRNAs via exossomos permite rápida alteração na expressão gênica da célula receptora (Mittelbrunn et al., 2011; Ramachandran et al., 2012).

Pela transferência de biomoléculas (lipídios, proteínas, DNA, microRNAs e mRNAs) para células de sítios locais e distantes, os exossomos podem alterar vias de sinalização, perfis moleculares e regulação gênica da célula receptora, podendo assim 
moldar o microambiente durante o desenvolvimento e progressão tumoral (Peinado et al., 2011; Roberson et al., 2010; Mathivanan et al., 2010; Valadi et al., 2007; Subra et al., 2010; Stoorvogel et al., 2002; Ge et al., 2012). No microambiente tumoral os exossomos estão envolvidos na promoção do crescimento do câncer primário, angiogênese, ativação de fibroblastos estromais, arquitetura da matriz extracelular tumoral, supressão da resposta imune do hospedeiro e geração de nicho pré-metastático (revisado por Ge et al., 2012).

As microvesículas e exossomos são encontradas em muitos fluidos corporais como plasma (Grant et al., 2011), urina (Pisitkun et al., 2004), fluido cerebroespinhal (Street et al., 2012), saliva (Gonzalez-Begne et al., 2009; Ogawa et al., 2008), fluido sinovial (Skriner et al., 2006) entre outros. Há evidências que a liberação de exossomos nos fluidos corporais esta aumentada em vários tipos de tumores, como ovário, glioblastoma, melanomas, pancreático entre outros (Graves et al., 2004; Skog et al., 2008; Peinado et al., 2012; Arscott et al., 2011). A sua relativa estabilidade em fluidos corporais lhes confere um grande interesse como fonte de biomarcadores para a detecção e monitoramento do câncer (D’Souza-Schorey et al., 2012).

\section{6. - Saliva}

A saliva é um fluido oral produzido pelas glândulas salivares, composta de mais de $99 \%$ de água e menos de $1 \%$ de proteínas, eletrólitos, e outros componentes de baixo peso molecular (Soini et al., 2010). Secreções salivares são misturas complexas de proteínas, lipídeos, carboidratos e íons, originados de três pares de glândulas salivares maiores, parótida, submandibular e sublingual; e mais de 600 glândulas salivares menores localizadas em toda cavidade oral (Lamy et al., 2012). As parótidas produzem secreções serosas enquanto as glândulas submandibular e lingual produzem secreções mistas que serão serosas e mucinosas. A combinação dessas secreções é chamada saliva total e incluem proteínas ( $\alpha$-amilase, mucinas, histatinas, cistatinas, etc), microorganismos, debris celulares, fluidos gengivais e componentes séricos (Chiappin et al., 2007).

A saliva pode ser coletada por meios não invasivos, eliminando assim o desconforto e dor que podem ser associados com a coleta de alguns materiais biológicos (Liu J. et al, 2012). Ela pode ser coletada sem estímulo onde o paciente cospe em um 
frasco graduado ou pode ser coletada com o auxílio de um estimulante como o ácido cítrico ou indução do reflexo mastigatório (Chiappin et al., 2007). A coleta sem estímulo gera um volume até três vezes menor que a coleta estimulada, mas tem a vantagem de refletir com maior acurácia o estado de equilíbrio com a condição clínica sistêmica e ser menos influenciada pela função da glândula salivar. $\mathrm{O}$ uso de agentes estimulantes pode alterar a composição da saliva $(\mathrm{pH})$ e aumentar a produção de água diluindo assim os componentes de interesse (Yan et al., 2009). Além disso, é uma fonte de material biológico em pacientes não operáveis, sendo uma opção atraente como ferramenta clínica nos casos de carcinoma epidermoide de cavidade oral e orofaringe. Como ela fica em contato direto com a lesão pré-maligna ou maligna, pode conter proteínas e outras substâncias expressas localmente e que podem ser utilizadas como biomarcadores de doença, pois podem ser estreitamente relacionados às condições de saúde do indivíduo (Liu et al, 2012).

Em suma, os pacientes portadores de carcinoma epidermoide (CE) de cavidade oral e orofaringe localmente avançado e irressecável, tratados com QRT concomitante a cisplatina apresentam taxas de sobrevida insatisfatórias, sendo a resistência a QRT um obstáculo à eficácia do tratamento. Como os microRNAs possuem papel diferencial na resistência aos tratamentos quimioterápicos e estão presentes com grande estabilidade na saliva, pretendemos através deste estudo identificar microRNAs presentes na saliva de pacientes com CEC de cavidade oral e orofaringe associados ao benefício do tratamento com QRT. 


\section{OBJETIVOS:}

\section{Objetivo geral:}

Identificar microRNAs relacionados a resposta a longo prazo ao tratamento quimiorradioterapico a base de cisplatina em pacientes com carcinoma epidermoide de cavidade oral e orofaringe localmente avançados, irressecáveis.

\section{Objetivos específicos:}

1- Padronizar o processamento da saliva.

2- Fazer uma revisão sistemática para identificar microRNAs e mRNAs relacionados ao tratamento com cisplatina e/ou radioterapia. Identificar os principais microRNAs associados ao benefício ao tratamento através de análises in silico.

3- Determinar a expressão dos microRNAs escolhidos na saliva de indivíduos saudáveis e de pacientes portadores de carcinoma epidermoide de cavidade oral e orofaringe localmente avançados e irressecáveis, em diferentes situações clínicas:

Grupo 0: Indivíduos saudáveis.

Grupo 1: Pacientes portadores de doença localmente avançada e irressecável sem tratamento prévio,

Grupo 2: Pacientes que apresentam falha de tratamento (recidiva ou progressão da doença) pós QRT definitiva;

Grupo 3: Pacientes livres de doença há pelo menos dois anos pós QRT definitiva.

4- Correlacionar a expressão dos microRNAs com os dados de falha do tratamento, sobrevida e parâmetros clínicos.

5- Verificar se os microRNAs circulantes associados ao benefício a QRT estão contidos dentro de microvesículas ou circulando livres na saliva. 


\section{MATERIAIS E MÉTODOS}

\subsection{Casuística}

Realizamos um estudo exploratório transversal visando identificar microRNAs presentes na saliva de pacientes com CEC de cavidade oral e orofaringe associados a resposta a longo prazo do tratamento com QRT a base de cisplatina.

Incluimos ao todo 28 voluntários sadios e 70 pacientes com o referido carcinoma localmente avançado e irressecável, assim definidos pela equipe de cirurgia de cabeça de pescoço e encaminhados ao serviço de oncologia clínica, ambos os serviços do ICESP, para tratamento padronizado com QRT a base de cisplatina. Tanto a avaliação cirúrgica quanto a clínica são independentes desta pesquisa.

Os pacientes incluídos compreendem três situações clínicas diferentes que representam a progressão da doença e possíveis respostas ao tratamento:

Grupo 1 (G1) - pacientes portadores de doença localmente avançada e irressecável sem tratamento prévio com indicação de QRT com intuito curativo

Grupo 2 (G2) - pacientes com falha de tratamento (recidiva ou progressão da doença) pós QRT definitiva

Grupo 3 (G3) - pacientes sem evidência de doença há pelo menos 2 anos pós QRT definitiva.

Grupo Controle (G0) - voluntários sadios sem diagnóstico prévio de neoplasias.

O desenho transversal permite a coleta de material em tempo hábil, em comparação ao estudo longitudinal. Todos os pacientes foram acompanhados na rotina ambulatorial o que permitiu fazermos correlação dos valores de expressão dos microRNAs com os dados clínicos de resposta ao tratamento do "Grupo 1".

Os pacientes foram tratados no Instituto do Câncer do Estado de São Paulo (ICESP), Grupo de Oncologia Torácica e Tumores de Cabeça e Pescoço do serviço de oncologia clínica. Todos os pacientes e voluntários sadios foram informados sobre os objetivos do presente estudo e quando concordaram em participar assinaram o Termo de Consentimento Livre e Esclarecido (TCLE). Esse projeto foi aprovado pelo Comitê de Ética em Pesquisa da Faculdade de Medicina com o número 390/12.

As amostras foram identificadas por números arábicos para manter o anonimato dos pacientes. No entanto, não haverá dissociação irreversível dos dados. O material 
será armazenado por cinco anos e se houver interesse em mantê-lo por um período maior, será solicitada aprovação do Comitê de Ética e Pesquisa (CEP).

Enfatizamos que o presente estudo não implica em mudança das rotinas de indicação das várias modalidades de tratamento (cirurgia, radioterapia, quimioterapia e quimiorradioterapia) e nem do protocolo de tratamento dos pacientes do ICESP.

\subsection{Coleta e processamento das amostras}

Antes de iniciar a coleta os pacientes fizeram um bochecho com água deionizada por cerca de 30segundos para realizar a higienização da cavidade oral. Em seguida foram orientados a sentar confortavelmente para iniciar a coleta não estimulada da saliva, ou seja, à medida que a saliva acumulava no assoalho da boca eles cuspiam em um tubo graduado (Falcon de 50mL) até a obtenção de aproximadamente $3 \mathrm{~mL}$ de saliva. Após a coleta as amostras foram transportadas em gelo para o laboratório, onde foram processadas dentro de no máximo 1 hora para preservar a qualidade do material.

A amostra foi processada com intuito de obtermos três frações: saliva livre de células (SLC), concentrado de microvesículas (Mvs) e sobrenadante livre de microvesículas (SLMvs ).

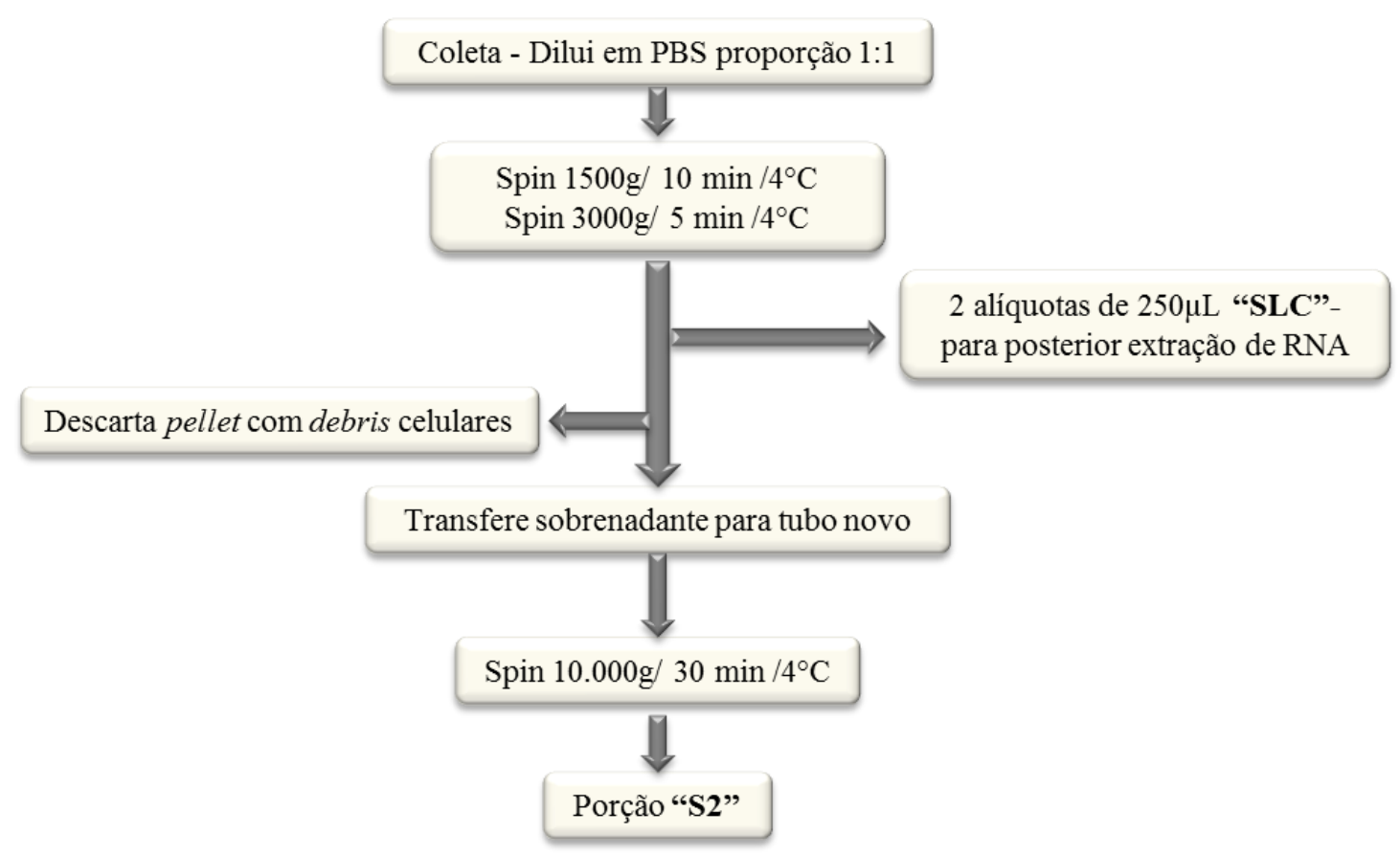

Figura 6 - Fluxograma com a descrição do processamento da saliva para obter: saliva livre de células (SLC) e saliva livre de debris para posterior ultracentrifugação (S2). 


\section{$\underline{\text { Saliva Livre de Células (SLC) }}$}

Primeiramente a saliva foi diluída com PBS 1X na proporção 1:1 com intuito de reduzir a viscosidade do material e permitir seu manuseio. Em seguida a amostra foi submetida a uma centrifugação de $1500 \mathrm{~g}$ por $10 \mathrm{~min}$ a $4^{\circ} \mathrm{C}$ para remoção de células. $\mathrm{O}$ pellet de células foi descartado e o sobrenadante foi então transferido para um microtubo novo e novamente submetido à centrifugação de $3.000 \mathrm{~g}$ por 5 minutos a $4^{\circ} \mathrm{C}$ para remoção de restos celulares. Posteriormente foram retiradas duas alíquotas de $250 \mu \mathrm{L}$ deste sobrenadante, que corresponde a saliva livre de células (SLC), e transferidas para um tubo novo que foi armazenado a $-80^{\circ} \mathrm{C}$ para posterior extração de RNA.

O pellet foi descartado e o restante do sobrenadante foi submetido à uma centrifugação a $10.000 \mathrm{~g}$ por $30 \mathrm{~min}$ a $4^{\circ} \mathrm{C}$, o pellet foi descartado e o sobrenadante transferido para um tubo novo (“S2”) para posterior ultracentrifugação. Em ambos os tubos, SLC e S2, foi adicionado $80 \mathrm{U}$ de RNAse out $(40 \mathrm{U} / \mu \mathrm{L})$ para cada $1 \mathrm{~mL}$ de saliva diluída. Em seguida as amostras foram armazenadas a $-80^{\circ} \mathrm{C}$ até o momento dos experimentos.

\subsection{Separacão de Microvesículas}

As microvesículas foram isoladas por dois métodos diferentes: ultracentrifugação e ExoQuick (System Biosciences).

\section{Ultracentrifugação}

Para isolar microvesículas por ultracentrifugação, tanto as amostras de saliva quanto o PBS utilizado foram filtrados com o auxílio de um filtro de seringa de $0,2 \mu \mathrm{m}$.

Inicialmente $1 \mathrm{~mL}$ da porção "S2" da saliva foi filtrado em filtro $0,2 \mu \mathrm{m} \mathrm{e}$ transferido para um tubo específico de ultracentrifugação, em seguida cerca de $9 \mathrm{~mL}$ de PBS 1x foi filtrado no mesmo filtro da respectiva amostra afim de completar o volume do tubo de ultracentrifugação. Em seguida as amostras foram submetidas a uma

ultracentrifugação de $100.000 \mathrm{~g}$ por 90 minutos a $4^{\circ} \mathrm{C}$ no rotor SW-41Ti (Beckman Coulter e Beckman Optimaym XL-100K, Ultracentrifuge, USA). O sobrenadante livre de Mvs resultante da ultracentrifugação foi armazenado em um tubo novo ("SLMvs") para posterior extração de RNA total e o pellet resultante da ultracentrifugação ("Mvs"), enriquecido em Mvs, foi ressuspendido em 100 $\mu$ L de PBS 1X filtrado para posterior 
extração de RNA total e caracterização das microvesículas, ambas as porções foram armazenados a $-80^{\circ} \mathrm{C}$ até o momento dos experimentos.

\section{Exoquick}

O ExoQuick (System Byosistems) é um reagente de precipitação de exossomos que permite isolar exossomos de fluidos biológicos sem necessidade de usar ultracentrífuga, padronizado para soro e fluido ascitico. Para isolar exossomos de saliva seguimos um protocolo modificado para saliva (Zlotogorski-Hurvitz et al., 2014).

Transferi para um tubo novo $200 \mu \mathrm{L}$ de saliva e $100 \mu \mathrm{L}$ de exoquick. A mistura foi homogeneizada por inversão seguida de incubação por $17 \mathrm{hs} \mathrm{a} 4^{\circ} \mathrm{C}$. Posteriormente a amostra foi submetida a uma centrifugação de $1500 \mathrm{~g}$ por $15 \mathrm{~min}$ a $4^{\circ} \mathrm{C}$. O sobrenadante foi transferido para um tubo novo e o tubo com o pellet de exossomos foi submetido a uma nova centrifugação a $1500 \mathrm{~g}$ por $5 \mathrm{~min}$ a $4^{\circ} \mathrm{C}$ para remover qualquer traço do sobrenadante. $\mathrm{O}$ pellet foi ressuspendido em $20 \mu \mathrm{L}$ de água nucleae free e tanto o pellet quanto o sobrenadante foram armazenados a $-80^{\circ} \mathrm{C}$ para posterior extração de RNA.

\subsection{Extração de RNA total}

\section{-Saliva Livre de Células (SLC)}

As extrações do RNA total foram realizadas com um kit específico para extração de RNA total de fluidos biológicos, o miRCURY $Y^{T M} R N A$ isolation Kit-Biofluids, Exiqon.

Em um tubo RNAse free foram adicionados $200 \mu 1$ da porção "SLC" da saliva e $10 \mu 1$ de proteinase $K(20 \mathrm{mg} / \mathrm{mL})$. Essa mistura foi incubada a $37^{\circ} \mathrm{C}$ por $10 \mathrm{~min}$. Em seguida foram adicionados $60 \mu 1$ de Lysis solution $B F, 1 \mu \mathrm{L}$ de RNA Spike-in template e $1,25 \mu \mathrm{L}$ de $\operatorname{MS} 2(0,8 \mu \mathrm{g} / \mu \mathrm{L}$ - Roche). Essa mistura foi agitada com auxílio do vórtex por 5 seg e incubado por 3 min à temperatura ambiente (TA). A esse lisado foram adicionados $20 \mu 1$ de protein precipitation solution $B F$, a mistura foi agitada por 5 seg e incubada por $1 \mathrm{~min}$ à $\mathrm{TA}$, seguida por uma centrifugação de $11.000 \mathrm{~g}$ por $3 \mathrm{~min}$. $\mathrm{O}$ sobrenadante foi transferido para um tubo novo onde foram adicionados $270 \mu 1$ de isopropanol, a mistura foi agitada por $5 \mathrm{seg}$.

Após a montagem da mini spin column BF em um tubo de coleta, a amostra foi transferida para coluna seguida de uma incubação de 2 min à TA e centrifugação a 
$11.000 \mathrm{~g}$ por $30 \mathrm{seg}$. O filtrado foi descartado e a coluna foi remontada no mesmo tubo. O RNA fica retido na resina da coluna.

Foram adicionados $700 \mu \mathrm{l}$ de wash solution $2 B F$ na coluna e submetido a uma centrifugação a $11.000 \mathrm{~g}$ por $30 \mathrm{seg}$. O filtrado foi descartado, a coluna remontada e então adicionados $250 \mu 1$ de wash solution $2 B F$ na coluna, seguido por uma centrifugação de $11.000 \mathrm{~g}$ por $2 \mathrm{~min}$. Posteriormente foram adicionados $50 \mu \mathrm{L}$ de $r D N A s e$ diretamente na membrana de resina e foi incubado por 15min à TA. Após esse tempo, foram adicionados $100 \mu 1$ de wash solution $1 B F$ na coluna e em seguida submetido a uma centrifugação de $11.000 \mathrm{~g}$ por $30 \mathrm{seg}$. O filtrado foi descartado e a coluna remontada para repetir os passos de lavagem anterior com $700 \mu 1$ e $250 \mu 1$ de Wash solution $2 B F$.

Posteriormente a coluna foi transferida para um tubo novo e foram adicionados $25 \mu 1$ de água RNase free diretamente na resina da coluna. A amostra foi incubada por 1 min à TA e submetida a uma centrifugação a $11.000 \mathrm{~g}$ por $1 \mathrm{~min}$, adicionamos mais $25 \mu 1$ de água RNase free na coluna que continuou montada no mesmo tubo, seguido novamente da incubação por $1 \mathrm{~min}$ a TA e centrifugação a $11.000 \mathrm{~g}$ por $1 \mathrm{~min}$. As amostras de RNA total foram estocadas a $-70^{\circ} \mathrm{C}$.

\section{- Pellet de Microvesículas (Mvs)}

Para extração de RNA total das Mvs partimos de $20 \mu \mathrm{L}$ do pellet ressuspendido tanto para os exossomos obtidos pelo exoquick quanto pelos obtidos por ultracentrifugação (exossomo de $1 \mathrm{~mL}$ de saliva foi ressuspendido em $100 \mu \mathrm{L}$ de PBS $20 \mu \mathrm{L}$ do pellet ressuspendido corresponde a $200 \mu \mathrm{L}$ de saliva total). Aos $20 \mu \mathrm{L}$ adicionamos $180 \mu \mathrm{L}$ de água $R N A$ se free para completar o volume recomendado pelo kit e prosseguimos conforme o protocolo do fabricante, descrito anteriormente para extração de RNA em saliva livre de células.

\section{-Sobrenadante Livre de Microvesículas (SLMvs)}

Para extração de RNA da porção "SLMvs" obtida pela ultracentrifugação, foi preciso reduzir o volume do sobrenadante (aproximadamente $9 \mathrm{~mL}$ ) com o auxílio do equipamento SpeedVac. O volume foi reduzido para $1 \mathrm{~mL}$ e deste foram retirados $200 \mu \mathrm{L}$ para extração de RNA total. Todo o sobrenadante (SLMv) obtido do processamento com o Exoquick também foi utilizado para extração de RNA conforme o protocolo do fabricante, descrito anteriormente para extração de RNA em saliva livre de células. 


\subsection{Revisão da literatura e escolha dos microRNAs de interesse}

Para seleção dos microRNAs realizamos uma revisão da literatura de trabalhos publicados no banco de dados Pubmed. Nesta etapa, buscamos estudos que associavam mRNAs e/ou microRNAs à resposta ao tratamento com cisplatina e/ou radioterapia. Foram realizadas diversas buscas no Pubmed com termos específicos, mas com certa abrangência para garantir que não perdêssemos artigo de relevância.

Os termos utilizados foram:

- (pharyngeal neoplasm[MeSH Terms] OR mouth neoplasm[MeSH Terms] AND tumor markers[MeSH Terms] AND (prognosis[MeSH Terms] OR response)

- microRNA AND (pharyngeal neoplasm OR mouth neoplasm)

-microRNA AND (cisplatin OR radiotherapy OR chemoradiotherapy)

- microRNA AND neck carcinoma

A última atualização das buscas foi realizada no dia 18/02/2014 e foram utilizados filtros para espécie humana e publicações nos últimos cinco anos.

Foram incluídos para posterior análise os artigos que correlacionavam expressão de microRNA, RNA ou proteína a tratamento com cisplatina e/ou radioterapia em pacientes com câncer ou linhagens celulares transformadas. Também foram incluídos trabalhos que avaliaram marcadores prognósticos em pacientes com CCP tratados com quimio e/ou radioterapia.

Foram excluídos trabalhos escritos em outros idiomas que não o inglês (alemão, chinês, japonês, húngaro, polonês) e trabalhos que avaliaram tratamento em tumores muito diferentes de CCP como glioma, leucemia, osteossarcoma e tumores em bexiga, testículo, pâncreas, fígado, carcinomas glandulares, carcinoma de nasofaringe que estivessem associados à EBV (Vírus Epstein-Barr) e trabalhos que analisaram linhagens germinativas. Também foram excluídos os trabalhos em CCP que não avaliaram tratamento ou que avaliaram marcador prognóstico em casuística composta por pacientes tratados exclusivamente com cirurgia.

Os trabalhos foram detalhados em tabela onde foram transcritas as seguintes informações: tipo de carcinoma, tratamento (quimio e/ou radioterapia), moléculas estudadas (microRNA, mRNA ou proteína), nível de expressão da molécula (up ou down-regulada), moléculas validadas e a associação encontrada com o tratamento a base de cisplatina e/ou radioterapia e sobrevida livre de doença ou sobrevida global. Os 
estudos que realizaram perfis de expressão gênica tiveram anotados na tabela todas as moléculas diferencialmente expressas e não apenas as validadas, visto que a escolha das moléculas para validação muitas vezes é direcionada pela literatura.

Em posse dessa lista prévia de moléculas realizamos algumas análises in sílico através do software IPA (Ingenuity Pathway Analysis - Qiagen http://www.ingenuity.com/products) para identificar microRNAs para serem avaliados neste estudo.

\subsection{RT-qPCR (Transcrição Reversa-Reação em Cadeia da Polimerase quantitativa)}

A determinação da expressão dos miRNAs foi feita pelo kit miRCURY LNA ${ }^{\mathrm{TM}}$ universal RT microRNA PCR. A partir do RNA total realizamos a transcrição reversa de todos os microRNAs na mesma reação. Uma cauda poli-A é adicionada aos microRNAs maduros e a fita de cDNA é sintetizada utilizando um iniciador poli-T. Os moldes de cDNA são então amplificados usando iniciadores aprimorados com $L N A^{T M}$, específicos para o microRNA de interesse. A detecção da reação é realizada através do SYBR Green, uma molécula fluorescente que ao intercalar-se à dupla fita de DNA, emite fluorescência possibilitando a quantificação do total de moléculas de DNA produzidas a cada ciclo da reação (Figura 7).

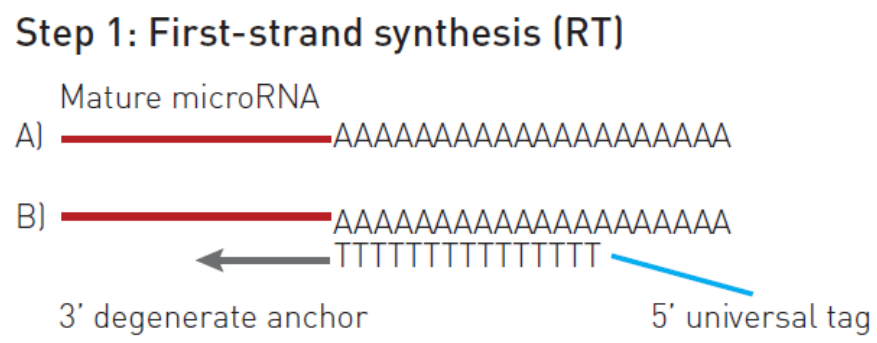

Step 2: Real-time PCR amplification

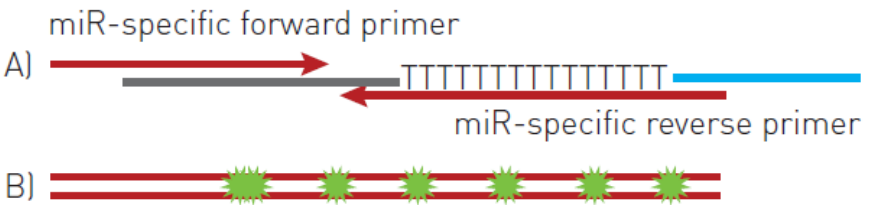

Figura 7 - Desenho esquemático do sistema miRCURY LNA. 
Fizemos duas reações de RT para cada amostra e as misturamos ao final, conforme recomendado pelo fabricante do kit a fim de minimizar possíveis variações da reação de RT. Todas as etapas desse procedimento foram realizadas no gelo. Cada reação tem volume final de $10 \mu \mathrm{L}$. Em um tubo foi preparada uma mistura RT contendo para cada amostra: $2 \mu \mathrm{L}$ de reaction buffer $(5 \mathrm{x}), 1 \mu \mathrm{L}$ de enzyme mix $(10 \mathrm{x}), 1 \mu \mathrm{L}$ de água nuclease free. A mistura foi homogeneizada seguida por uma rápida centrifugação à velocidade máxima de uma minicentrifuga. Para cada reação foram adicionados $4 \mu \mathrm{L}$ dessa mistura e $6 \mu \mathrm{L}$ de amostra. A reação foi transferida para um termociclador. As condições da reação compreendem uma etapa a $42^{\circ} \mathrm{C}$ por $60 \mathrm{~min}, 95^{\circ} \mathrm{C}$ por $5 \mathrm{~min}$ para inativação da enzima transcriptase reversa e $4^{\circ} \mathrm{C}$ até o momento em que os tubos forem retirados do termociclador. As amostras de cDNA foram armazenadas a $-20^{\circ} \mathrm{C}$ até a realização da qPCR.

$\mathrm{Na}$ etapa de qPCR foram realizados ensaios individuais para os microRNAs de interesse: UniSp6 (Spike-in control), miR-16-5p, U6snRNA miR-15a-5p miR-21-5p, miR-23a-3p, miR-125b-5p, miR-142-3p, miR-200b-3p, miR-296-5p e miR-503-5p.

As amostras de cDNA foram diluídas 40x e as reações foram realizadas em triplicatas. Em um tubo foi preparado um mix contendo para cada amostra; $5 \mu \mathrm{L}$ de $S Y B r$ Green máster mix (2x), 0,8 $\mu \mathrm{L}$ do PCR primer mix para o miR-142-3p e $1 \mu \mathrm{L}$ de $P C R$ primer mix para os demais micros, $0,04 \mu \mathrm{L}$ de $\operatorname{ROX}(25 \mu \mathrm{M})$. Essa mistura foi homogeneizada e posteriormente foi aplicado $6 \mu \mathrm{L}$ em cada poço da placa para PCR seguido da adição de $4 \mu \mathrm{L}$ do cDNA diluído 40x. A placa foi submetida a uma rápida centrifugação à velocidade máxima e colocada no aparelho Real Time PCR 7900 (Applied Biosystems). O programa da reação inclui um ciclo de $95^{\circ} \mathrm{C}$ por $10 \mathrm{~min}$ seguido por 40 ciclos de desnaturação a $95^{\circ} \mathrm{C}$ por 10 seg e hibridização a $60^{\circ} \mathrm{C}$ por 1 min.

Ao final foi realizada a curva de desnaturação (melting) para checar a especificidade da reação. Nessa curva analisa-se a fluorescência da amostra em relação ao aumento contínuo da temperatura, o que possibilita analisar a temperatura de desnaturação de cada fragmento amplificado. Todas as reações mostraram um pico único de fluorescência indicando que as reações foram específicas.

\subsection{Cálculo de Expressão Gênica}

O Cicle Treshould $(\mathrm{Ct})$ é definido como o número de ciclos em que a fluorescência gerada na reação de PCR consegue ultrapassar o treshould (um ponto de 
corte definido anteriormente). Para o cálculo de expressão gênica consideramos os valores de Cts até 36, acima disso foi considerado indetectável.

A expressão diferencial dos microRNAs de interesse foi determinada pelo método de quantificação relativa em relação ao microRNA normalizador (miR-16-5p).

Para o cálculo, foi utilizado o modelo matemático $2^{-\Delta \Delta C t}$ proposto por Livak and Schmittgen, 2001, sendo:

$\Delta \Delta \mathrm{Ct}=\Delta \mathrm{Ct}_{\text {amostra alvo }}\left(\mathrm{Ct}_{\text {miR alvo }}-\mathrm{Ct}_{\text {miR normalizador }}\right)-\Delta \mathrm{Ct}_{\text {amostra referência }}\left(\mathrm{Ct}_{\text {miR alvo }}-\mathrm{Ct}_{\text {miR }}\right.$ normalizador).

Nas comparações da expressão do microRNA em saliva livre de células, microvesículas e sobrenadante livre de microvesículas, utilizamos os valores de CT subtraídos do valor 40 (limiar de detecção).

\subsection{Caracterização das microvesículas}

\subsubsection{Identificação de microvesículas por microscopia eletrônica de Transmissão (MET)}

A microscopia eletrônica (MET) foi realizada no Laboratório de Biologia Celular (LIM-59) da Faculdade de Medicina da Universidade de São Paulo - FMUSP.

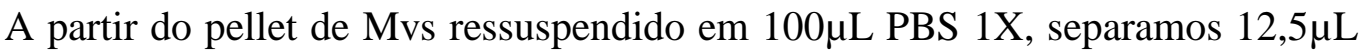
para fazer um pool de amostras para caracterização de microvesículas por ME. Fizemos um pool com 4 amostras de pacientes do grupo 1, grupo 3 e grupo controle, não fizemos pool do grupo 2 (pacientes com recidiva ou progressão da doença) pois este grupo sofre com intensa xerostomia e por isso temos quantidade de amostra muito limitante dos pacientes desse grupo.

Os pools foram transferidos para tubos novos de ultracentrifugação e em seguida as amostras foram submetidas à nova ultracentrifugação a $100.000 \mathrm{~g}$ por $90 \mathrm{~min}$ a $4^{\circ} \mathrm{C}$. Descartamos o sobrenadante e o pellet foi ressuspendido com auxílio de vórtex. Adicionamos $1 \mathrm{~mL}$ de glutaraldeído $2 \%$ ao pellet seguido de incubação por 1 hora a TA para fixação das Mvs. Em seguida o volume do tubo foi novamente completado com PBS 1X e submetido à ultracentrifugação $\left(100.000 \mathrm{~g}, 90 \mathrm{~min}, 4^{\circ} \mathrm{C}\right)$. $\mathrm{O}$ sobrenadante foi descartado e o pellet sofreu etapas de desidratações crescentes com etanol 70\% e 90\%. Em cada etapa, houve incubação de $5 \mathrm{~min}$ com etanol seguida de ultracentrifugação (100.000g, 90min, $\left.4^{\circ} \mathrm{C}\right)$. Em seguida descartamos o sobrenadante e $1 \mathrm{~mL}$ de resina araldite foi depositada no fundo do tubo, ao pellet, e foi levado para estufa a $60^{\circ} \mathrm{C}$ até a 
resina endurecer. Após a formação do bloco, fizemos cortes com espessura de $80 \mathrm{~mm}$. Esses cortes foram incubados com ósmio a TA e no escuro. Após a fixação com ósmio, realizamos a visualização dos cortes no microscópio eletrônico de transmissão.

\subsubsection{Quantificação das microvesículas por NanoSight}

A quantificação de Mvs por tamanho foi realizada através do equipamento NANOSIGHT LM14 no Centro Internacional de Pesquisa do A.C. Camargo Câncer Center.

O Malvern NanoSight LM14 utiliza a tecnologia Nanoparticle Tracking Analysis (NTA) para quantificar a distribuição de partículas por tamanho absoluto de $10 \mathrm{~nm}$ - 1000nm em solução. Essa tecnologia utiliza propriedades de espelhamento de luz e movimento Browniano para obter a distribuição de tamanho e a concentração das partículas em suspensão líquida. As partículas no fluido são iluminadas por um feixe de raio laser que, por conseguinte dispersam a luz que é captada por um microscópio óptico convencional com ampliação de 20x sobre o qual está montada uma câmera (Figura 8). NTA visualiza a luz dispersa pelas partículas individuais no campo de visão do microscópio, a luz dispersa mostra-se como pequenos pontos brilhantes que se deslocam por causa do movimento Browniano, os movimentos das partículas individuais são acompanhados através de três vídeos adquiridos ao longo de um minuto, e a velocidade média de cada partícula é calculada com o software de análise de imagem. Uma vez que a velocidade do movimento Browniano depende da temperatura, viscosidade, e o diâmetro (hidrodinâmico) das partículas, é possível obter o tamanho absoluto das partículas após a calibração do sistema com beads de tamanho e concentrações conhecidos (Harrison et al., 2009). O NTA image analyses software captura o tamanho de muitas partículas simultaneamente e os resultados são apresentados como a distribuição da concentração das partículas por tamanho (Figura 8). 

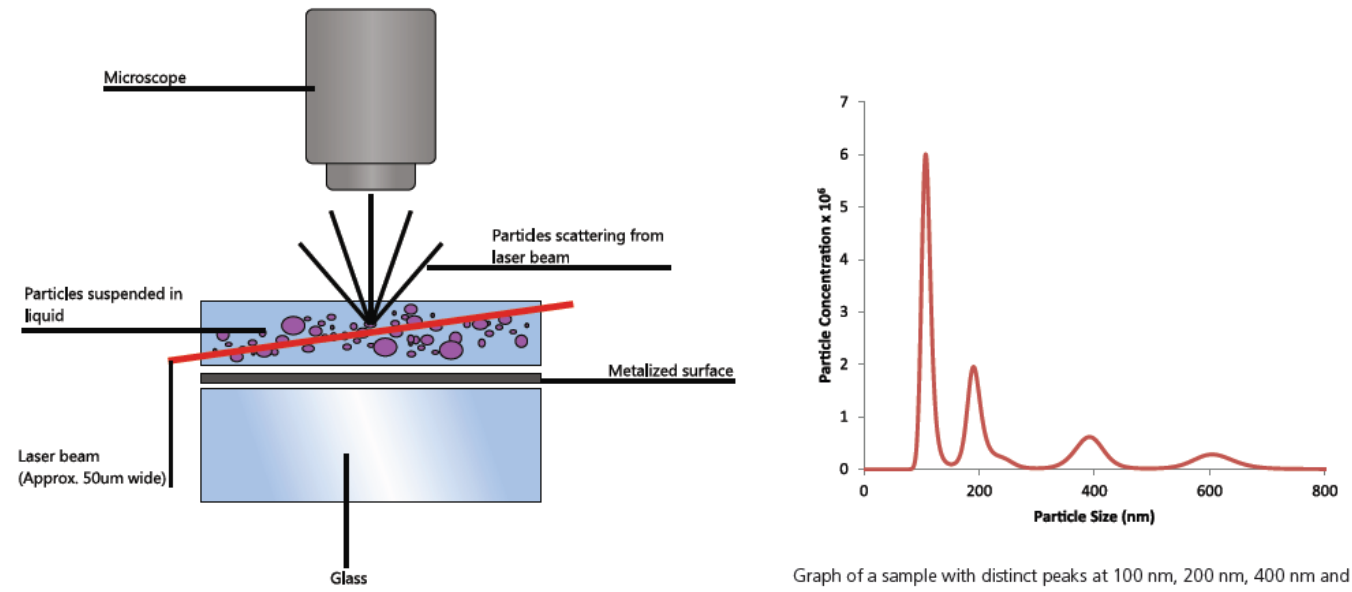

Graph of a sample with distinct peaks at $100 \mathrm{~nm}, 200 \mathrm{~nm}, 400 \mathrm{~nm}$ and $600 \mathrm{~nm}$.

Figura 8 - Sistema Nanosight (Nanosight Range)

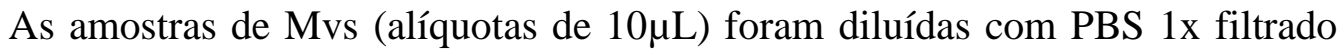
(filtro de $200 \mu \mathrm{m}$ ) a 2500x ou 5000x, de acordo com a concentração das amostras. Antes de iniciar as leituras, a câmara de amostras foi limpa com água Milliq e todo o fluido foi removido com o auxílio de uma seringa que gera uma corrente de ar dentro da câmara.

Com o auxílio de uma seringa, $1 \mathrm{~mL}$ do PBS utilizado para diluir as amostras (Branco) ou $1 \mathrm{~mL}$ de amostra diluída foi injetado bem devagar dentro da câmara de amostras e em seguida foi realizada a quantificação das partículas. Após a leitura, a amostra foi extraída da câmara com o uso de uma seringa e após a leitura de cada amostras, a câmara foi lavada com água Milliq e todo resíduo de água era removido com o auxílio de uma seringa.

Os valores de quantificação foram obtidos fazendo a média da quantificação absoluta (partículas/mL) de 3 leituras da mesma amostra e subtração da leitura do PBS (branco).

\subsubsection{Determinação do antígeno CD63}

A detecção dos exossomos foi feita pelo Exosome ELISA Complete Kit - CD63 detection (System Bioscience). O pellet de exossomo foi ressuspendido em $200 \mu 1$ de Exosome binding buffer, em seguida foi agitado por $15 \mathrm{seg}$ com auxílio de vórtex, incubado por 10min a TA e em seguida colocado em gelo. Após esse processamento, as proteínas exossomais estão prontas para imobilização na placa. Foi feita uma curva de 
diluição seriada com o ExoELISA protein standard. Em seguida, foram adicionados $50 \mu 1$ do preparado de protein standard das amostras nos poços apropriados da placa, que foi incubada a $37^{\circ} \mathrm{C}$ em overnight. Posteriormente, a placa foi invertida e lavada três vezes com $100 \mu 1$ do Wash buffer por $5 \mathrm{~min}$. Foram adicionados $50 \mu 1$ do anticorpo CD63 diluído em cada poço da placa seguindo de incubação a TA por 1 hora com agitação.

Após este tempo, a placa foi lavada três vezes e foram adicionados $50 \mu 1$ do anticorpo secundário em cada poço, com incubação a TA por 1 hora com agitação. A placa foi novamente lavada três vezes e adicionados $50 \mu 1$ do substrato Super-sensitive TMB ELISA, seguido por incubação a TA durante 15-45min com agitação. Posteriormente, adicionamos 50 $\mu 1$ de stop buffer em cada poço para parar a reação e o resultado foi quantificado em espectrofotômetro de placas com leitura de 450nm de absorbância.

A Figura 9 mostra um fluxograma da metodologia adotada nesse estudo. 


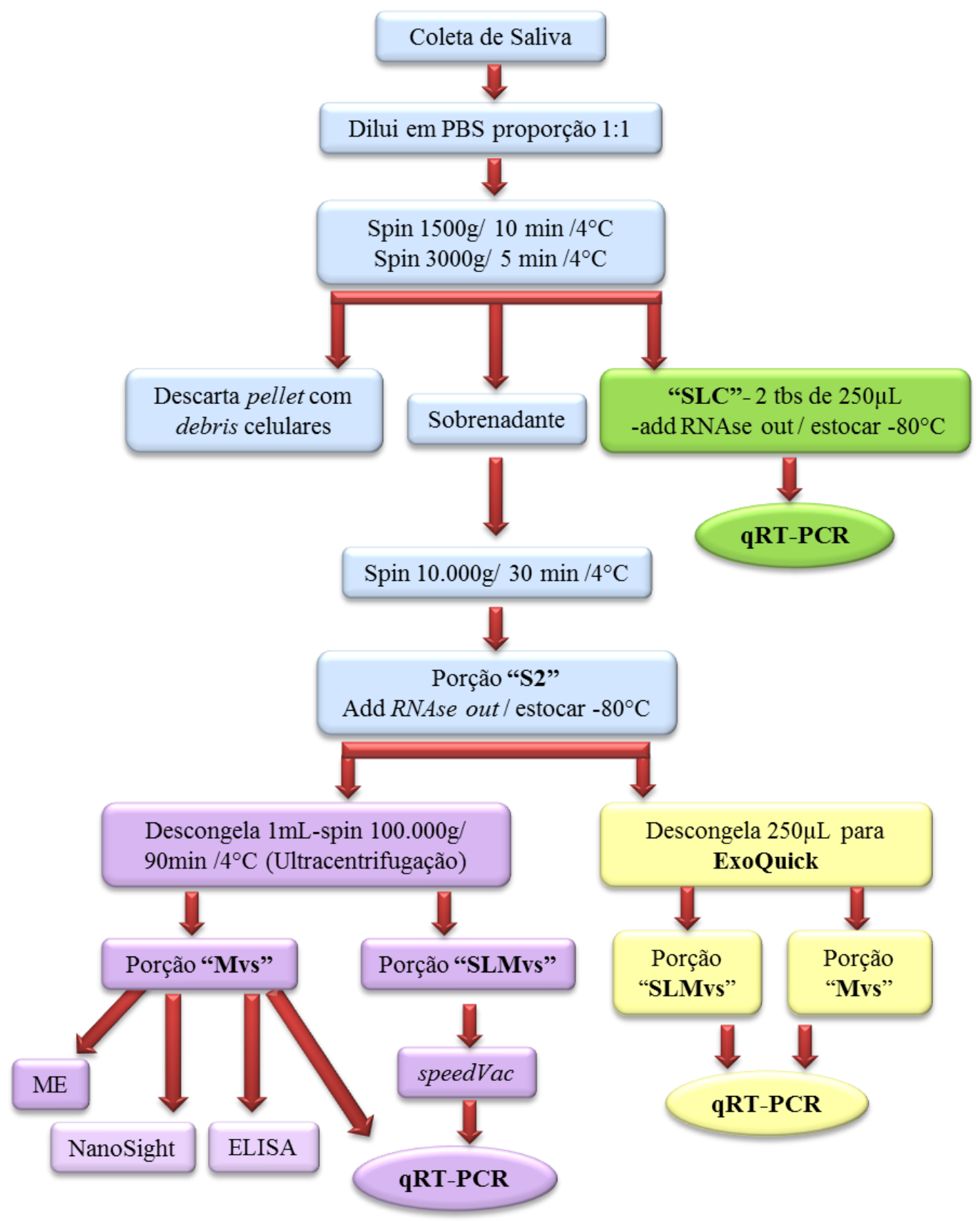

Figura 9 - Fluxograma da metodologia do trabalho. SLC-Saliva Livre de Células, Mvs-Pellet enriquecido de microvesiculas, SLMvs-Sobrenadante Livre de Microvesículas, ME-Microscopia Eletrônica, qRT-PCRTranscrição Reversa-Reação em Cadeia da Polimerase quantitativa

\subsection{Análises dos resultados e considerações estatísticas}

Estimamos a inclusão de 40 voluntários sadios e 120 pacientes no período de dois anos, aproximadamente 40 de cada grupo clínico, citado anteriormente. Em vista 
da natureza exploratória do estudo e da ausência de dados prévios na literatura, não realizamos um cálculo formal de tamanho da amostra.

A sobrevida livre de progressão foi definida como tempo do término do tratamento até a ocorrência da recidiva/progressão da doença ou até a última data de seguimento para os pacientes que não recidivaram e nos casos de pacientes que não responderam ao tratamento esse tempo foi igual a zero. A sobrevida global foi definida como o tempo do término do tratamento até o óbito ou última data de seguimento dos pacientes. A curva ROC foi utilizada para determinação do ponto de corte para categorização dos pacientes de acordo com a expressão dos marcadores. As curvas de sobrevida foram construídas pelo método de Kaplan-Meier e a significância estatística determinada pelo teste Log-Rank. Os grupos de pacientes e o grupo de voluntários sadios foram avaliados separadamente e comparados entre si, já que refletem a progressão da doença.

Os testes estatísticos foram realizados utilizando-se o pacote estatístico SPSS $^{\circledR}$ 20. Para comparação de dados quantitativos, existem dois tipos de testes que podem ser utilizados: os testes paramétricos e os testes não paramétricos. A escolha baseia-se principalmente na distribuição dos dados. Assim, inicialmente, foi utilizado o teste conhecido como Shapiro-Wilk para verificar se os valores de expressão dos microRNAs apresentaram distribuição de acordo com os padrões de normalidade. Como as variáveis não obedeceram a normalidade dos dados a relação entre os valores de expressão dos microRNAs e outros fatores preditivos foram avaliados por testes não paramétricos em todas as análises.

Foram considerados como estatisticamente significativas as diferenças que apresentaram $\mathrm{p}<0,05$, bicaudal. Para comparar se houve diferença significante dos valores de expressão dos microRNAs entre os grupos, foi utilizado teste de KruskalWallis seguido da comparação dois a dois por meio do teste de Mann-Whitney. 


\section{4- RESULTADOS}

\section{1 - Dados Clínicos dos Pacientes}

Para a inclusão dos pacientes, monitoramos as agendas de consultas de todos os médicos assistentes que atendem pacientes com CCP no ICESP. Ao identificar um paciente que correspondia aos critérios de inclusão do estudo, no dia da consulta pedíamos ao médico que nos encaminhasse o paciente logo após o término da consulta. Alguns pacientes também foram abordados nos ambulatórios da odontologia e no setor da quimioterapia. Desta maneira conseguimos fazer a inclusão dos pacientes e coleta da amostra em momentos que os pacientes já teriam que vir ao hospital. Para compor o grupo controle convidamos funcionários de diferentes setores do ICESP e acompanhantes de pacientes da instituição.

Recrutamos ao todo 28 voluntários sadios e 70 pacientes, onde 37 pacientes pertencem ao grupo 1, 9 pacientes pertencem ao grupo 2 e 24 ao grupo 3. Além dos pacientes incluídos, identificamos outros 32 pacientes elegíveis ao estudo, mas que não conseguimos inclui-los por algum dos seguintes motivos: Imposibilidade da coleta devido a intensa xerostomia, efeito colateral da radioterapia (10 pacientes), intenso sangramento tumoral (3 pacientes), por estarem muito debilitados, optamos por não incluir para não causar incômodo ainda maior ao paciente (10 pacientes), recusa em participar do estudo (5 pacientes) e impossibilidade de falar com o paciente (4). Além disso, dois pacientes foram excluídos no estudo por falha de screening (outro sítio tumoral).

A mediana de idade dos pacientes ao diagnóstico foi 56,1 anos, $82,8 \%$ dos pacientes são do sexo masculino sendo que 48,57\% eram fumantes ativos ou haviam parado de fumar há menos de 1 ano no momento da coleta da amostra e 60\% dos pacientes incluído no estudo ainda estavam vivos no dia 30 de maio de 2016.

As informações clínicas dos pacientes seguem especificadas por grupos na Tabela 1 e as informações demográficas do grupo controle seguem na Tabela 2. 
Tabela 1 - Dados clínicos dos pacientes separado por grupo.

\begin{tabular}{|c|c|c|c|}
\hline Classificação & $\begin{array}{c}\text { Grupo } 1 \\
\mathrm{~N}(\%) \\
\end{array}$ & $\begin{array}{c}\text { Grupo } 2 \\
\mathrm{~N}(\%) \\
\end{array}$ & $\begin{array}{c}\text { Grupo } 3 \\
\mathrm{~N}(\%) \\
\end{array}$ \\
\hline \multicolumn{4}{|l|}{ Gênero } \\
\hline Masculino & $31(83,8 \%)$ & $8(88,9 \%)$ & $19(79,2 \%)$ \\
\hline Feminino & $6(16,2 \%)$ & $1(11,1 \%)$ & $5(20,8 \%)$ \\
\hline Idade do diagnóstico & 57,7 anos $(40-71)$ & 56,5 anos $(50-66)$ & 53,8 anos $(42-67)$ \\
\hline \multicolumn{4}{|l|}{ Histórico Familiar } \\
\hline Sim & $17(46 \%)$ & $2(22,2 \%)$ & $12(50 \%)$ \\
\hline Não & $20(54 \%)$ & $7(77,8 \%)$ & $12(50 \%)$ \\
\hline \multicolumn{4}{|l|}{ Tabagismo } \\
\hline Ativo & $23(62,2 \%)$ & $3(33,4 \%)$ & $8(33,3 \%)$ \\
\hline Ex-tabagista & $13(35,1 \%)$ & $6(66,6 \%)$ & $12(50 \%)$ \\
\hline Nunca & $1(2,7 \%)$ & 0 & $3(12,5 \%)$ \\
\hline \multicolumn{4}{|l|}{ Etilismo } \\
\hline Ativo & $14(37,8 \%)$ & $2(22,2 \%)$ & $5(20,8 \%)$ \\
\hline Ex- etilista & $22(59,5 \%)$ & $7(77,8 \%)$ & $17(70,8 \%)$ \\
\hline Nunca & $1(2,7 \%)$ & 0 & $1(4,1 \%)$ \\
\hline Sem informação & 0 & 0 & $1(4,1 \%)$ \\
\hline \multicolumn{4}{|l|}{ Sítio do tumor } \\
\hline Orofaringe & $35(94,6 \%)$ & $9(100 \%)$ & $21(87,5 \%)$ \\
\hline Cavidade Oral & $2(5,4 \%)$ & 0 & $3(12,5 \%)$ \\
\hline \multicolumn{4}{|l|}{ Estadiamento Clínico } \\
\hline 1 & 0 & 0 & 0 \\
\hline 2 & $2(5,4 \%)$ & 0 & $3(12,5 \%)$ \\
\hline 3 & $4(10,9 \%)$ & 0 & $4(16,6 \%)$ \\
\hline 4 & $28(75,7 \%)$ & $9(100 \%)$ & $16(66,7 \%)$ \\
\hline Sem informação & & & $* 1(4,2 \%)$ \\
\hline \multicolumn{4}{|l|}{ Status } \\
\hline Vivo & $21(56,7 \%)$ & $0(0 \%)$ & $21(87,5 \%)$ \\
\hline Morto & $16(43,3)$ & $9(100 \%)$ & $3(12,5 \%)$ \\
\hline \multicolumn{4}{|l|}{ Falha de Tratamento } \\
\hline Sim & $14(37,8 \%)$ & N/A & $3(12,5 \%)$ \\
\hline Não & $15(40,6 \%)$ & N/A & $21(87,5 \%)$ \\
\hline Sem info & $8(21,6)$ & & \\
\hline
\end{tabular}

*Paciente faz seguimento no ICESP, mas fez tratamento QRT em outro hospital, por isso não temos informação do TNM. Histórico Familiar de Câncer - qualquer parente de primeiro grau com diagnóstico de carcinoma de qualquer tipo. Tabagista ativo: tabagista ou ex-tabagista há menos de 1 ano da data da coleta, ex-tabagista: cessou fumo há mais de 1 ano da data da coleta.

Entre os pacientes do grupo 3, temos 1 paciente que nunca fumou e é ex-etilista social e foi diagnosticado com CEC de orofaringe em tonsila aos 42 anos. Foi confirmado pelo método de captura híbrida, a positividade para HPV. Esse método detecta 13 tipos de HPV de alto risco, porém não identifica o tipo específico de HPV. 
Esse método não está incluído no presente estudo, ele foi realizado pelo hospital, não tendo sido realizado nos demais pacientes.

Tabela 2 - Dados demográficos do grupo controle, voluntários sadios.

\begin{tabular}{cc}
\hline \multicolumn{1}{c}{ Classificação } & $\mathbf{N}(\%)$ \\
\hline Gênero & $17(60,7 \%)$ \\
Masculino & $11(39,3 \%)$ \\
Feminino & \\
Mediana da Idade na coleta & 51,45 anos $(33,3-78,45)$ \\
Histórico Familiar de Câncer & \\
Sim & $15(53,6)$ \\
Não & $12(42,8 \%)$ \\
Sem info & $1(3,6 \%)$ \\
Tabagismo & \\
Ativo & $4(14,3 \%)$ \\
Ex-tabagista & $15(53,6 \%)$ \\
Nunca & $9(32,1 \%)$ \\
Etilismo & \\
Etilista Social & $14(50,0 \%)$ \\
Ex- etilista social & $10(35,7 \%)$ \\
Nunca & $3(10,7 \%)$ \\
Sem info & $1(3,6 \%)$ \\
\hline
\end{tabular}

\section{2 - Padronização do processamento da saliva}

Primeiramente foi preciso padronizar o processamento das amostras de saliva. Inicialmente as amostras eram processadas sem nenhuma diluição prévia, porém tínhamos muita dificuldade em separar o sobrenadante dos debris e restos celulares devido à alta viscosidade do material, principalmente nas amostras dos pacientes que sofriam com a xerostomia (boca seca). Testamos então a diluição da amostra com DTT (Ditiotreitol que é utilizado em amostras de escarro), que diminuiu a viscosidade do material e permitiu uma boa separação do sobrenadante e debris. Porém, posteriormente quando fizemos os testes para a determinação dos microRNAs, os mesmos foram indetectáveis nas amostras diluídas com DTT, indicando uma possível interferência desse reagente com a extração ou quantificação de microRNAs pelos kits que utilizamos nesse projeto. Foram excluídas 8 amostras que haviam sido preparadas com DTT. Descartado o uso do DTT, testamos diluir as amostras na proporção 1:1 com PBS 1X. A 
diluição com PBS permitiu separar bem o sobrenadante dos debris e não comprometeu a quantificação dos microRNAs em nossos testes e devido aos bons resultados atingidos prosseguimos com a diluição com PBS 1X para todas as amostras.

\section{3 -Revisão Da literatura e escolha dos microRNAs}

A revisão da literatura com os termos citados anteriormente na metodologia resultou em 1073 artigos, desses foram removidas as 105 revisões e os 94 artigos repetidos entre as listas resultando em 874 artigos para serem avaliados.

Fizemos uma análise inicial, quando 723 artigos haviam sido analisados e 48 selecionados e detalhados em planilha, considerando apenas as moléculas oriundas dos trabalhos de câncer de cabeça e pescoço, esôfago e pulmão fizemos uma análise utilizando o software IPA (Ingenuity Pathway Analysis). Nesta análise nos chamou a atenção o miR-296-5p que apareceu como um regulador upstream de 6 genes, AKT1, TP53, BCL2, CCND1, COL1A1, PCNA, com os quais tem uma regulação indireta (Figura 10). Esses genes estão envolvidos em processos importantes com apoptose, proliferação celular, diferenciação, progressão do ciclo celular, migração, transformação e são encontrados desregulados em vários tipos de tumor. O miR-296 não foi descrito em nenhum dos trabalhos que foram detalhados e foi escolhido por ter sido o único microRNA que apareceu como regulador nessa análise inicial. 


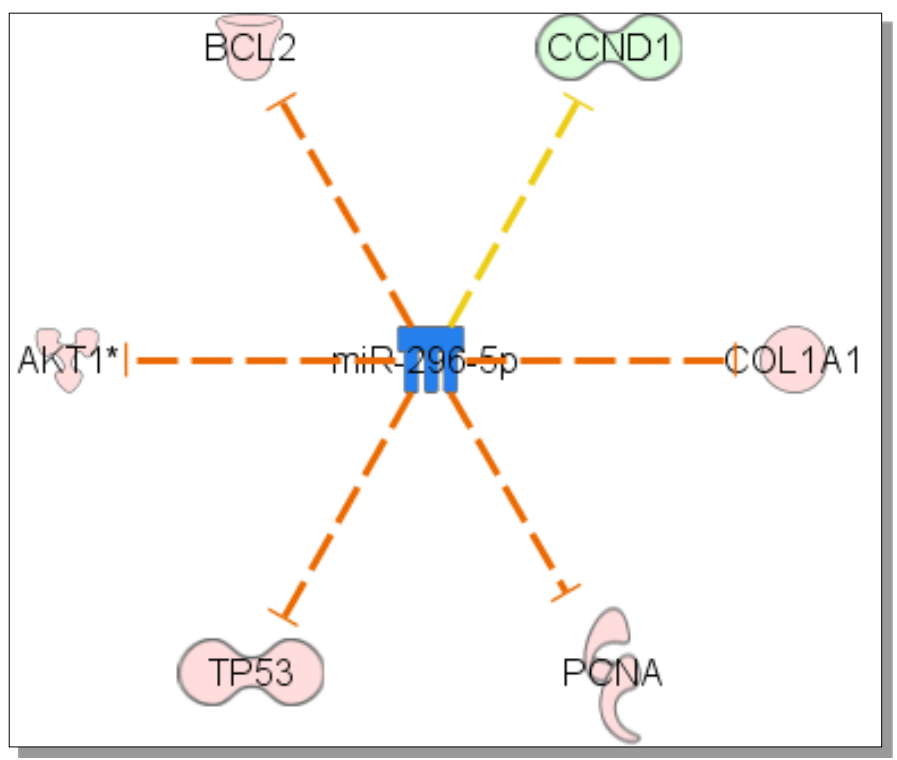

\section{LEGENDA}

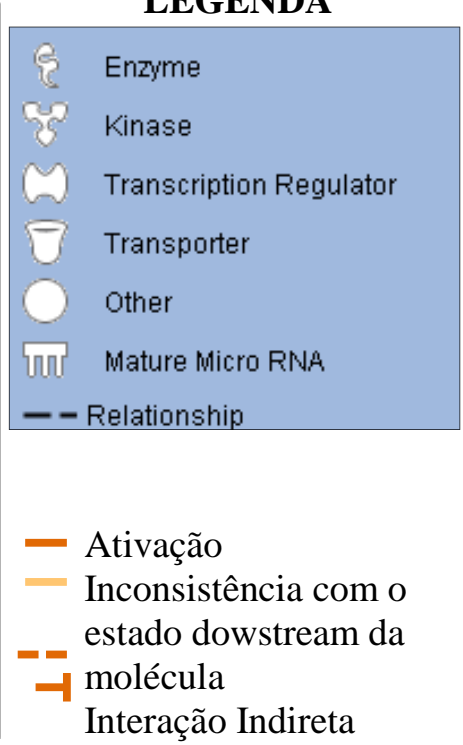

Figura 10 - Esquema gerado pelo IPA onde o miR-296-5p apresenta relação indireta com AKT1, TP53, BCL2, CCND1, COL1A1, PCNA.

Nessa análise inicial, também escolhemos outro três microRNAs, miR-21-5p, miR-200b-3p, miR-15a-5p, porque observamos que eles eram descritos em diversos trabalhos sendo associados ao tratamento com cisplatina e/ou radioterapia, além de terem aparecido em algumas vias moleculares resultante da análise com o IPA. Alguns desses trabalhos estão descritos na Tabela 3. 
Tabela 3- Alguns artigos incluídos que relacionam a expressão dos microRNAs, miR-200, miR-21 e miR-15 a quimio ou radiorresistência.

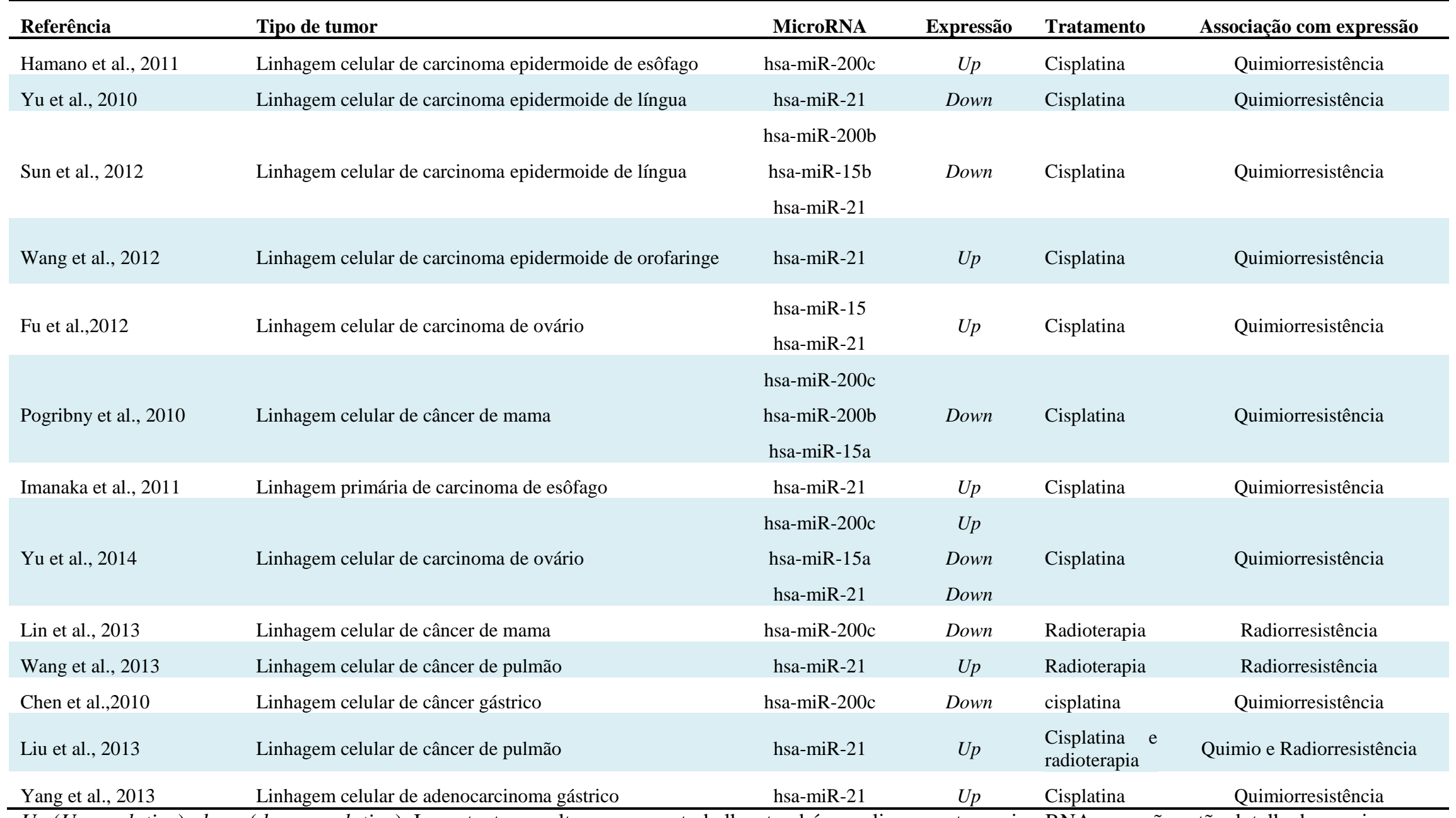

Up (Upregulation), down (downregulation). Importante ressaltar que esses trabalhos também avaliaram outros microRNAs que não estão detalhados aqui. 
Após o término da análise dos 874 artigos, 85 foram selecionados seguindo os critérios de inclusão descritos na metodologia e tiveram os dados de expressão gênica detalhados em planilha. Como resultado da análise desses artigos obtivemos uma lista com 257 microRNAs e 76 mRNAs.

Em posse dessa lista fizemos uma busca in sílico dos alvos desses microRNAs e também dos microRNAs que regulavam os mRNAs resultante de nossa revisão. Após remover as duplicidades entre as listas obtivemos 3103 moléculas. Fizemos uma análise com o software IPA e em detrimento do número muito grande de moléculas obtivemos vias gênicas muito genéricas e por isso optamos por usar na análise no IPA apenas as moléculas obtidas diretamente da nossa revisão sistemática, sem as buscas in silico.

A análise no IPA gerou dezenas de vias moleculares. Em posse dessas vias, estudamos cada uma delas para identificar os microRNAs envolvidos nos mecanismos de resposta ao tratamento QRT e assim selecionar outros 4 microRNAs para serem avaliados neste trabalho. Além disso, pudemos confirmar alguns mecanimos moleculares que os microRNAs selecionados anteriormente estão envolvidos na resposta ao tratamento QRT.

O mir-200b apareceu nas vias gênicas como um inibidor do ZEB1 (Figura 11). Ele tem sido descrito com menor expressão na resistência a cisplatina em diversos tumores. Em câncer gástrico ele está associado à regulação da transição epitéliomesenquima pela inibição da expressão do ZEB2 (Kurashige et al., 2012). 


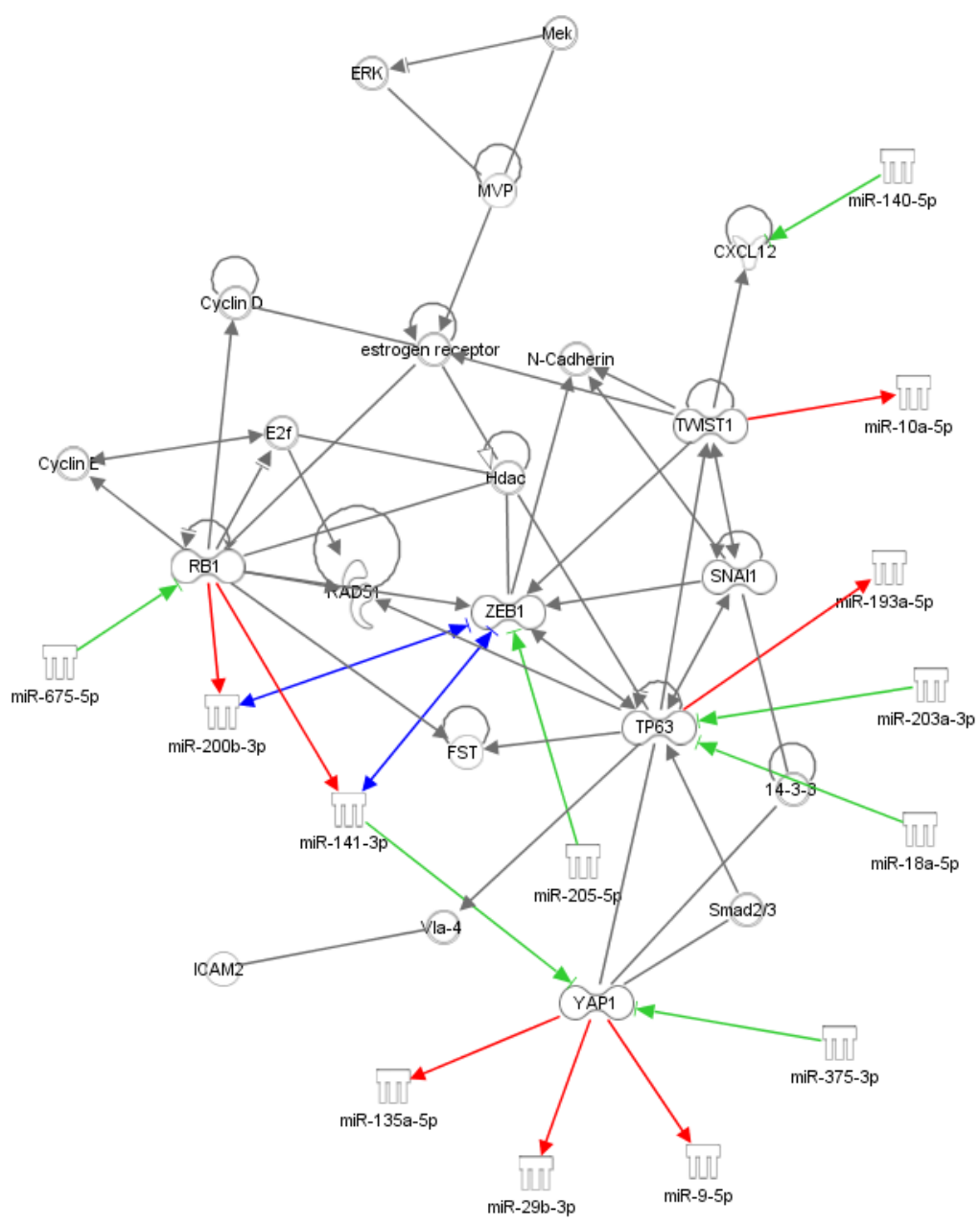

Figura 11 - Esquema gerado pelo software IPA onde o miR-200b aparece como um inibidor do ZEB1.

O miR-21 e miR-23a estão aumentados na quimiorresitência, ambos regulam a expressão do PTEN (Figura 12). O miR-21 é superexpresso em vários carcinomas, inclusive em CCP onde também tem sido correlacionado com pior sobrevida, a análise da sua expressão tem sido sugerida como marcador diagnostico para CCP (Avissar et al., 2009; Selcuklu et al., 2009). A expressão aumentada em câncer de língua foi associada com baixos níveis de TPM1 e PTEN atuando como um fator antiapoptótico (Li et al., 2009). 


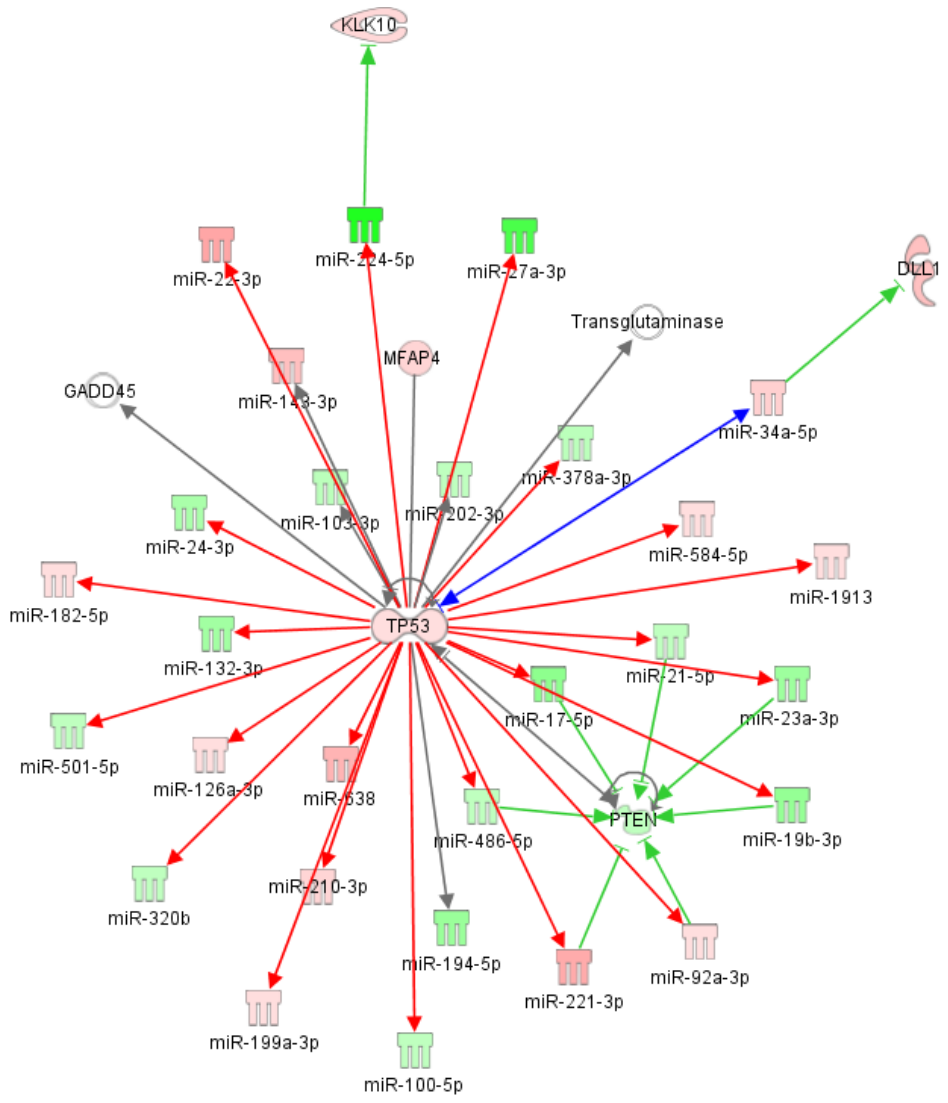

Figura 12 - Esquema gerado pelo software IPA, miR-21 e miR23a regulam PTEN.

O mir-125b inibe o lin28 que por sua vez inibe o let-7a-5p que inibe Ras regulando assim a apoptose (Figura 13). Membros da família let-7 estão reduzidos em HNSCC (Childs et al., 2009), eles regulam a atividade do RAS e diversos outro genes relacionados ao ciclo celular (Johnson et al., 2005; Johnson et al., 2007). O miR-125b esta superexpresso em plasma de pacientes com carcinoma de cavidade oral comparado a controles. Em linhagens celulares de carcinoma de cavidade oral ele foi associado com redução da taxa de proliferação, aumento da radiossensibildade e correlacionado com estadiamento tumoral e sobrevida (Shiiba et al., 2013). 


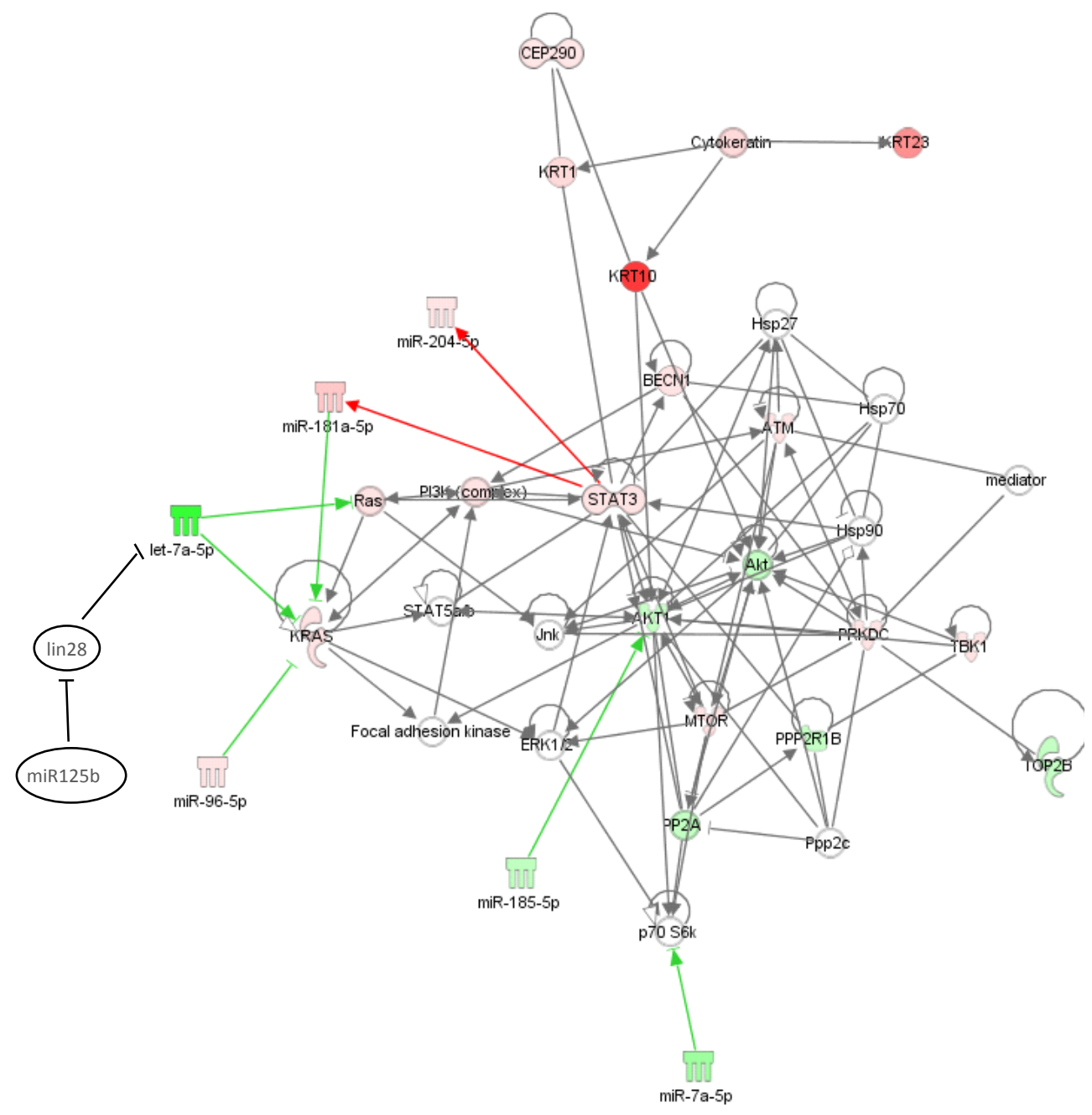

Figura 13 - Adaptação do esquema gerado pelo software IPA- miR-125b inibe lin-28 que inibe let-7a.

O mir-142-3p inibe GFI1, um repressor transcricional importante para o desenvolvimento do sistema imune (Figura 14). A perda de GFI1 leva a aumento da secreção de IL-2 que se liga ao receptor IL-2R e aumenta a expansão de Treg e CD103 e CD73, levando ao crescimento tumoral. O miR-142-3p foi primeiramente identificado no desenvolvimento do sistema linfoide (Neilson et al., 2007), foi subsequentemente considerado um oncomir em leucemias (Lv et al., 2011). Assim como outros membros da mesma família é encontrado superexpresso no carcinoma oral (Cervigne et al., 2009; Manikandan et al., 2016). 


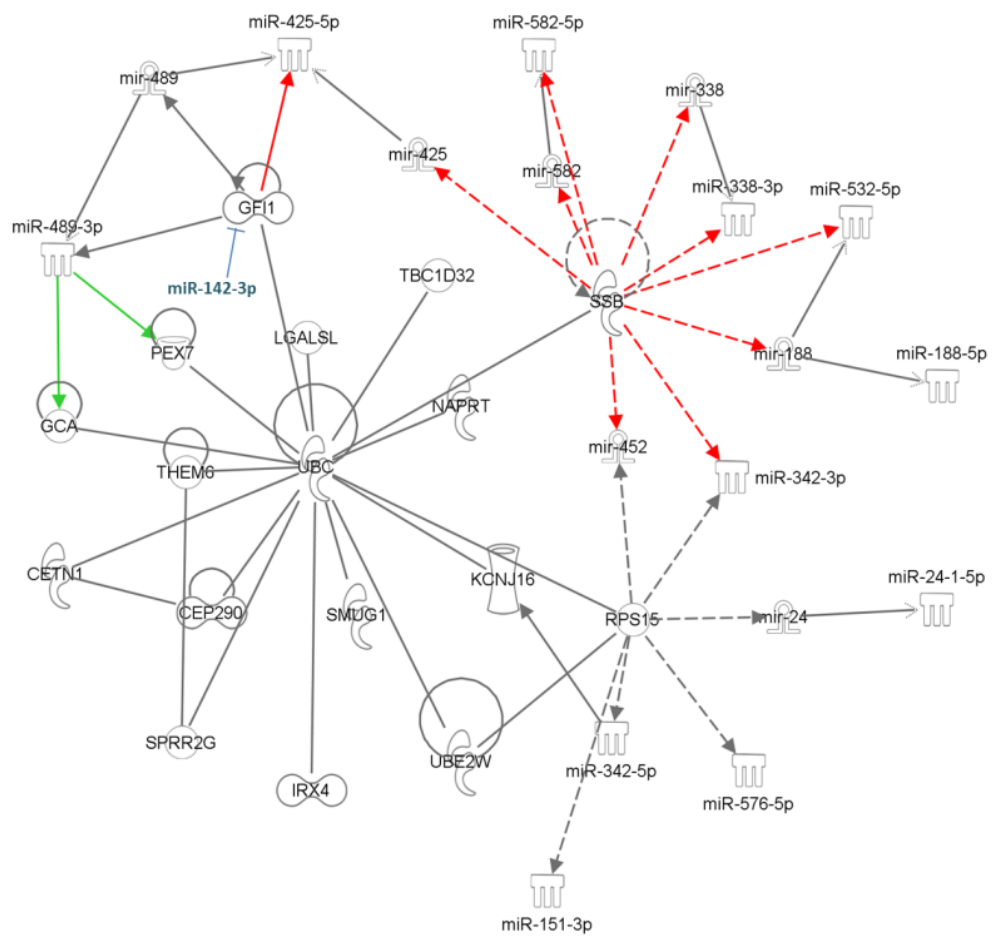

Figura 14 - Esquema adaptado do IPA - miR-142-3p regula GFI1

A expressão do miR-503-5p modula a expressão de WEE1 (Figura 15), uma proteína quinase inibidora de mitose, inibe a EMT em osteossarcoma (Guo et al., 2010) e regula a resistência do tumor de pulmão de pequenas células à cisplatina (Qiu et al., 2013). 


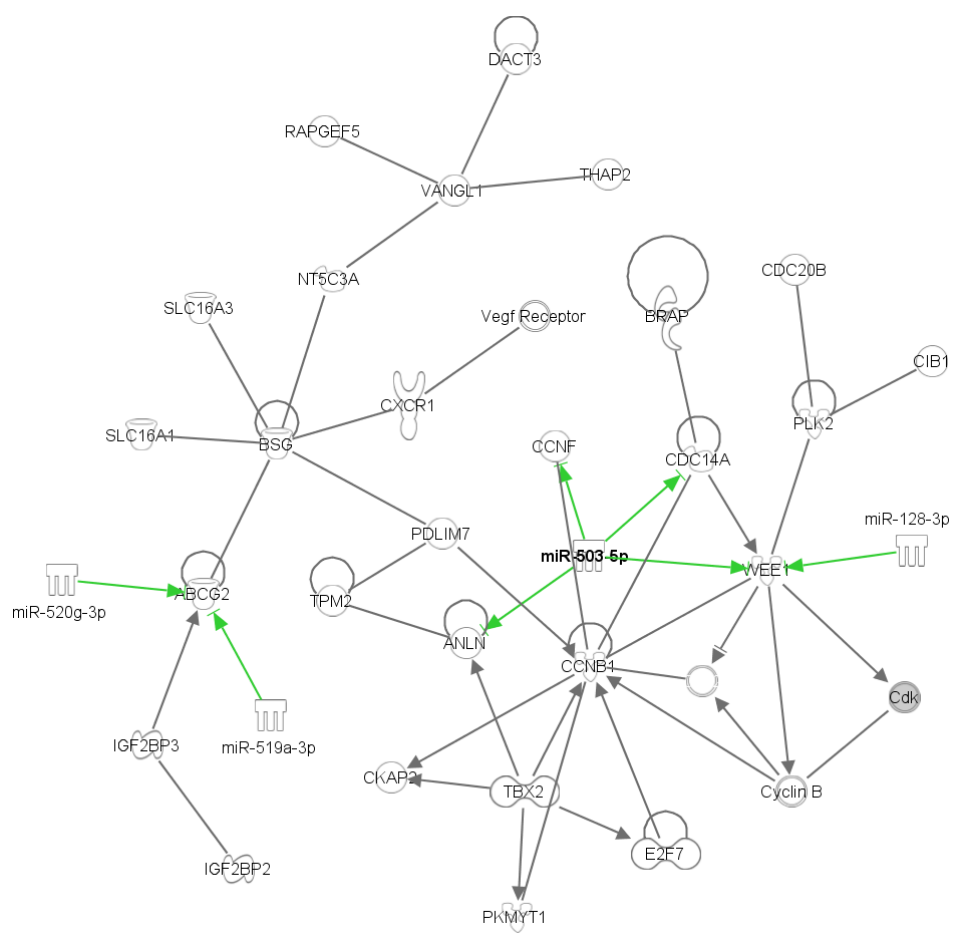

Figura 15 - Esquema adaptado do IPA - miR-503-5p e a regulação de WEE1.

\section{4 - Expressão dos microRNAs}

Neste trabalho analisamos a expressão relativa de 8 microRNAs, miR-15a-5p, miR-21-5p, miR-23a-3p, miR-125b-5p, miR-142-3p, miR-200b-3p, miR-296-5p e miR503-5p além dos normalizadores miR-16-5p e U6 snRNA e o Spike-in 6 (Sp6) usado como controle do processamento de amostras. Determinamos a expressão gênica na saliva livre de células de 62 pacientes com carcinoma de cavidade oral e orofaringe ( 31 do grupo 1, 8 do grupo 2 e 23 do grupo 3) além de 28 amostras de voluntários sadios.

Após realizarmos as extrações de RNA total das amostras de saliva livre de células dos pacientes e fazer as reações de síntese de cDNA, demos inicio aos ensaios de expressão gênica. Nós temos dois controles muito importantes nos ensaios de expressão, o UniSp6 e os normalizadores, miR-16-5p e U6snRNA. Antes de fazermos os ensaios dos microRNAs de interesse esses dois controles foram analisados.

O UniSp6 é RNA spike-in template, que é adicionado no início da extração do RNA total, e posteriormente quantificado na qRT-PCR. Ele serve como um controle positivo da reação. Como adicionamos a mesma quantidade de SP6 para todas as amostras, esperamos após a qRT-PCR encontrar valores de Cts (Cycles threshould) próximos para todas as amostras. Estabelecemos uma faixa de valores de Ct aceitável 
para o Sp6, entre o 25 e 27, e as amostras que apresentaram a média de Ct fora dessa faixa foram excluídas e nova extração de RNA e síntese de cDNA foi realizada. Quatro amostras avaliadas foram excluídas das nossas análises de expressão gênica por apresentarem valores de Cts muito altos para o UniSp6 e para os demais microRNAs mesmo após uma nova extração de RNA e síntese de cDNA, indicando que possivelmente havia algum inibidor nessas amostras. Além disso, uma quinta amostra foi excluída, pois foi identificado que o paciente apresentava um segundo tumor primário em esôfago, provavelmente ele já possuía esse tumor no momento da coleta da amostra o que seria um fator de confusão. Sendo assim foram consideradas nas análises de expressão gênica 30 amostras no grupo G1, 8 no grupo G2, 21 no grupo G3 e 26 amostras no grupo G0.

O miR-16-5p e o U6snRNA foram quantificados para serem usados na normalização dos valores de expressão. Para ser considerado um bom normalizador, a sua expressão não deve variar muito entre as amostras quando comparada entre os grupos de estudo e deve ser expresso em todas as amostras. $\mathrm{O}$ miR-16 não apresentou diferença de expressão significativa entre os grupos ( $p=0,146$ - Kruskall-Wallis), enquanto o U6 apresentou diferença entre os grupos ( $\mathrm{p}=0,00$ - Kruskall-Wallis), por esse motivo nossos dados foram normalizados pelo miR-16.

A expressão do miR-296-5p $(n=33)$ e miR-503-5p foi abaixo dos níveis de detecção em quase todas as amostras de saliva testadas. Fizemos a tentativa de usar o cDNA diluído apenas quatro vezes para quantificar o miR-503-5p, enquanto que para os outros micros diluímos 40 vezes, mas ele continuou indetectável nas amostras testadas e por isso eles foram excluídos de futuras análises.

Os dados de expressão relativa dos microRNAs estão descritos na Tabela 4 e representados nas Figura 16 e 17.

$\mathrm{Na}$ comparação da expressão dos microRNAs entre os grupos estudados (pacientes e voluntários) observamos que apenas o miR15a-5p não apresentou diferença significativa entre os 4 grupos $(\mathrm{p}=0,173$ - teste de Kruskal-Wallis). Os demais microRNAs foram diferencialmente expressos entre os grupos, miR-21-5p $(p=0.005)$, $\operatorname{miR}-23 a-3 p(p=0,026), \operatorname{miR}-125-5 p(p=0,013), \operatorname{miR}-142-3 p \quad(p=0,033)$ e miR-200b-3p ( $\mathrm{p}=0,031$ - teste de Kruskal-Wallis) (Tabela 4). 
Tabela 4 - Análise descritiva da expressão dos microRNAs analisados nas amostras de saliva de pacientes com OSCC inoperáveis e de volunatários sádios.

\begin{tabular}{|c|c|c|c|c|c|}
\hline & Controle & Grupo 1 & Grupo 2 & Grupo 3 & $\mathbf{p}$ \\
\hline $\begin{array}{c}\text { miR-15a-5p } \\
\text { Média (DP) } \\
\text { Mediana } \\
\text { (Min - Máx) }\end{array}$ & $\begin{array}{c}3,38(5,37) \\
2,06 \\
(0,0-26,87)\end{array}$ & $\begin{array}{c}3,51(4,19) \\
1,47 \\
(0,0-16,6)\end{array}$ & $\begin{array}{c}7,03(5,51) \\
6,02 \\
(0,47-14,95)\end{array}$ & $\begin{array}{c}3,54(5,08) \\
1,45 \\
(0,03-17,33)\end{array}$ & 0,173 \\
\hline $\begin{array}{c}\text { miR-21-5p } \\
\text { Média (DP) } \\
\text { Mediana } \\
\text { (Min - Máx) }\end{array}$ & $\begin{array}{c}0,79(1,22) \\
0,34 \\
(0,04-5,54)\end{array}$ & $\begin{array}{c}1,41(1,24) \\
0,92 \\
(0,19-5,02)\end{array}$ & $\begin{array}{c}0,66(0,50) \\
0,52 \\
(0,0-1,67)\end{array}$ & $\begin{array}{c}2,55(4,29) \\
1,15 \\
(0,16-18,29)\end{array}$ & 0,005 \\
\hline $\begin{array}{c}\text { miR-23a-3p } \\
\text { Média (DP) } \\
\text { Mediana } \\
\text { (Min - Máx) }\end{array}$ & $\begin{array}{c}0,69(0,91) \\
0,50 \\
(0,02-4,89)\end{array}$ & $\begin{array}{c}1,28(1,02) \\
1,14 \\
(0,0-4,97)\end{array}$ & $\begin{array}{c}0,98(0,51) \\
0,92 \\
(0,48-2,15)\end{array}$ & $\begin{array}{c}0,92(1,08) \\
0,46 \\
(0,05-4,26)\end{array}$ & 0,026 \\
\hline $\begin{array}{c}\text { miR-125b-5p } \\
\text { Média (DP) } \\
\text { Mediana } \\
\text { (Min - Máx) }\end{array}$ & $\begin{array}{c}2,38(5,22) \\
0,73 \\
(0,0-24,64)\end{array}$ & $\begin{array}{c}9,74(26,38) \\
2,10 \\
(0,20-136,5)\end{array}$ & $\begin{array}{c}1,40(0,90) \\
1,43 \\
(0,21-2,85)\end{array}$ & $\begin{array}{c}5,35(8,99) \\
2,22 \\
(0,19-41,07)\end{array}$ & 0,013 \\
\hline $\begin{array}{c}\text { miR-142-3p } \\
\text { Média (DP) } \\
\text { Mediana } \\
\text { (Min - Máx) }\end{array}$ & $\begin{array}{c}4,68(6,53) \\
1,70 \\
(0,0-26,68)\end{array}$ & $\begin{array}{c}10,68(13,27) \\
8,91 \\
(0,0-64,04)\end{array}$ & $\begin{array}{c}9,86(10,51) \\
6,37 \\
(1,0-32,09)\end{array}$ & $\begin{array}{c}28,35(74,67) \\
4,23 \\
(0,05-320,2)\end{array}$ & $\mathbf{0 , 0 3 3}$ \\
\hline $\begin{array}{c}\text { miR-200b-3p } \\
\text { Média (DP) } \\
\text { Mediana } \\
\text { (Min - Máx) }\end{array}$ & $\begin{array}{c}3,98(10,07) \\
0,95 \\
(0,0-48,89)\end{array}$ & $\begin{array}{c}4,58(7,74) \\
1,80 \\
(0,06-34,30)\end{array}$ & $\begin{array}{c}1,89(3,14) \\
0,79 \\
(0,11-9,51)\end{array}$ & $\begin{array}{c}5,85(5,20) \\
4,03 \\
(0,21-15,61)\end{array}$ & $\mathbf{0 , 0 3 1}$ \\
\hline
\end{tabular}



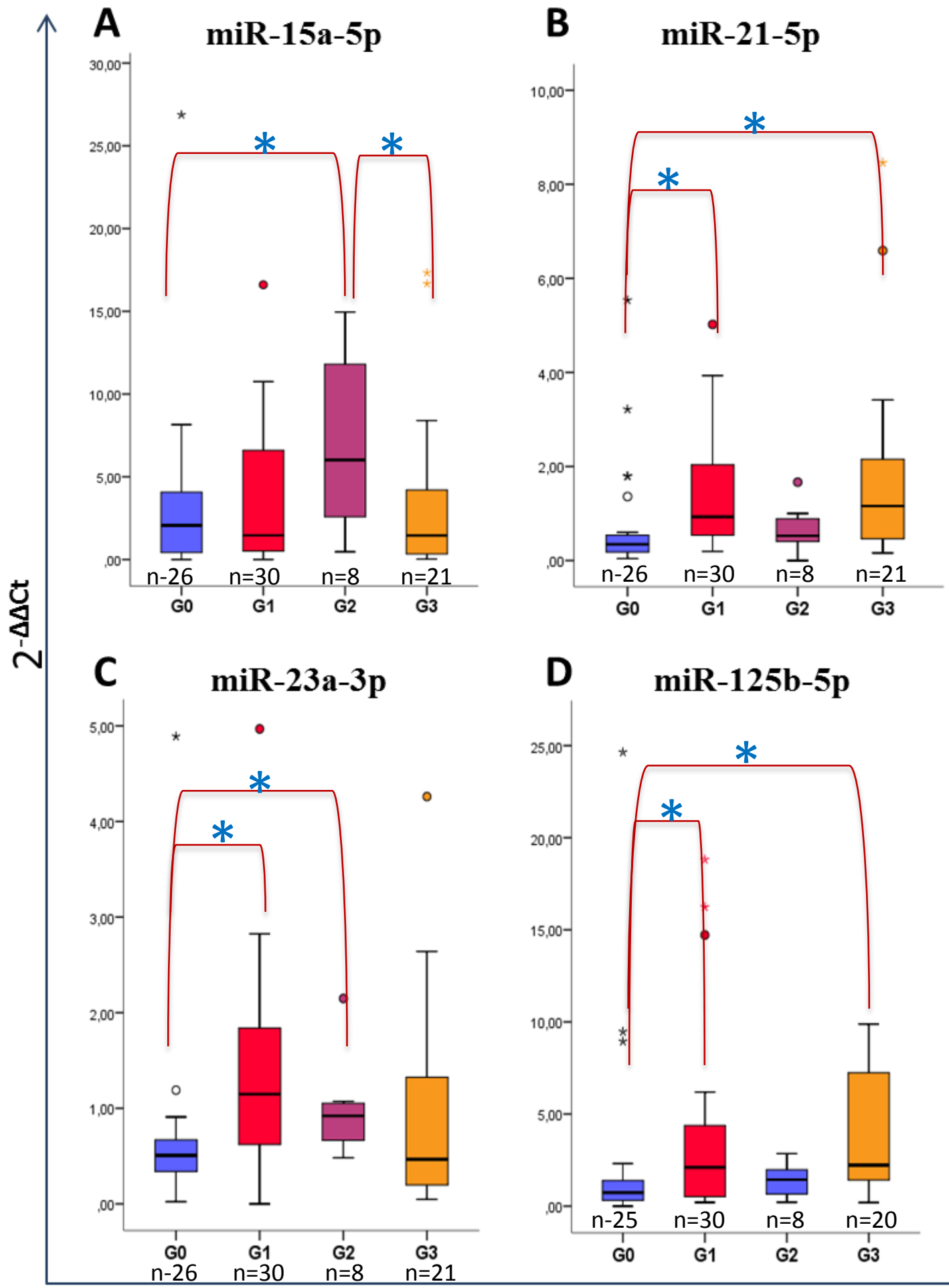

\section{GRUPOS}

Figura 16 - Representação da expressão do miR-15a-5p (A), miR-21-5p (B), miR-23a-3p (C) e miR-125b-5p (D) em cada um dos grupos estudados. G0 - Voluntários sadios, G1 Pacientes antes de iniciarem o tratamento, G2 - Pacientes com recidiva pós QRT e G3 - paciente sem evidência de doença pós QRT. * Diferença estatisticamente significativa entre os grupos. 


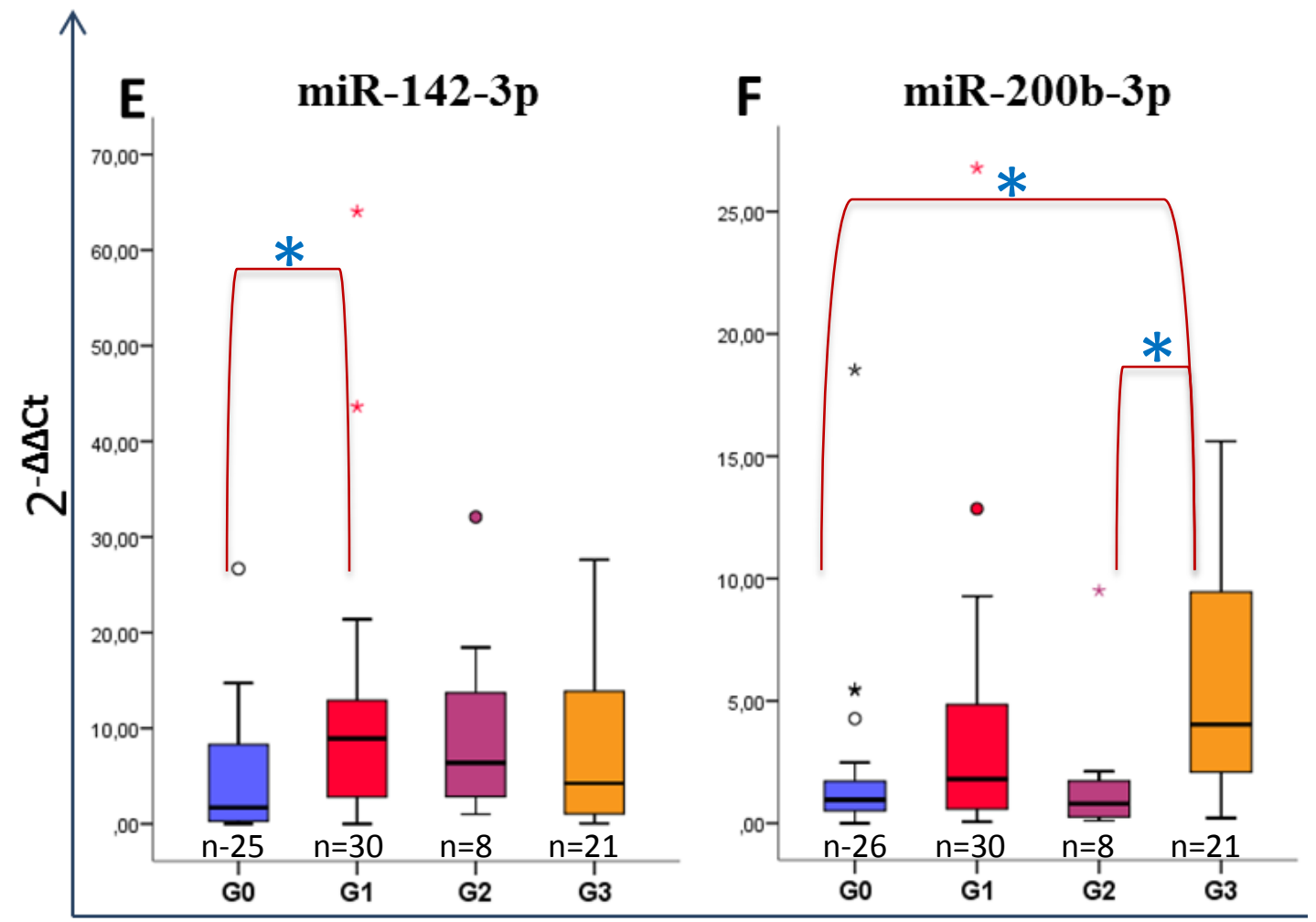

GRUPOS

Figura 17 - Representação da expressão do miR-142-3p (E) e miR-200b-3p (F) em cada um dos grupos estudados. G0 - Voluntários sadios, G1 - Pacientes antes de iniciarem o tratamento, G2 - Pacientes com recidiva pós QRT e G3 - paciente sem evidência de doença pós QRT. * Diferença estatisticamente significativa entre os grupos.

Posteriormente, analisamos as diferenças de expressão comparando os grupos dois a dois. O grupo de pacientes sem tratamento prévio (G1) quando comparado ao grupo de voluntários sadios (G0) apresentou maior expressão para os microRNAs miR$21-5 \mathrm{p} \quad(\mathrm{p}=0,001), \quad \operatorname{miR}-23 \mathrm{a}-3 \mathrm{p} \quad(\mathrm{p}=0,004), \quad \operatorname{miR}-125 \mathrm{~b}-5 \mathrm{p} \quad(\mathrm{p}=0,026)$ e miR-142-3p ( $\mathrm{p}=0,005$ - teste de Mann-Whitney).

Além disso, o grupo G3 apresentou maior expressão do mir-21-5p ( $\mathrm{p}=0,018)$, o miR-125b-5p ( $\mathrm{p}=0,002)$ e o miR-200b-3p ( $\mathrm{p}=0,014)$ quando comparado ao grupo G0. O grupo de pacientes com recidiva da doença $(\mathrm{G} 2)$ apresentou maior expressão do mir15a-5p e miR-23a-3p quando comparado aos voluntários sadios (G0) (p=0,023 e 0,017; respectivamente). Por fim, quando comparamos os valores de expressão entre os grupos G2 e G3, tivemos maior expressão do miR-200b-3p $(p=0,019)$ e menor do miR-15a-5p 
( $\mathrm{p}=0,057$ - teste de Mann-Whitney) no grupo 3. Não encontramos diferença significativa nas demais comparações (Tabela 5).

Tabela 5 - Comparação da expressão relativa dos microRNAs nos diferentes grupos de amostras.

\begin{tabular}{lcccccc}
\hline & G0xG1 & G0xG2 & G0xG3 & G1xG2 & G1xG3 & G2xG3 \\
\hline miR-15a-5p & 0,588 & $\mathbf{0 , 0 2 3}$ & 0,864 & 0,079 & 0,848 & $\mathbf{0 , 0 5 7}$ \\
miR-21-5p & $\mathbf{0 , 0 0 1}$ & 0,291 & $\mathbf{0 , 0 1 8}$ & 0,100 & 0,833 & 0,242 \\
miR-23a-3p & $\mathbf{0 , 0 0 4}$ & $\mathbf{0 , 0 1 7}$ & 0,864 & 0,591 & 0,141 & 0,223 \\
miR-125b-5p & $\mathbf{0 , 0 2 6}$ & 0,257 & $\mathbf{0 , 0 0 2}$ & 0,210 & 0,593 & 0,075 \\
miR-142-3p & $\mathbf{0 , 0 0 5}$ & 0,064 & 0,076 & 0,886 & 0,444 & 0,526 \\
miR-200b-3p & 0,189 & 0,490 & $\mathbf{0 , 0 1 4}$ & 0,197 & 0,112 & $\mathbf{0 , 0 1 9}$ \\
\hline
\end{tabular}

G0 - Voluntários sadios, G1 - Pacientes antes de iniciarem o tratamento, G2 - Pacientes com recidiva pós QRT e G3 - paciente sem evidência de doença pós QRT. p- valor estatístico determinado pelo teste de Mann-Whitney

Os pacientes do grupo G1 tiveram amostras coletadas antes do tratamento e por meio do prontuário eletrônico acompanhamos o seguimento clínico desses pacientes, o que nos permite fazer algumas análises clínicas.

Não encontramos diferença significativa da expressão dos microRNAs em relação ao estadiamento tumoral (miR-15a-5p ( $\mathrm{p}=0,50), 21-5 \mathrm{p} \quad(\mathrm{p}=0,85), 23 \mathrm{a}-3 \mathrm{p}$ $(\mathrm{p}=0,29), 125 \mathrm{~b}-5 \mathrm{p}(\mathrm{p}=0,94), 142-3 \mathrm{p}(\mathrm{p}=0,38)$ e 200b-3p ( $\mathrm{p}=0,83)$ nem em relação ao grau histológico (15a-5p ( $\mathrm{p}=0,92), 21-5 \mathrm{p}(\mathrm{p}=0,49), 23 \mathrm{a}-3 \mathrm{p}(\mathrm{p}=0,88), 125 \mathrm{~b}-5 \mathrm{p}(\mathrm{p}=0,84)$, $142-3 p(p=0,13)$ e $200 b-3 p(p=0,66))$.

No grupo G1, o miR-21-5p teve maior expressão nos pacientes tabagistas $(\mathrm{p}=0,001)$ e etilistas $(\mathrm{p}=0,046)$ quando comparados aos pacientes ex-tabagistas e exetilistas (cessado o uso há pelo menos 1 ano antes da coleta das amostras). Além disso, o miR-200b-3p ( $\mathrm{p}=0,013)$ também apresentou maior expressão no grupo de pacientes etilistas. Não encontramos diferença em relação aos demais microRNAs e tabagismo; $\operatorname{miR}-15 a-5 p \quad(p=0,46), \quad \operatorname{miR}-23 a-3 p \quad(p=0,61), \quad \operatorname{miR}-125 b-5 p \quad(p=0,09), \quad \operatorname{miR}-142-3 p$ 
$(p=0,92)$ e miR-200b-3p ( $p=0,09)$ nem em relação ao etilismo; miR-15a-5p ( $p=0,35)$, miR-23a-3p ( $p=0,89)$, miR-125b-5p ( $p=0,077)$, miR-142-3p ( $\mathrm{p}=0,75$ - teste de MannWhitney) (Figura 18). Para essas análises não consideramos os pacientes que nunca fumaram ou nunca beberam, pois temos apenas 1 indivíduo nessa categoria.

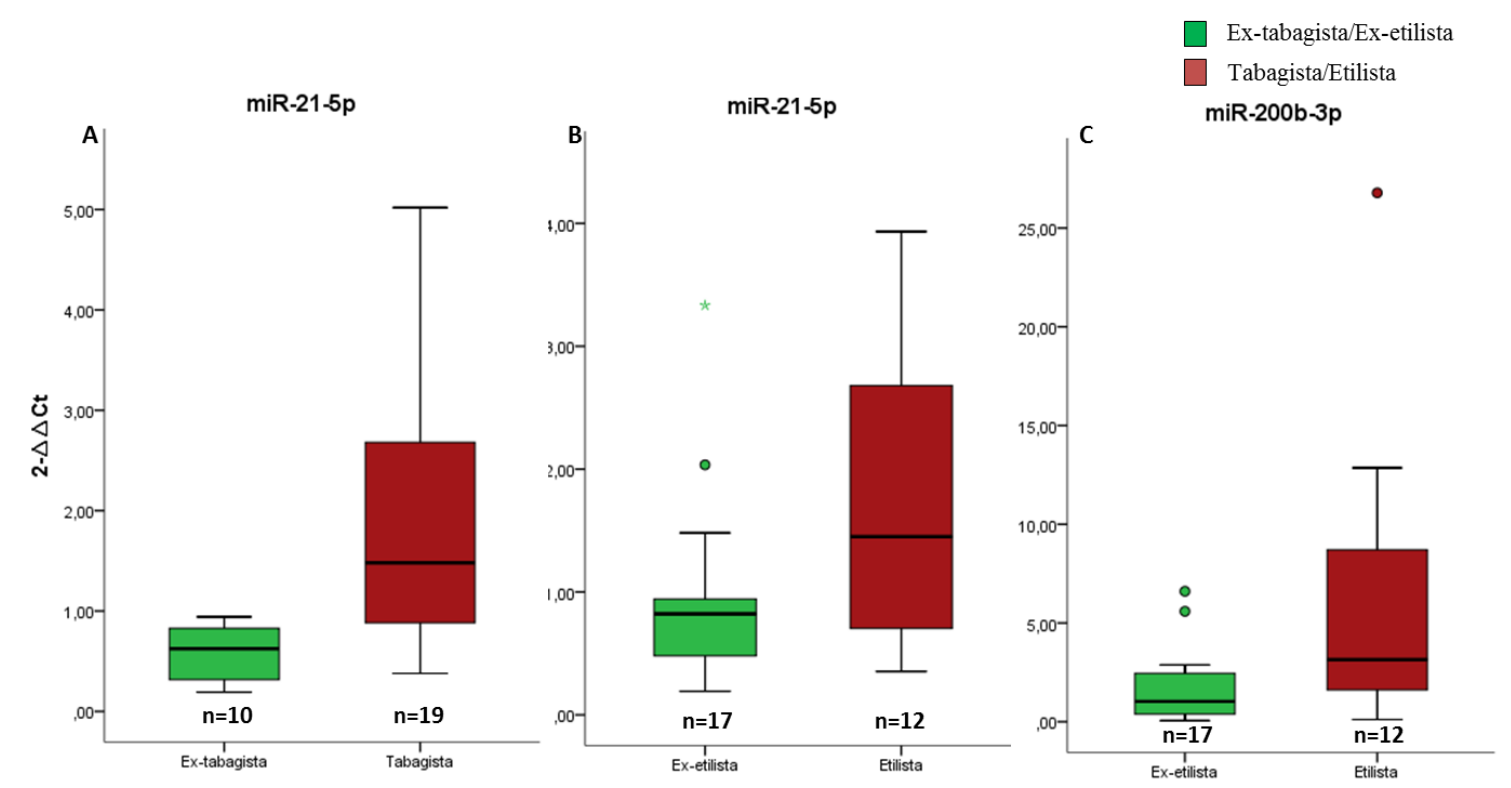

Figura 18 - Representação da expressão do miR-21-5p em relação ao tabagismo (A) e etilismo (B) e do miR-200b-3p em relação ao etilismo (C).

Avaliamos também se a expressão desses microRNAs está associada a resposta desses pacientes ao tratamento QRT e não encontramos nenhuma diferença significativa em relação à resposta inicial feita pelo médico, 8-12 semanas após o término do tratamento, bem como com a resposta a longo prazo (falha de tratamento e status global) (Tabela 6). 
Tabela 6 - Associação da expressão dos microRNAs com avaliação de resposta ao tratamento nos pacientes do grupo 1

\begin{tabular}{|c|c|c|c|c|c|c|}
\hline & \multicolumn{2}{|c|}{ Resposta Inicial* } & \multicolumn{2}{|c|}{$\begin{array}{c}\text { Falha de } \\
\text { Tratamento* }\end{array}$} & \multicolumn{2}{|c|}{ Status Global } \\
\hline & $\begin{array}{c}\text { Não } \\
\text { respondedor } \\
\text { /parcial }\end{array}$ & Completa & $\begin{array}{c}\text { Sem } \\
\text { recidiva }\end{array}$ & $\begin{array}{c}\text { Recidiva/ } \\
\text { progressão }\end{array}$ & Vivo & Morto \\
\hline miR-15a-5p & & & & & & \\
\hline Mediana (n) & \multicolumn{2}{|c|}{$\mathrm{p}=0,93$} & \multicolumn{2}{|c|}{$\mathrm{p}=0,81$} & \multicolumn{2}{|c|}{$\mathrm{p}=0,49$} \\
\hline $\begin{array}{l}\text { miR-21-5p } \\
\text { Mediana (n) }\end{array}$ & $0.83(9)$ & $0,91(15)$ & $0,93(14)$ & $0,82(10)$ & $0,93(17)$ & $0,83(13)$ \\
\hline & \multicolumn{2}{|c|}{$\mathrm{p}=0,79$} & \multicolumn{2}{|c|}{$\mathrm{p}=0,90$} & \multicolumn{2}{|c|}{$\mathrm{p}=0,63$} \\
\hline $\begin{array}{l}\text { miR-23a-3p } \\
\text { Mediana (n) }\end{array}$ & $\begin{array}{r}1,29(9) \\
p=0,\end{array}$ & $1,01(15)$ & $\begin{array}{r}0.91(14) \\
\mathrm{F}\end{array}$ & $0,68^{1,48(10)}$ & $\begin{array}{r}1,01(17) \\
\mathrm{p}=\end{array}$ & $\begin{array}{l}1,34(13) \\
78\end{array}$ \\
\hline $\begin{array}{c}\text { miR-125b-5p } \\
\text { Mediana (n) }\end{array}$ & $\begin{array}{r}1,15(9) \\
\mathrm{p}=0,\end{array}$ & $2,60(15)$ & 2,82(14) & $0,95^{1,59(10)}$ & $\begin{array}{r}2,18(17) \\
\mathrm{p}=\end{array}$ & $\begin{array}{l}2,04(13) \\
95\end{array}$ \\
\hline $\begin{array}{l}\text { miR-142-3p } \\
\text { Mediana (n) }\end{array}$ & $\begin{array}{r}3,54(9) \\
\mathrm{p}=0,\end{array}$ & $10,35(15)$ & 9,19(14) & $0,68^{6,67(10)}$ & $\begin{array}{r}6,09(17) \\
\mathrm{p}=\end{array}$ & $\begin{array}{l}10,17(13) \\
54\end{array}$ \\
\hline $\begin{array}{c}\text { miR-200b-3p } \\
\text { Mediana (n) }\end{array}$ & $\begin{array}{r}2,97(9) \\
\mathrm{p}=0,\end{array}$ & $1,82(15)$ & 2,14(14) & $0,95^{2,46(10)}$ & $\begin{array}{r}1,83(17) \\
\mathrm{p}=\end{array}$ & $\begin{array}{l}1,78(13) \\
85\end{array}$ \\
\hline
\end{tabular}

Resposta Inicial - baseada na avaliação do médico observador. $\mathrm{p}=$ valor estatístico determinado pelos testes Mann-whitney. Falha de tratamento=recidiva ou progressão da doença pós QRT. *5 pacientes faleceram ou perderam segmento durante o tratamento e 1 ainda não possui avaliação de resposta.

Com relação à sobrevida livre de progressão, os micros miR-15a-5p, miR-125b5p, e miR-142-3p apresentaram associação com sobrevida livre de progressão, porém não atingiram significância estatística. Os pacientes com menor expressão desses microRNAs apresentaram uma tendência de menor tempo para progressão da doença (sobrevida mediana de 14,65 meses) que os pacientes com expressão aumentada para esses micros (sobrevida mediana não atingida) (Figura 19 e Tabela 7). Da mesma maneira, na sobrevida global as diferenças de expressão para nenhum dos microRNAs analisados também não atingiram significância estatística, porém é possível notar que os pacientes que apresentam baixa expressão do miR-125b-5p e alta expressão do miR- 
23a-3p apresentam uma tendência de pior sobrevida (19,28 e 20,27 meses; respectivamente contra sobrevida mediana não atingida (Figura 20 e Tabela 7).
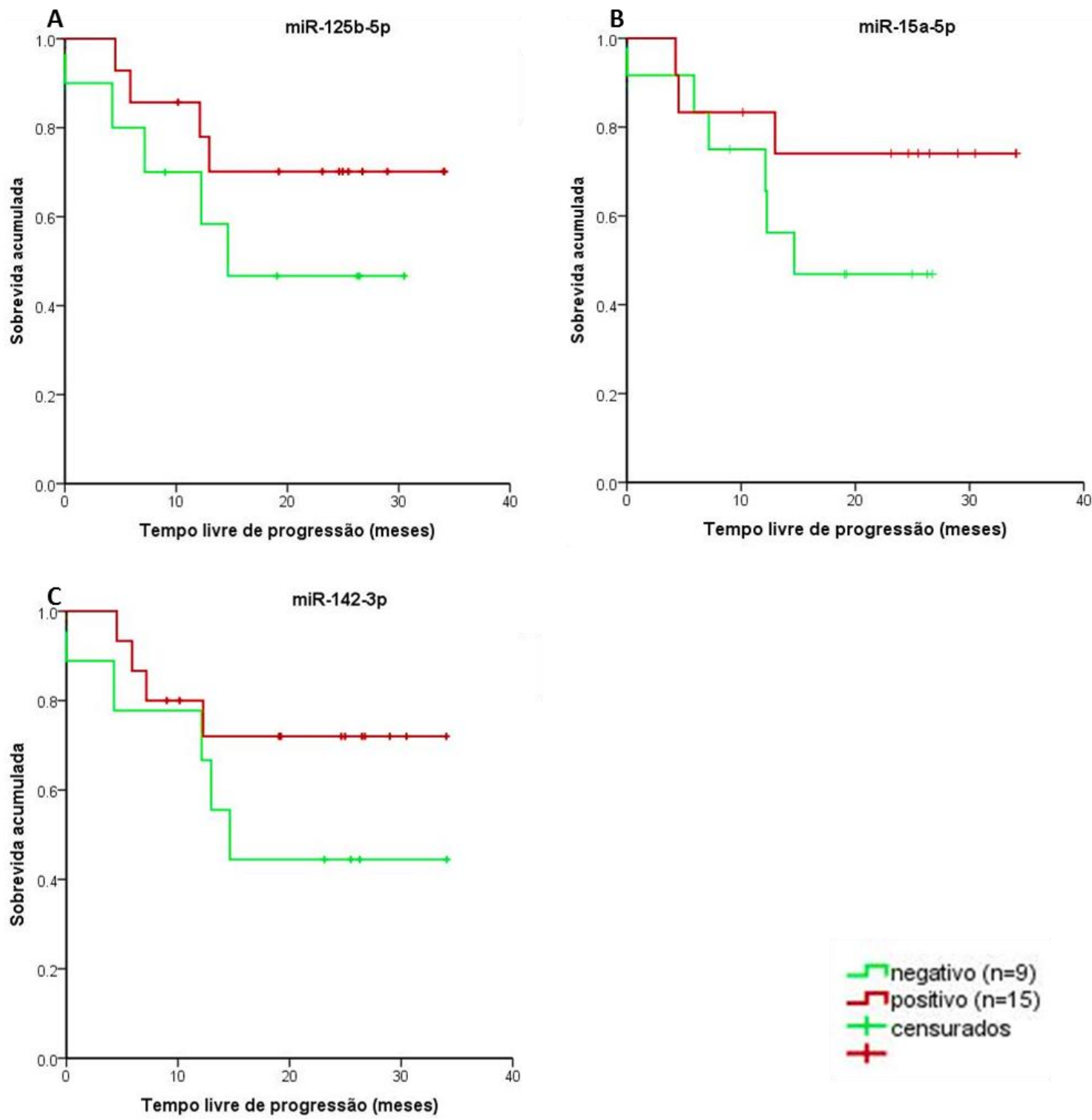

Figura 19 - Curvas de Kaplan-Meier para a sobrevida livre de progressão dos pacientes do grupo G1. 


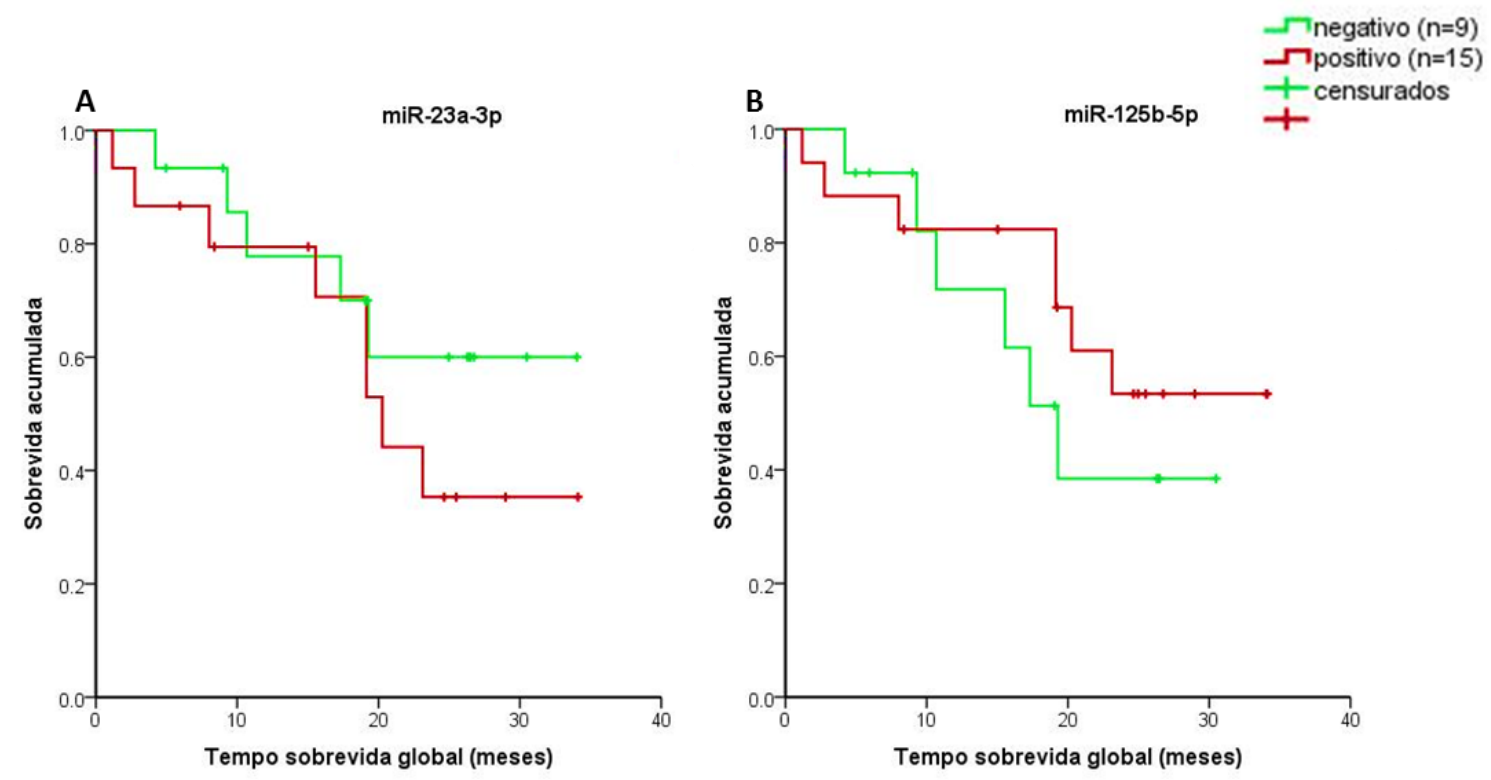

Figura 20 - Curvas de Kaplan-Meier para sobrevida global dos pacientes do grupo G1.

Tabela 7 - Análise de sobrevida para os pacientes do grupo G1.

\begin{tabular}{ccccccc}
\hline & $\mathbf{N}$ & $\begin{array}{c}\text { Sobrevida livre } \\
\text { progressão } \\
\text { (meses) }\end{array}$ & $\mathbf{p}$ & $\mathbf{N}$ & $\begin{array}{c}\text { Sobrevida } \\
\text { global (meses) }\end{array}$ & $\mathbf{p}$ \\
\hline $\begin{array}{c}\text { miR-15a-5p } \\
\text { negativo }\end{array}$ & 12 & 14,65 & 0,23 & 17 & 20,27 & 0,57 \\
positivo & 12 & NA & & 13 & 23,12 & \\
$\begin{array}{c}\text { miR-21-5p } \\
\text { negativo }\end{array}$ & 15 & 24,83 & 0,69 & 17 & 20,27 & 0,49 \\
positivo & 9 & 22,69 & & 13 & 23,12 & \\
miR-23a-3p & 13 & 25,40 & 0,51 & 15 & NA & 0,31 \\
$\begin{array}{c}\text { negativo } \\
\text { positivo }\end{array}$ & 11 & 22,20 & & 15 & 20,27 & \\
miR-125b-5p & 10 & 14,65 & 0,26 & 13 & 19,28 & 0,39 \\
$\begin{array}{c}\text { negativo } \\
\text { positivo }\end{array}$ & 14 & NA & & 17 & NA & \\
miR-142-3p & 9 & 14,65 & 0,22 & 11 & 23,12 & 0,89 \\
negativo & 15 & $\mathrm{NA}$ & & 19 & NA & \\
positivo & & & & & & \\
miR-200b-3p & 11 & 23,46 & 0,45 & 16 & 23,12 & 0,62 \\
$\begin{array}{l}\text { negativo } \\
\text { positivo }\end{array}$ & 13 & 22,23 & & 14 & NA & \\
\hline
\end{tabular}

p: significância estatística, teste de Log-rank ; N: número de pacientes; NA: mediana não atingida 


\section{5 - Visualização e quantificação de microvesículas}

Um dos nossos objetivos específicos foi verificar se os microRNAs presentes na saliva estão contidos em microvesículas. Para responder a esse tópico, nós isolamos e caracterizamos as Mvs e posteriormente quantificamos o miR-21 no pellet de Mvs e no sobrenadante livre de Mvs.

O isolamento de Mvs foi feito através de múltiplos passos de ultracentrifugação, baseado em protocolos existentes na literatura (Thery et al., 2002) e também com o uso do ExoQuick (System Biosciences).

Para demonstrarmos que o protocolo de separação de microvesículas foi eficiente, fizemos a MET (microscopia eletrônica de transmissão) do pellet de microvesículas obtido na ultracentrifugação. As fotomicrografias obtidas na MET mostraram que a saliva dos grupos G0, G1 e G3 contém microvesículas com formato arredondado e com tamanho variável até aproximadamente 100nm. As imagens da microscopia podem ser observadas na Figura 21. 


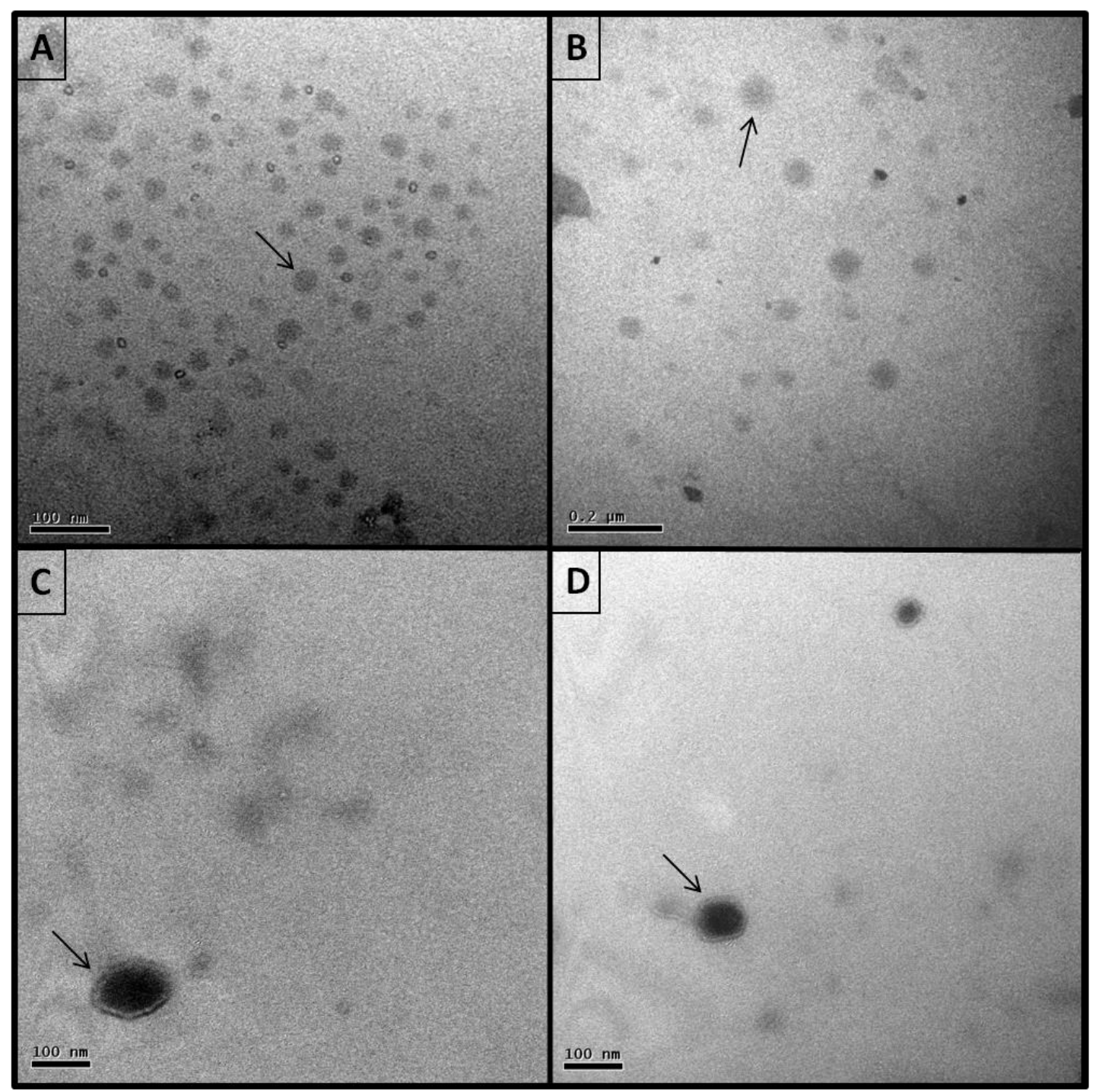

Figura 21 - Identificação de microvesículas por Microscopia Eletrônica de Transmissão Onde a foto A corresponde ao grupo controle, B ao grupo G1 e C e D ao grupo G3. A barra de escala das fotos A, C e D correspondem a 100nm e a barra da foto B correspondem a 200nm $(0,2 \mu \mathrm{m})$.

A quantificação das Mvs por tamanho foi realizada através do equipamento NANOSIGHT LM14, que quantifica a distribuição de partículas em solução por tamanho absoluto de 10-1000nm. Não encontramos diferença significativa no número de partículas entre os grupos avaliados, tanto na contagem total ( $\mathrm{p}=0,60$ - Krukallwallis) quanto na contagem de 10 a $295 \mathrm{~nm}$ ( $\mathrm{p}=0,51$ - Krukall-wallis), faixa onde temos maior concentração de partículas (Figura 23e Tabela 8). 

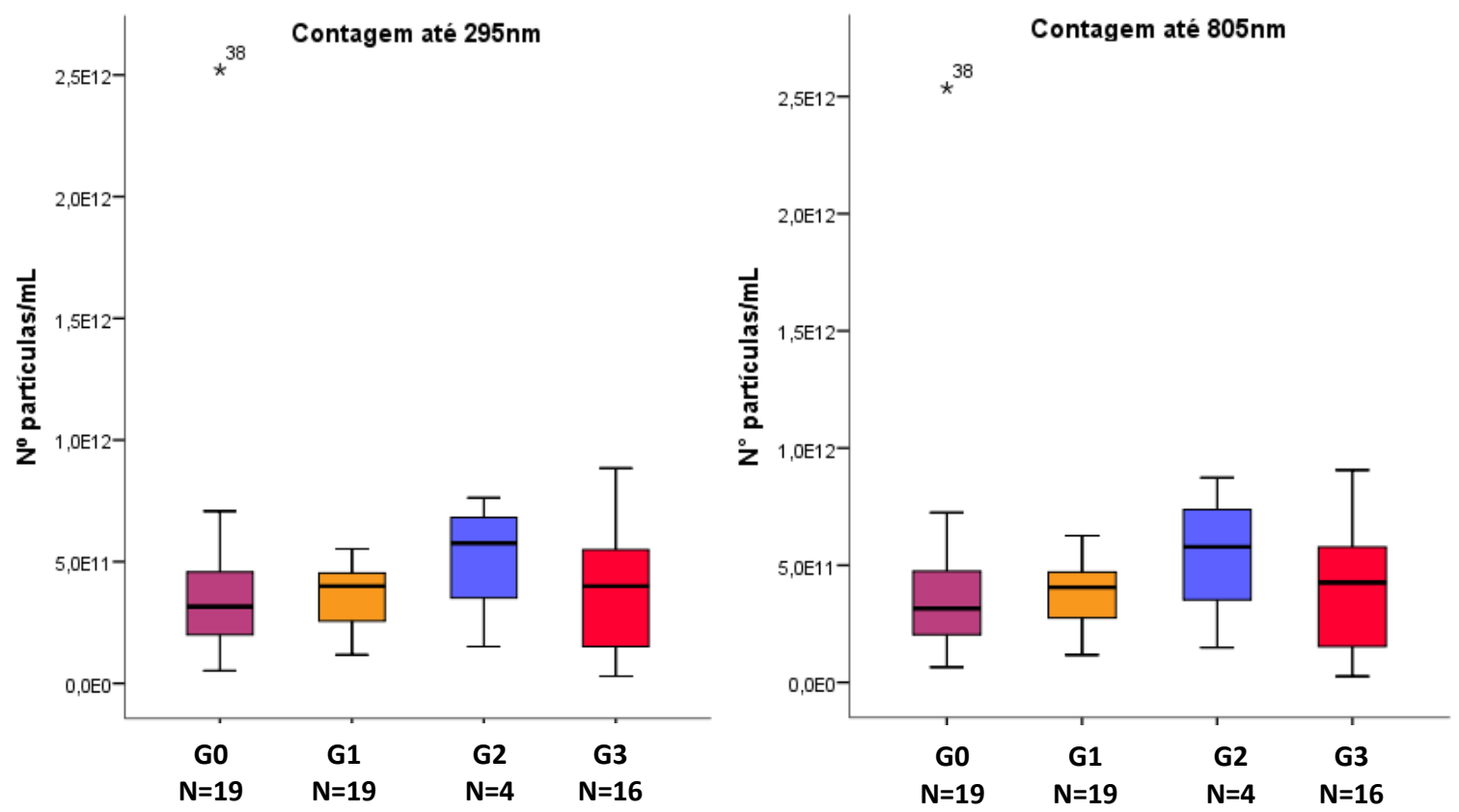

Figura 22 - Comparação entre os grupos, contagem total de partículas (0-805nm) e contagem até $295 \mathrm{~nm}$.

Tabela 8- Análise descritiva da quantificação de partículas em cada um dos grupos estudados.

\begin{tabular}{lcccc}
\hline & Crupo Controle & Grupo1 & Grupo2 & Grupo3 \\
\hline 0-895nm & & & & \\
Média & $4,55.10^{11}$ & $3,79.10^{11}$ & $5,44.10^{11}$ & $3,92.10^{11}$ \\
Mediana & $3,158.10^{11}$ & $4,05.10^{11}$ & $5,78.10^{11}$ & $4,26.10^{11}$ \\
0-295nm & & & & \\
Média & $4,45.10^{11}$ & $3,63.10^{11}$ & $5,16.10^{11}$ & $3,68.10^{11}$ \\
Mediana & $3,157.10^{11}$ & $3,99.10^{11}$ & $5,75.10^{11}$ & $3,99.10^{11}$ \\
\hline
\end{tabular}

Os histogramas abaixo representam a média da distribuição de partículas por tamanho em cada grupo. Observamos pela Tabela 8 e Figura 23 que a maioria das partículas quantificadas possuem entre 65 a $175 \mathrm{~nm}$ de tamanho. 

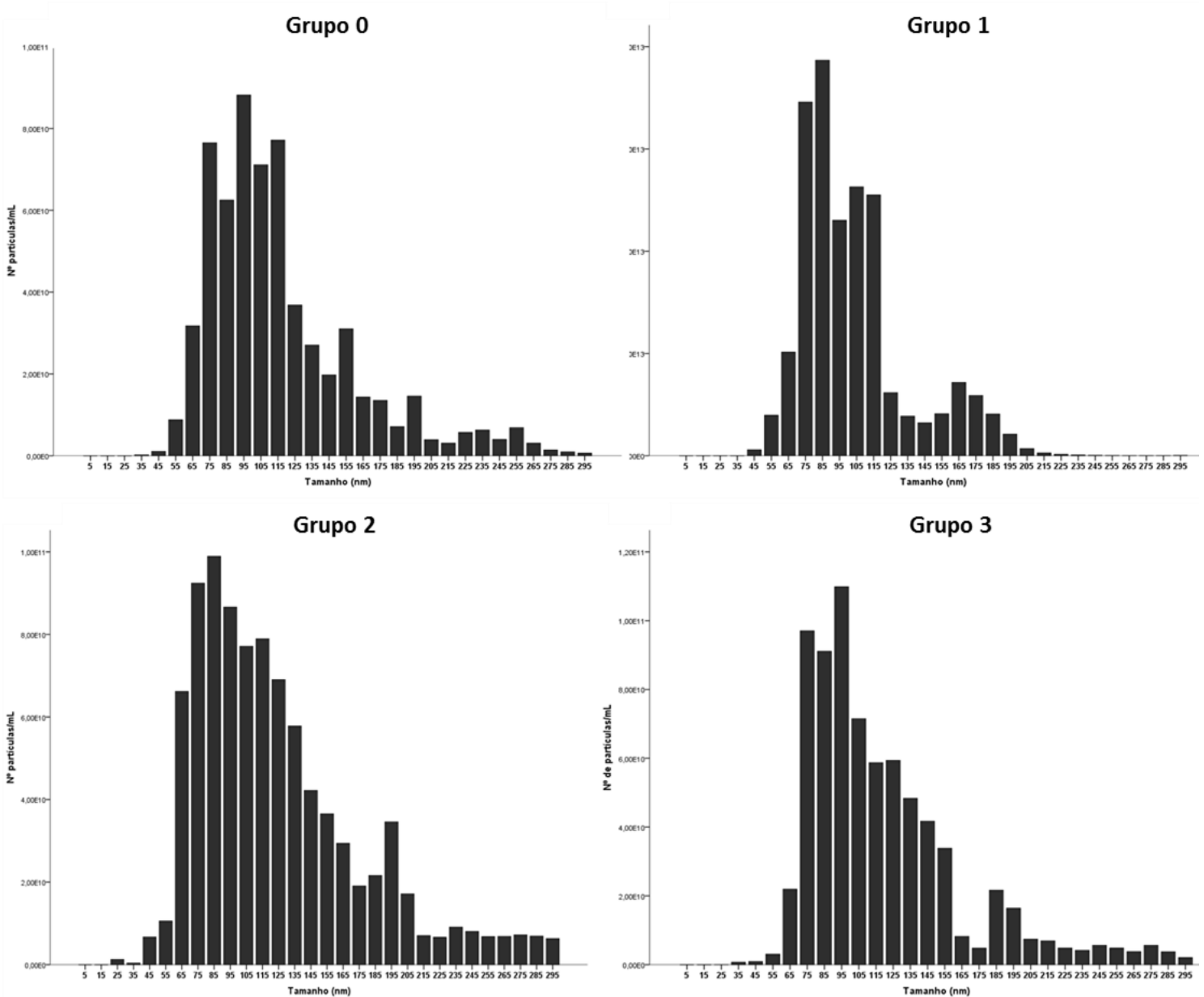

Figura 23 - Histograma com a distribuição do número de partículas por tamanho em cada grupo.

\section{6 - Determinação do antígeno CD63}

Determinamos a presença da proteína CD63 em amostras dos 4 grupos de estudo, confirmando a presença de exossomos nas nossas amostras (Figura 24 Quantificação da proteína CD63 por ELISA. Em relação ao número de partículas de exossomos presentes nas amostras, os pacientes sem tratamento prévio apresentaram menor número de partículas quando comparados ao grupo controle $(\mathrm{p}=0,01)$ assim como o grupo de pacientes com falha de tratamento também apresentaram menor número de partículas $(\mathrm{p}=0,10)$ quando comparados ao grupo de pacientes livre de doença. 


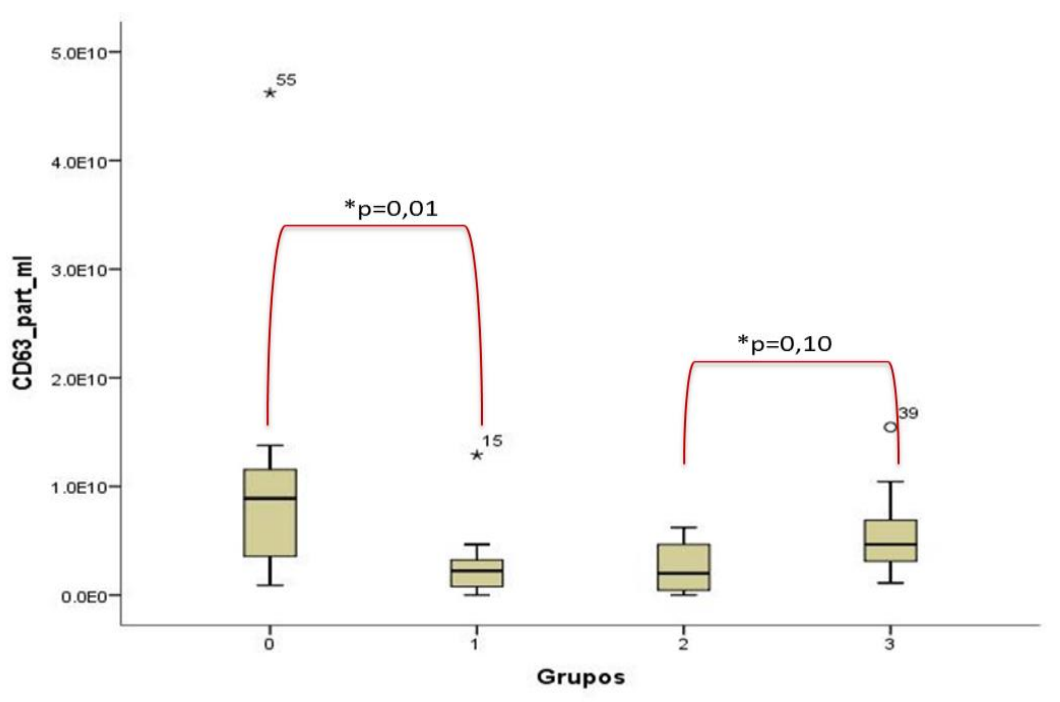

Figura 24 - Quantificação da proteína CD63 por ELISA.

\section{1 - Expressão de microRNAs contidos nas microvesículas (Mvs)}

Para verificarmos se o miR-21-5p presente na saliva dos paciente e indivíduos saudáveis está contido dentro de Mvs ou circulando livre de Mvs na saliva, nós quantificamos o miR-21-5p e miR-16-5p no pellet enriquecido de Mvs e sobrenadante livre de Mvs e comparamos com os valores obtidos na saliva total.

Inicialmente a separação de Mvs foi feita por ultracentrifugação, onde foi preciso usar um volume de aproximadamente $9 \mathrm{~mL}$ de PBS para completar o volume do tubo de ultracentrifugação. O sobrenadante resultante foi concentrado em speed vac até obtermos $1 \mathrm{~mL}$ de amostra, o que resultou em excesso de sal nessa porção da amostra inibindo as reações de PCR, inclusive do controle positivo de reação, UniSp6. Portanto, na separação de MVs por ultracentrifugação não obtivemos sucesso na determinação de microRNAs na porção de saliva livre de Mvs, sendo possível fazer a comparação da concentração do miR-21-5p apenas no concentrado de Mvs e na saliva livre de células correspondente (Figura 26). Para tentar contornar esse problema fizemos a separação de Mvs com a solução de exoQuick e realizamos a quantificação do miR-21-5p e U6snRNA no concentrado de Mvs e no sobrenadante livre de Mvs resultante da separação com Exoquick de 11 amostras e comparamos com os valores encontrados na saliva livre de células para as respectivas amostras.

O miR-21-5p foi detectado em todas as amotras de exossomo e de sobrenadante, entretanto o U6 foi detectado em 9 amostras de exossomo e em apenas 1 amostra de sobrenadante, o que inviabilizou o cálculo do $\Delta \mathrm{Ct}$ nessa análise. Na Figura 25 estão 
representados os valores de 40 - Ct do miR-21-5p onde observa-se uma concentração maior do miR-21-5p nas amostras de saliva livre de células, depois nas Mvs e em menor concentração no sobrenadante livre de Mvs. Na Figura 26 representamos os valores de 40 - Ct do miR-21-5p na saliva total e nas Mvs separados por ultracentrifugação, onde observamos que a concentração do miR-21-5p nas Mvs é próxima a concentração encontrada para a saliva livre de células.

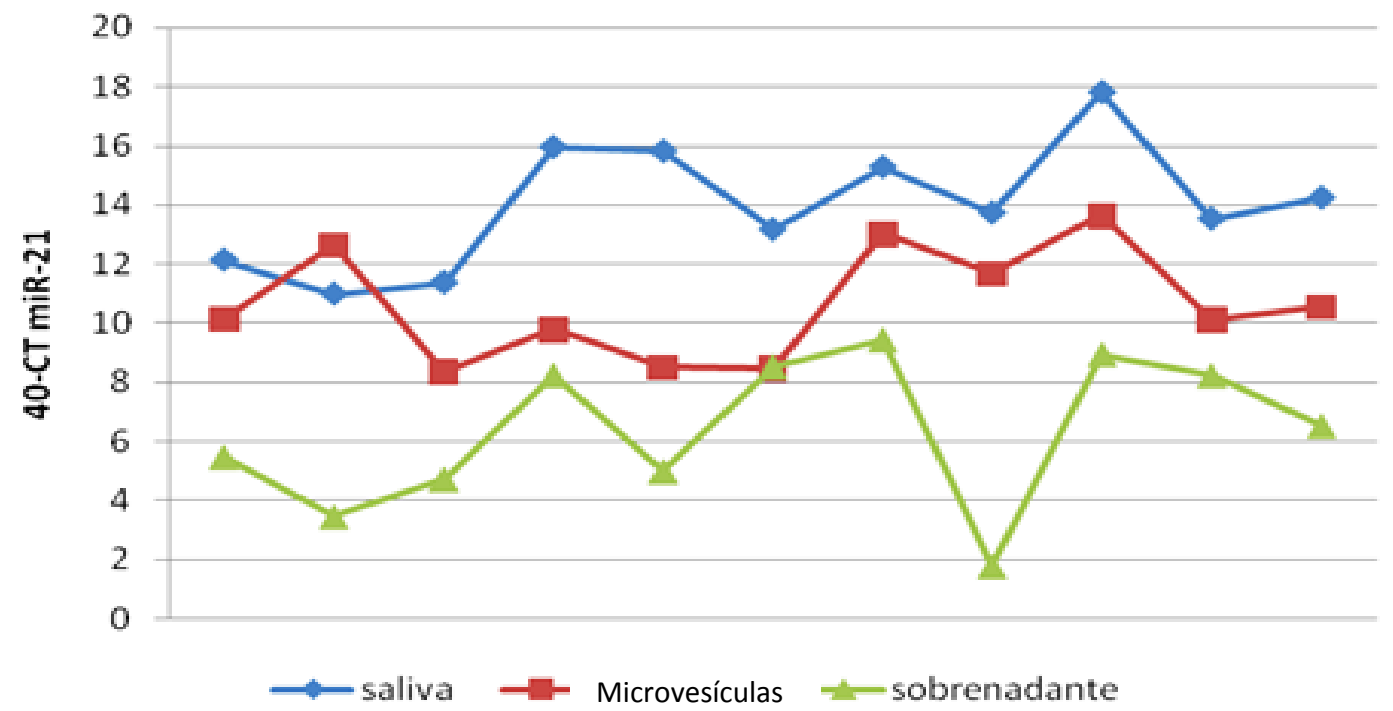

Figura 25 - Comparação dos valores Microvesículas could $(\mathrm{Ct})$ do miR-21-5p entre saliva total, Microvesículas e sobrenadante livre de Mvs separadas por exoquick.

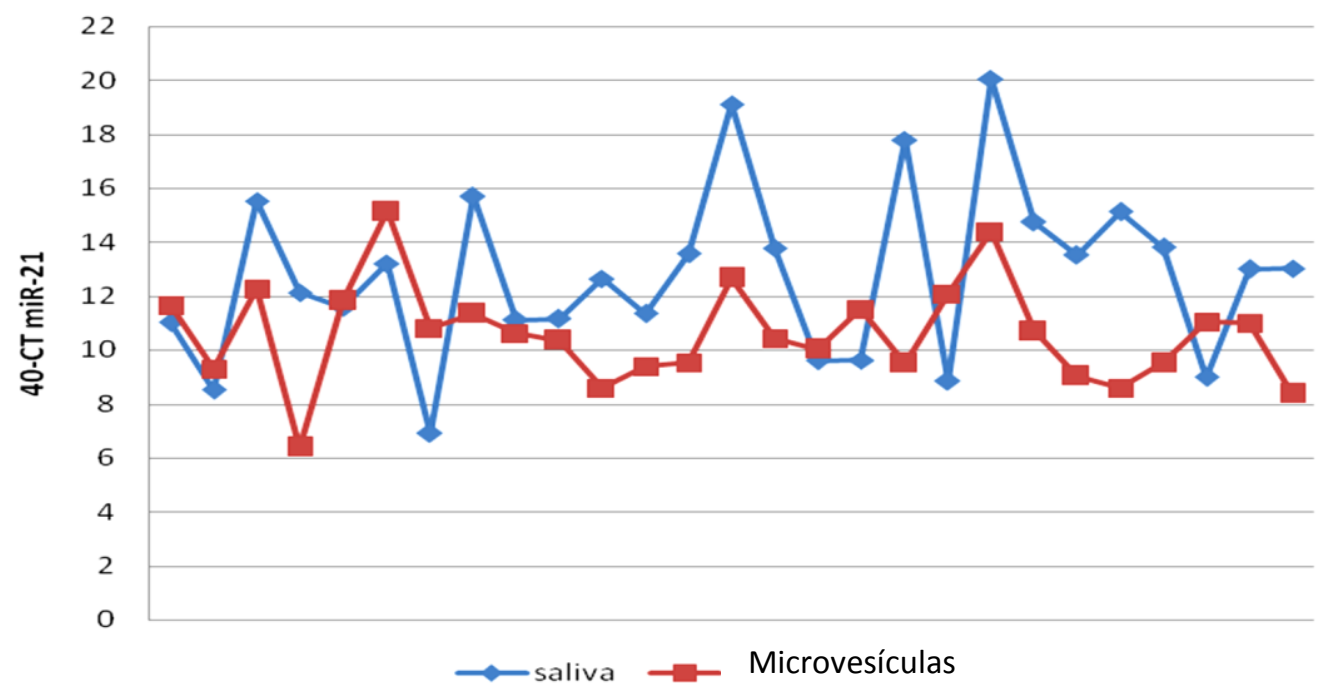

Figura 26 - Comparação dos valores de Ciclo Treshould (Ct) do miR-21-5p entre saliva total e Mvs separadas por ultracentrifugação. 


\section{5 - DISCUSSÃO}

O CEC de cavidade oral e orofaringe é um problema de saúde relevante no Brasil e no mundo devido a sua incidência e taxas de sobrevida insatisfatórias. A compreensão dos mecanismos envolvidos na resistência ao tratamento bem como a descoberta de marcadores que possam indicar benefício à QRT, tendo em vista a toxicidade desse tratamento, é um grande desafio. Apesar do vasto número de publicações de biomarcadores em CEC de cavidade oral e orofaringe não temos um marcador que possa ser usado na prática clínica. Os dados de expressão de genes e micrornas são muitas vezes conflitantes, sendo necessários mais estudos nesse contexto visto que esses mecanismos ainda precisam ser melhores elucidados no CEC de cavidade oral e orofaringe. Além disso, ainda são poucos os trabalhos que avaliaram microRNAs em saliva desse grupo de pacientes, principalmente no grupo de pacientes inoperáveis tratados com QRT.

Recrutamos ao todo 28 voluntários sadios e 70 pacientes. Apesar de não termos conseguido completar a casuística proposta (120 pacientes) consideramos que o número alcançado foi satisfatório tendo em vista que esse estudo tem natureza exploratória e levando em consideração o tempo de realização do projeto. É importante ressaltar que mesmo monitorando as agendas médicas essa casuística não representa a totalidade de pacientes nessas condições clínicas atendidos no ICESP, tivemos perdas na identificação e na inclusão de pacientes elegíveis a esse estudo. Pacientes que eram encaminhados para tratamento com quimio neoadjuvante logo após a primeira consulta na Instituição e pacientes com recidiva da doença que eram encaminhados para o segundo tratamento antes de retornarem em consulta, foram frequentemente perdidos, pois não tínhamos tempo hábil para identificarmos esse paciente através dos prontuários antes que eles iniciassem o tratamento.

Um dos critérios de exclusão de paciente foi a presença de sagramento tumoral. Tendo em vista a presença de microRNAs circulantes no sangue, não sabemos qual seria o impacto da contaminação da saliva com esse fluido. Além disso, a hemólise é um inibidor de microRNAs o que poderia gerar problemas na qualidade da amostra.

Outro fator que impossibilitou a inclusão de pacientes foi a intensa xerostomia, sensação de boca seca, dos pacientes. A radioterapia na região de cabeça e pescoço tem como um dos principais efeitos colaterais a xerostomia. O tecido das glândulas salivares 
é altamente susceptível a dano por radiação, sendo a glândula parótida a mais sensível (Scully et al., 1996; Epstein et al., 1992). O dano é proporcional às doses de radiação, sendo que as doses usadas no tratamento de CEC de cavidade oral e orofaringe, 70Gy, pode levar ao declínio de até $95 \%$ do fluxo salivar durante a primeira semana de radiação. O fluxo salivar raramente recupera-se totalmente, geralmente ocorre uma hipertrofia compensatória por parte das glândulas não irradiadas após alguns meses ou até anos, levando a um alívio da sensação de boca seca (Epstein et al., 1996). Em nossa casuística a xerostomia foi um sintoma frequentemente referido pelos pacientes já tratados com QRT, tanto os pacientes com recidiva da doença quanto os pacientes do grupo livre de doença pós tratamento, sendo que em 10 pacientes não foi possível fazermos a coleta devido a completa ausência de saliva. Além desses pacientes que tentamos incluir houve vários outros identificados que nós nem abordamos para inclusão, pois estava descrito no prontuário que o paciente sofria de intensa xerostomia fazendo inclusive uso de saliva artificial para aliviar o sintoma.

Os pacientes que estavam debilitados e optamos por não incluir foram casos em que o paciente chegou em cadeira de rodas fazendo uso de $\mathrm{O} 2$ ou que os pacientes tinham dor tumoral localizada tão forte que tinham dificuldade inclusive para falar. Visando o bem-estar desses pacientes e para não causarmos um desconforto ainda maior para os mesmos optamos por não incluí-los.

A mediana de idade dos pacientes ao diagnóstico e do grupo controle são próximas, sendo que tivemos uma porcentagem maior de mulheres no grupo controle. A porcentagem de tabagistas foi maior nos grupos de pacientes do que no grupo controle, sendo que a carga tabagica de fumantes e ex-fumantes também foi maior entre os pacientes (mediana de 40 maços/ano (13-100 maços/ano) qaundo comparado aos voluntários sadios (mediana 10 maços/ano (1-80 maços/ano, 1 usuário de caximbo). É importante ressaltarmos também a diferença do etilismo entre os pacientes e controles, visto que a maioria dos etilistas no grupo controle é etilista social e entre os pacientes há história de etilismo severo.

Analisamos a expressão relativa de 8 microRNAs, miR-15a-5p, miR-21-5p, miR-23a-3p, miR-125b-5p, miR-142-3p, miR-200b-3p, miR-296-5p e miR-503-5p além dos normalizadores miR-16-5p e U6 snRNA e o Spike-in 6 (Sp6). Para análise de expressão gênica consideramos 26 amostras do grupo controle (G0), 30 amostras de 
pacientes antes do tratamento $(\mathrm{G} 1), 8$ de pacientes com falha de tratamento $(\mathrm{G} 2)$ e 21 amostras de pacientes livres de doença (G3).

Testamos o miR-16-5p e o U6snRNA para serem usados como normalizador e optamos por usar o miR-16-5p pois não apresentou diferença significativa entre os grupos de estudo, ao contrário do U6snRNA. A normalização para os ensaios de qPCR em fluidos é uma das causas dos diferentes resultados encontrados nos trabalhos. Os normalizadores mais utilizados na literatura para estudo em tumores de cabeça e pecoço são os pequenos RNAs nucleares (snRNAs) como RNU44, RNU48, RNU43, e RNU6B e os microRNAs endógenos como Let-7a, miR-16 e miR-191 (Peltier et al., 2008). Porém os snRNAs são associados a diversos fatores clínico-patológico e até mesmo a sobrevida, o que torna seu uso um viés (Gee et al., 2011). O U6snRNA é parte de uma pequena ribonucleoproteína nuclear, um componente do spliceossomo sobre o qual o splicing do pre-mRNA ocorre.

Apesar do miR-503-5p estar envolvido nos mecanismos de resistência a cisplatina em amostras tumor de pulmão de pequenas células (Qiu et al., 2013) e na transição epitélio mesênquima em osteossarcoma (Guo et al., 2010) ele foi indetectável na maioria das amostras de saliva de nosso grupo de estudo. O mesmo ocorreu com o miR-296-5p que foi associado a resistência a radioterapia e recidiva tumoral em tumor de pulmão de pequenas células (Maia et al., 2015)

A expressão do mir-15a-5p foi maior no grupo com falha de tratamento do que em qualquer outro grupo, tendo sido diferencialmente significativo quando comparado aos grupos controle e livre de doença. Sun et al, (2012) demostrou em linhagens de carcinoma de língua que a alta expressão do miR-15 foi associada a sensibilidade ao tratamento com cisplatina e pior sobrevida dos pacientes.

A expressão do miR-21-5p foi menor nos voluntários sadios do que em qualquer grupo de pacientes, sendo que há diferença estatisticamente significativa quando comparado aos pacientes sem tratamento prévio e livre de doença. $\mathrm{O}$ miR-21 tem sua expressão aumentada em vários carcinomas, inclusive em CECP onde também tem sido correlacionado com pior sobrevida (Avissar et al., 2009; Selcuklu et al., 2009; Childs et al., 2009; Manikadan et al., 2015; Ramdas et al., 2009; Boldrup et al., 2012; Hui et al., 2012). Esse aumento de expressão também foi encontrado em plasma e saliva de 
pacientes com CECP e plasma de CEC de esôfago quando comparado a indivíduos sadios (Chang et al., 2008; Zahran et al., 2015; Xie et al., 2013). A expressão aumentada em câncer de língua foi associada com baixos níveis de TPM1 e PTEN, atuando como um fator antiapoptótico (Li et al., 2009). A perda do PTEN esta associada com diminuição de E-caderina em CECP, o que está associado com recidiva da doença e morte em CEC de orofaringe (Liu et al., 2010; Zhao et al., 2012). Outro alvo que vem sido atribuído ao miR-21 em CEC de cavidade oral é o PDCD4 (Morte Celular Programada 4) (Ramdas et al., 2009), esse gene foi recentemente identificado como um supressor tumoral e a perda da sua função foi encontrada em linhagens celulares de diversos tipos tumorais (Gao et al., 2007). Devido ao grande número de publicações que encontraram o miR-21 superexpresso em tumores ele foi o primeiro microRNA a ser chamado de oncomir (Sethi et al., 2014) e a análise da sua expressão tem sido sugerida como marcador diagnostico para CCP (Li et al., 2009; Ye et al., 2014). A identificação da maior expressão do mir-21 nas nossas amostras corrobora a importância do miR-21 na carcinogênese do CECP.

No grupo de pacientes sem tratamento prévio, o miR-21-5p teve maior expressão nos pacientes tabagistas e etilistas quando comparados aos pacientes extabagistas e ex-etilistas (cessado o uso há pelo menos 1 ano antes da coleta das amostras) assim como o miR-200b-3p foi mais expresso nos etilista, reforçando a relação dos principais fatores de risco para desenvolvimento de CEC de cavidade e orofaringe com alterações moleculares que contribuem para a carcinogênese. Outros microRNAs como o miR-155 e miR-145 também foram relacionados ao tabaco em pacientes com CEC de cavidade oral (Manikandan et al., 2015; Pal et al., 2013) demonstrando a influência do tabagismo com expressões aberrantes de microRNAs associados a carcinogênese da cavidade oral e orofaringe. Que seja do nosso conhecimento, esse é o primeiro trabalho a correlacionar a expressão do miR-21-5p com tabagismo e etilismo.

O miR-23a-3p teve maior expressão nos grupos sem tratamento prévio e com falha de doença em relação ao grupo de voluntários sadios, além disso, sua expressão foi maior em pacientes com pior sobrevida global. A expressão do miR-23a tem sido relacionada a resistência ao tratamento quimioterápico. Sua expressão está aumentada em linhagens de CEC de língua resistentes à cisplatina (Yu et al., 2010; Scapoli at al., 2010). Além de inibir o PTEN, em carcinoma de língua o miR-23a induz TWIST1 e 
aumento da atividade JNK, controlando assim a transição epitélio-mesênquima e diminuindo a apoptose induzida por cisplatina. Em CCP, a expressão de TWIST é positivamente correlacionada com metástases, metástases em linfonodo e estadiamento clínico (Ou et al., 2008; Zeisberg e Neilson., 2009).

O miR-125b tem sido descrito com expressão diminuída em amostras tumorais de CECP (Boldrup et al., 2012; Hui et al., 2012), indicando que possui função de supressor tumoral (Nakanishi et al., 2014). Em linhagens celulares de carcinoma de cavidade oral ele foi associado com redução da taxa de proliferação e aumento da radiossensibildade por inibir ICAM2, além ter sido associado ao estadiamento tumoral e sobrevida (Shiiba et al., 2016). Ele regula a apoptose por inibir a expressão do lin28 que por sua vez inibe o let-7a-5p, que inibe RAS. Membros da família let-7 estão reduzidos em HNSCC (Childs et al., 2009), eles regulam a atividade do RAS e diversos outro genes relacionados ao ciclo celular (Johnson et al., 2005; Johnson et al., 2007). Ao contrário do que tem sido encontrado em amotras de tumor, no plasma de pacientes com CEC de cavidade oral, o miR-125b está aumentado nos pacientes em relação aos controles (Gu et al., 2015). Indicando que para esse microRNA a expressão pode ser diferente no tecido e nos fluidos biologicos. Cinpolat et al., 2016 avaliou a expressão de oito microRNAs em voluntários sadios, lesões benignas e tumores de glândulas salivares em tecido, plasma e saliva. Ele não encontrou correspondência na expressão dos micros nos 3 materiais biológicos (Cinpolat et al., 2016).

O miR-142-3p teve menor expressão no grupo controle em relação aos demais grupos tendo alcançado diferença significamente estatística apenas em relação aos pacientes sem tratamento prévio. Concordante com nossos dados, o miR-142-3p é mais expresso em CECP comparado a mucosa normal adjacente (Hui et al., 2012; Cervigne et al., 2009; Manikandan et al., 2016) e também no plasma comparado a indíviduos saudáveis, onde sua expressão foi associada com pior prognóstico (Summerer et al., 2015). Porém esa diferença de expressão não foi encontrada por Park et al., 2009.

Já o miR-200b-3p teve maior expressão no grupo de pacientes livre de doença em relação ao grupo controle e ao grupo com falha de tratamento. Apesar de não termos encontrado diferença entre os grupos controle e pacientes sem tratamento prévio, o miR-200b já foi descrito com menor expressão em CEC de cavidade oral e orofaringe comparada a controles (Brito et al., 2016). A baixa expressão do mir-200b em tumores de língua foi associada resistência à quimioterapia, metástases e menor sobrevida 
através da regulação do BMI1 (Sun et al., 2012). Ele tem sido descrito com menor expressão na resistência a cisplatina em diversos tumores. Em câncer gástrico ele está associado à regulação da transição epitélio-mesenquima e migração da célula tumoral pela inibição da expressão do ZEB2 e aumento de E-caderina (Kurashige et al., 2012). Além do ZEB2 também possui como alvos o BCL2 e XIAP, inibidores de apoptose (Zhu et al., 2012) e o E2F3. O XIAP também está relacionado a propriedades steam cell. Em nosso trabalho, o miR-200b-3p ( $\mathrm{p}=0,013)$ foi associado ao etilismo.

Os microRNAs estudados não foram diferencialmente expressos em relação aos parâmetros clínicos e nem em relação a resposta inicial e a longo prazo (falha de tratamento e status global) desses pacientes ao tratamento.

Com relação à sobrevida livre de progressão, os micros miR-15a-5p, miR-125b5p, e miR-142-3p foram associados sobrevida livre de progressão. Os pacientes com menor expressão desses microRNAs apresentaram uma tendência de pior sobrevida que os pacientes com expressão aumentada para esses micros. Na sobrevida global também não atingiram significância estatística, porém é possível notar que os pacientes com menor expressão do miR-125b-5p e alta expressão do miR-23a-3p apresentam uma tendência de pior sobrevida.

E importante ressaltar que ainda não temos um tempo de seguimento muito grande desses pacientes, sendo que como os pacientes foram sendo incluídos ao longo do trabalho esse seguimento é muito variável. O primeiro paciente incluído terminou o tratamento em junho de 2013 tendo então 3 anos de seguimento, a maioria do pacientes (28) terminaram o tratamento até dezembro de 2014, tendo esses 1 ano e 5 meses de seguimento e temos dois pacientes que terminaram o tratamento no início de 2016 . O menor tempo de seguimento de sobrevida global é 5,9 meses e o maior é de 34,10 meses.

Dos 14 pacientes que foram a óbito nesse grupo de estudo, apenas 1 morte não foi relacionada ao câncer e 1 paciente faleceu em decorrência de um segundo tumor primário na cavidade oral, os demais foram a óbito em decorrência de recidiva ou progressão da doença primária. Não foi possível avaliar os parâmetros de resposta de sete pacientes desse grupo: 1 paciente ainda não fez avaliação de resposta, 3 pacientes 
faleceram antes de terminar o tratamento, 1 paciente teve o tratamento alterado para radioterapia exclusiva e 2 pacientes abandonaram o tratamento e perderam seguimento.

Confirmamos a presença de microvesículas de formato arredondado e tamanho variável (maioria até $175 \mathrm{~nm}$ ) na saliva de pacientes e de voluntários sadios através da ME e NANOSIGHT LM14, mas não encontramos diferença significativa no número absoluto de partículas entre os diferentes grupos avaliados. Diversos trabalhos têm relatado um maior número de partículas de exossomos em amostra tumorais quando comparadas a indivíduos saudáveis em diferentes tumores como ovário, melanoma e glioblastoma (Graves et al., 2004; Skog et al., 2008; Peinado et al., 2012). Porém nem sempre essa diferença é encontrada baseada no número de partículas e sim pelo aumento do conteúdo protéico (CD63, CD9 ou CD81) nas amostras. Pelo ensaio de ELISA encontramos um maior número de partículas marcadas com CD63 no grupo controle quando comparado ao grupo de pacientes sem tratamento prévio.

Gallo et al., 2012 comparou a detecção de micrornas do pellet de exossomos com o sobrenadante depletado de exossomos em saliva e concluiu que 83-99\% dos microRNAs testados (miR-22, miR-202, miR-203 e o miR-1273) estão contidos nos exossomos. O que representa que cada micro tem de 2 a 128 folds de diferença $(2,2-$ 12,5 ciclos) entre exossmo e sobrenadante. Nessa análise, ele obteve a concentração relativa apenas subtraíndo a média dos Cts do exossomo pela média dos Cts do sobrenadante, considerando que a diferença de 1 unidade de $\mathrm{Ct}$ é igual a 2 fold de diferença na concentração inicial de RNA. Se analisarmos nossos dados da mesma maneira a fim de termos parâmetros de comparação com dados da literatura, encontramos que a diferença entre os Cts do exossomo e sobrenadante para o miR-21$5 \mathrm{p}$ foi de 4,25 ciclos, ou seja 8,5 folds de diferença. Apesar de termo dosado microRNAs diferentes do trabalho anterior nós também pudemos observar uma maior concentração do miR-21 dentro dos exossomos do que circulando livremente na saliva, entretanto precisamos ressaltar que quando avaliamos a diferença de Ct para o miR-21 entre microvesículas e saliva total encontramos que a saliva total tem em média 3,3 ciclos a menos que nos exossomos, indicando que também temos a presença do miR21-5p fora de exossomos. É importante ressaltar que outros mecanismos de circulação dos microRNAs, que não intravesiculares têm sido descritos como associados à proteína 
argonauta 2 ou à lipoproteínas que também protegem o microRNAs da degradação (Turchinovich et al., 2013; Chen et al., 2012). 


\section{CONCLUSÕES}

Dos microRNAs avaliados, 5 foram diferencialmente expressos entre os grupos de pacientes, que representam a evolução clínica da doença: miR-21-5p, miR-23a-3p, miR-125-5p, miR-142-3p e miR-200b-3p.

A expressão dos microRNAs: miRs 21-5p, 23a-3p, 125b-5p e 142-3p foi maior na saliva dos pacientes com CEC de cavidade oral e orofaringe em relação aos voluntários sadios, sugerindo que esses microRNAs são potenciais marcadores tumoras em CEC de cavidade oral e orofaringe. Entretanto, novos estudos são necessários para confirmarmos esses achados visto que a expressão de alguns micros ainda é controversa.

Os pacientes tabagistas e/ou etilistas apresentaram maior expressão do miR-21-5p e os etilistas também tiveram maior expressão do miR-200b-3p. O tabagismo é o principal fator de risco para desenvolvimento do CEC de cavidade oral e orofaringe, esse dado reforça a relação dos carcinógenos presentes no cigarro com alterações moleculares que podem levar a carcinogênese.

A expressão dos microRNAs: miR-15a-5p, miR-125b-5p, miR-23a-3p e miR-142-3p parecem estar associadas com sobrevida livre de progressão e sobrevida global, porém é preciso um tempo maior de seguimento desses pacientes para verificarmos se essa relação realmente existe.

Microvesículas foram detectadas e caracterizadas na saliva, sendo que a expressão do miR-21-5p foi predominantemente detectada nas microvesículas em relação ao sobrenadante livre de vesículas. Uma vez que as microvesículas tem um importante papel na comunicação intercelular, a secreção do miR-21 dentro das microvesículas pode ter um importante papel na preparação de nichos pré-metastaticos, recidiva ou até mesmo segundos tumores primários em pacientes com $\mathrm{CEC}$ de cavidade oral $\mathrm{e}$ orofaringe. 


\section{REFERÊNCIAS BIBLIOGRÁFICAS}

Aebi S, Kurdi-Haidar B, Gordon R, Cenni B, Zheng H, Fink D, Christen RD,Boland CR, Koi M, Fishel R, Howell SB. Loss of DNA mismatch repair in acquired resistance to cisplatin. Cancer Res. 1996 Jul 1; 56(13):3087-90.

Alibek K, Kakpenova A, Baiken Y. Role of infectious agents in the carcinogenesis of brain and head and neck cancers. Infect Agent Cancer. 2013 Feb 2; 8(1):7.

Ambros V, Bartel B, Bartel DP, Burge CB, Carrington JC, Chen X, Dreyfuss G,Eddy SR, Griffiths-Jones S, Marshall M, Matzke M, Ruvkun G, Tuschl T. A uniform system for microRNA annotation. RNA. 2003 Mar;9(3):277-9.

Ameres SL, Zamore PD. Diversifying microRNA sequence and function. Nat Rev MolCell Biol. 2013 Aug;14(8):475-88.

Argiris A, Karamouzis MV, Raben D, Ferris RL. Head and neck cancer. Lancet. 2008;371(9625):1695-709.

Arora H, Qureshi R, Jin S, Park AK, Park WY. miR-9 and let-7g enhance the sensitivity to ionizing radiation by suppression of NFkB1. Exp Mol Med. 2011 May 31;43(5):298-304.

Arscott W, Camphausen K. EGFR isoforms in exosomes as a novel method for biomarker discovery in pancreatic cancer. Biomark Med 2011; 5:821.

Avissar M, McClean MD, Kelsey KT, Marsit CJ. MicroRNA expression in head and neck cancer associates with alcohol consumption and survival. Carcinogenesis. 2009 Dec;30(12):2059-63.

Bădulescu F, Crişan A, Bădulescu A, Schenker M. Recent data about the role of human papillomavirus (HPV) in oncogenesis of head and neck cancer. Rom J Morphol Embryol. 2010;51(3):437-40.

Baietti MF, Zhang Z, Mortier E, Melchior A, Degeest G, Geeraerts A, Ivarsson Y, Depoortere F, Coomans C, Vermeiren E, Zimmermann P, David G. Syndecan-syntenin-ALIX regulates the biogenesis of exosomes. Nat Cell Biol. 2012 Jun 3;14(7):677-85.

Bartel DP. MicroRNAs: genomics, biogenesis, mechanism, and function. Cell 2004; 116:281297.

Bartel DP. MicroRNAs: target recognition and regulatory functions. Cell. 2009 Jan 23;136(2):215-33.Review.

Begg AC. Cisplatin and radiation: interaction probabilities and therapeutic possibilities. Int $J$ Radiat Oncol Biol Phys. 1990 Nov; 19(5):1183-9. Review.

Behm-Ansmant I, Rehwinkel J, Doerks T, Stark A, Bork P, Izaurralde E. mRNA degradation by miRNAs and GW182 requires both CCR4:NOT deadenylase and DCP1:DCP2 decapping complexes. Genes Dev. 2006 Jul 15;20(14):1885-98.

Bell ML, Buvoli M, Leinwand LA. Uncoupling of expression of an intronic microRNA and its myosin host gene by exon skipping. Mol Cell Biol. 2010 Apr;30(8):1937-45. 
Bennett CB, Lewis AL, Baldwin KK, Resnick MA. Lethality induced by a single site-specific double-strand break in a dispensable yeast plasmid. Proc Natl Acad Sci USA. 1993 Jun 15; 90(12):5613-7.

Boldrup L, Coates PJ, Wahlgren M, Laurell G, Nylander K. Subsite-based alterations in miR21 , miR-125b, and miR-203 in squamous cell carcinoma of the oral cavity and correlation to important target proteins. J Carcinog. 2012;11:18.

Bonilla-Velez J, Mroz EA, Hammon RJ, et al. Impact of human papillomavirus on oropharyngeal cancer biology and response to therapy: implications for treatment. Otolaryngol Clin North Am 2013;46(4):521-43.

Brito BL, Lourenço SV, Damascena AS, Kowalski LP, Soares FA, Coutinho-Camillo CM. Expression of stem cell-regulating miRNAs in oral cavity and oropharynx squamous cell carcinoma. J Oral Pathol Med. 2016 Feb 3.

Brizel DM, Esclamado R. Concurrent chemoradiotherapy for locally advanced, nonmetastatic, squamous carcinoma of the head and neck: consensus, controversy, and conundrum. J Clin Oncol 2006; 24(17):2612e2617.

Brown R, Hirst GL, Gallagher WM, McIlwrath AJ, Margison GP, van der Zee AG, Anthoney DA. hMLH1 expression and cellular responses of ovarian tumour cells to treatment with cytotoxic anticancer agents. Oncogene. 1997 Jul 3; 15(1):45-52.

Butz K, Geisen C, Ullmann A, Spitkovsky D, Hoppe-Seyler F. Cellular responses of HPVpositive cancer cells to genotoxic anti-cancer agents: repression of E6/E7-oncogene expression and induction of apoptosis. Int J Cancer. 1996 Nov 15;68(4):506-13.

Calin GA, Dumitru CD, Shimizu M, Bichi R, Zupo S, Noch E, Aldler H, Rattan S, Keating M, Rai K, Rassenti L, Kipps T, Negrini M, Bullrich F, Croce CM. Frequent deletions and downregulation of micro-RNA genes miR15 and miR16 at 13q14 in chronic lymphocytic leukemia. Pro cNatl Acad Sci USA 2002; 99:15524-15529.

Cancer Genome Atlas Network. Comprehensive genomic characterization of head and neck squamous cell carcinomas. Nature. 2015 Jan 29;517(7536):576-82. doi:10.1038/nature14129.

Castro Júnior, Gilberto de. Carcinoma epidermoide de cabeça e pescoço localmente avançado. ver Bras Med; 67(esp.3)set. 2010.

Cepeda V, Fuertes MA, Castilla J, Alonso C, Quevedo C, Pérez JM. Biochemical mechanisms of cisplatin cytotoxicity.Anticancer Agents Med Chem. 2007 Jan;7(1):3-18. Review.

Cervigne NK, Reis PP, Machado J, Sadikovic B, Bradley G, Galloni NN, Pintilie M, Jurisica I, Perez-Ordonez B, Gilbert R, Gullane P, Irish J, Kamel-Reid S. Identification of a microRNA signature associated with progression of leukoplakia to oral carcinoma. Hum Mol Genet. 2009 Dec 15;18(24):4818-29.

Chen X, Ba Y, Ma L, Cai X, Yin Y, Wang K, Guo J, Zhang Y, Chen J, Guo X, Li Q,Li X, Wang W, Zhang Y, Wang J, Jiang X, Xiang Y, Xu C, Zheng P, Zhang J, Li R,Zhang H, Shang $X$, Gong T, Ning G, Wang J, Zen K, Zhang J, Zhang CY. Characterization of microRNAs in serum: a novel class of biomarkers for diagnosis of cancer and other diseases. Cell Res. 2008 Oct; 18(10):997-1006. 
Chen Y, Zuo J, Liu Y, Gao H, Liu W. Inhibitory effects of miRNA-200c on chemotherapyresistance and cell proliferation of gastric cancer SGC7901/DDP cells. Chin J Cancer. 2010 Dec; 29 (12):1006-11.

Chendrimada TP, Finn KJ, Ji X, Baillat D, Gregory RI, Liebhaber SA, Pasquinelli AE, Shiekhattar R. MicroRNA silencing through RISC recruitment of eIF6. Nature. 2007 Jun 14;447(7146):823-8.

Chiappin S, Antonelli G, Gatti R, De Palo EF. Saliva specimen: a new laboratory tool for diagnostic and basic investigation. Clin Chim Acta. 2007 Aug; 383(1-2):30-40. Review.

Childs G, Fazzari M, Kung G, Kawachi N, Brandwein-Gensler M, McLemore M, Chen Q, Burk RD, Smith RV, Prystowsky MB, Belbin TJ, Schlecht NF. Low-level expression. of microRNAs let-7d and miR-205 are prognostic markers of head and neck squamous cell carcinoma. Am J Pathol. 2009 Mar;174(3):736-45.

Chun-Zhi Z, Lei H, An-Ling Z, Yan-Chao F, Xiao Y, Guang-Xiu W, Zhi-Fan J, Pei-Yu P, Qing-Yu Z, Chun-Sheng K. MicroRNA-221 and microRNA-222 regulate gastric carcinoma cell proliferation and radioresistance by targeting PTEN. BMC Cancer. 2010 Jul 12; 10: 367.

Cinpolat O, Unal ZN, Ismi O, Gorur A, Unal M. Comparison of microRNA profiles between benign and malignant salivary gland tumors in tissue, blood and saliva samples: a prospective, case-control study. Braz J Otorhinolaryngol. 2016 Apr 27.

Coatesworth AP, Tsikoudas A, MacLennan K. The cause of death in patients with head and neck squamous cell carcinoma.J Laryngol Otol. 2002 Apr; 116(4):269-71.Review.

Cocucci E, Racchetti G, Meldolesi J. Shedding microvesicles: artefacts no more. Trends Cell Biol. 2009 Feb;19 (2):43-51. Review

Corcoran C, Friel AM, Duffy MJ, Crown J, O'Driscoll L. Intracellular and extracellular microRNAs in breast cancer. Clin Chem. 2011 Jan;57(1):18-32.

Corry J, Peters LJ, Rischin D. Optimising the therapeutic ratio in head andneck cancer.Lancet Oncol. 2010 Mar;11(3):287-91. Review.

Coste F, Malinge JM, Serre L, Shepard W, Roth M, Leng M, Zelwer C. Crystal structure of a double-stranded DNA containing a cisplatin interstrand cross-link at 1.63 A resolution: hydration at the platinated site. Nucleic Acids Res. 1999 Apr 15;27(8):1837-46.

De Castro G Jr, Pasini FS, Siqueira SA, Ferraz AR, Villar RC, Snitcovsky IM, Federico MH. ERCC1 protein, mRNA expression and T19007C polymorphism as prognostic markers in head and neck squamous cell carcinoma patients treated with surgery and adjuvant cisplatin-based chemoradiation. Oncol Rep. 2011 Mar; 25(3): 693-9.

Di Leva G, Garofalo M, Croce CM. MicroRNAs in cancer.Annu Rev Pathol.2014;9:287314.Review.

Domenge $\mathrm{C}$, Hill $\mathrm{C}$, Lefebvre $\mathrm{J}$ et al. Randomized trial of neoadjuvant chemotherapy in oropharyngeal carcinoma.Br J Cancer.2000; 83:1594-8.

D'Souza G, Kreimer AR, Viscidi R, Pawlita M, Fakhry C, Koch WM, et al. Case-control study of human papillomavirus and oropharyngeal cancer. N Engl J Med. 2007; 356(19):1944-56. 
D'Souza-Schorey C, Clancy JW. Tumor-derived microvesicles: shedding light on novel microenvironment modulators and prospective cancer biomarkers. Genes Dev. 2012 Jun 15;26(12):1287-99. Review.

El-Naggar AK, Hurr K, Luna MA, Goepfert H, Hong WK, Batsakis JG. Intratumoral genetic heterogeneity in primary head and neck squamous carcinoma using microsatellite markers. Diagn Mol Pathol. 1997 Dec;6(6):305-8.

Epstein JB, Stevenson-Moore P, Scully C. Management of xerostomia. J Can Dent Assoc. 1992 Feb;58(2):140-3. Review.

Epstein JB, van der Meij EH, Lunn R, Stevenson-Moore P. Effects of compliance with fluoride gel application on caries and caries risk in patients after radiation therapy for head and neck cancer. Oral Surg Oral Med Oral Pathol Oral Radiol Endod. 1996 Sep;82(3):268-75.

Fader CM, Colombo MI. Multivesicular bodies and autophagy in erythrocyte maturation.Autophagy.2006; 2:122-125.

Feng D, Zhao WL, Ye YY, Bai XC, Liu RQ, Chang LF, Zhou Q, Sui SF. Cellular internalization of exosomes occurs through phagocytosis. Traffic. 2010 May; 11(5):675-87.

Ferlay J, Soerjomataram I, Dikshit R, Eser S, Mathers C, Rebelo M, Parkin DM, Forman D, Bray F. Cancer incidence and mortality worldwide: sources, methods and major patterns in GLOBOCAN 2012. Int J Cancer. 2015 Mar 1;136(5):E359-86.

Fink D, Aebi S, Howell SB. The role of DNA mismatch repair in drug resistance. Clin Cancer Res. 1998 Jan; 4(1):1-6. Review

Fitzner D, Schnaars M, van Rossum D, Krishnamoorthy G, Dibaj P, Bakhti M, Regen T, Hanisch UK, Simons M. Selective transfer of exosomes from oligodendrocytes to microglia by macropinocytosis. J Cell Sci. 2011 Feb 1; 124 (Pt 3):447-58.

Forastiere AA, Trotti A. Radiotherapy and concurrent chemotherapy: a strategy that improves locoregional control and survival in oropharyngeal cancer. J Natl Cancer Inst. 1999 Dec 15; 91(24): 2065-6.

Fu X, Tian J, Zhang L, Chen Y, Hao Q. Involvement of microRNA-93, a new regulator of PTEN/Akt signaling pathway, in regulation of chemotherapeutic drug cisplatin chemosensitivity in ovarian cancer cells.FEBS Lett. 2012 May z;586(9):1279-86.

Fuertes MA, Alonso C, Pérez JM. Biochemical modulation of Cisplatin mechanisms of action: enhancement of antitumor activity and circumvention of drug resistance. Chem Rev. 2003 Mar;103(3):645-62. Review.

Fury MG, Pfister DG. Current recommendations for systemic therapy of recurrentand/or metastatic head and neck squamous cell cancer. J Natl Compr Canc Netw. 2011 Jun 1;9(6):6819.

Galluzzi L, Senovilla L, Vitale I, Michels J, Martins I, Kepp O, CastedoM,Kroemer G. Molecular mechanismsofcisplatinresistance. Oncogene. 2012 Apr 12; 31(15):1869-83. 
Ganci F, Sacconi A, Manciocco V, Sperduti I, Battaglia P, Covello R, Muti P, Strano S, Spriano G, Fontemaggi G, Blandino G. MicroRNA expression as predictor of local recurrence risk in oral squamous cell carcinoma. Head Neck. 2016 Apr;38 Suppl 1:E189-97.

Gao F, Zhang P, Zhou C, Li J, Wang Q, Zhu F, Ma C, Sun W, Zhang L. Frequent loss of PDCD4 expression in human glioma: possible role in the tumorigenesis of glioma. Oncol Rep. $2007 \mathrm{Jan} ; 17(1): 123-8$.

Gasco M, Crook T. The p53 network in head and neck cancer. Oral Oncol. 2003 Apr;39(3):22231. Review.

Ge R, Tan E, Sharghi-Namini S, Asada HH. Exosomes in Cancer Microenvironmentand Beyond: have we Overlooked these Extracellular Messengers? Cancer Microenviron. 2012 Dec;5(3):323-32.

Gee HE, Buffa FM, Camps C, Ramachandran A, Leek R, Taylor M, Patil M, Sheldon H, Betts G, Homer J, West C, Ragoussis J, Harris AL. The small-nucleolar RNAs commonly used for microRNA normalisation correlate with tumour pathology and prognosis. Br J Cancer. 2011 Mar 29;104(7):1168-77.

Gonzalez VM, Fuertes MA, Alonso C, Perez JM. Is cisplatin-induced cell death always produced by apoptosis? Mol Pharmacol. 2001 Apr; 59(4):657-63. Review.

Gonzalez-Begne M, Lu B, Han X, Hagen FK, Hand AR, Melvin JE, Yates JR. Proteomic analysis of human parotid gland exosomes by multidimensional protein identification technology (MudPIT). J Proteome Res. 2009 Mar;8(3):1304-14.

Götte K, Schäfer C, Riedel F, Arens N, Hörmann K. Intratumoral genomic heterogeneity in primary head and neck cancer and corresponding metástases detected by dual-FISH. Oncol Rep. 2004 Jan;11(1):17-23.

Gottesman, M. M., Fojo, T., Bates, S. E., 2002. Multi drug resistance in cancer: role of ATPdependent transporters. Nat.Rev.Cancer 2, 48-58.

Grant R, Ansa-Addo E, Stratton D, Antwi-Baffour S, Jorfi S, Kholia S, Krige L,Lange S, Inal J. A filtration-based protocol to isolate human plasma membrane-derived vesicles and exosomes from blood plasma.J Immunol Methods. 2011 Aug 31;371(1-2):143-51.

Graves LE, Ariztia EV, Navari JR, et al. Proinvasive properties of ovarian cancer ascitesderived membrane vesicles.Cancer Res 2004; 64:7045-7049.

Griffiths-Jones S, Saini HK, van Dongen S, Enright AJ. miRBase: tools for microRNA genomics. Nucleic Acids Res. 2008 Jan;36(Database issue):D154-8.

Gruenberg J, van der Goot FG. Mechanisms of pathogen entry through the endosomal compartments.Nat Rev Mol Cell Biol. 2006 Jul; 7(7): 495-504. Review.

Gu WL, Ye DX, Wu JJ. [Expression and clinical significance of plasma microRNA-125b level in patients with oral squamous cell carcinoma]. Shanghai Kou Qiang Yi Xue. 2015 Feb;24(1):71-5.

Guo H, Ingolia NT, Weissman JS, Bartel DP. Mammalian microRNAs predominantly act to decrease target mRNA levels. Nature. 2010 Aug 12; 466(7308):835-40. Zhong X, Li N, Liang 
S, Huang Q, Coukos G, Zhang L. Identification of microRNAs regulating reprogramming factor LIN28 in embryonic stem cells and cancer cells. J Biol Chem. 2010 Dec 31;285(53):41961-71.

György B, Szabó TG, Pásztói M, Pál Z, Misják P, Aradi B, László V, Pállinger E, Pap E, Kittel A, Nagy G, Falus A, Buzás EI. Membrane vesicles, current state-of-the-art: emerging role of extracellular vesicles. Cell Mol Life Sci. 2011 Aug;68(16):2667-88. Review.

Hamano R, Miyata H, Yamasaki M, Kurokawa Y, Hara J, Moon JH, Nakajima K, Takiguchi S, Fujiwara Y, Mori M, Doki Y. Overexpression of miR-200c induces chemoresistance in esophageal cancers mediated through activation of the Akt signaling pathway. Clin Cancer Res. 2011 May 1;17(9):3029-38.

Han J, Lee Y, Yeom KH, Kim YK, Jin H, Kim VN. The Drosha-DGCR8 complex in primary microRNA processing.Genes Dev. 2004 Dec 15;18(24):3016-27.

Handra-Luca A, Hernandez J, Mountzios G, Taranchon E, Lacau-St-Guily J, Soria JC, Fouret P. Excision repair cross complementation group 1 immunohistochemical expression predicts objective response and cancer-specific survival in patients treated by Cisplatin-based induction chemotherapy for locally advanced head and neck squamous cell carcinoma. Clin Cancer Res. 2007 Jul 1; 13(13):3855-9.

Harrison P, Dragovic R, Albanyan A, Lawrie AS, Murphy M, Sargent I. Application of dynamic light scattering to the measurement of microparticles. J Thromb Haemost 2009; 7 (Suppl. 2): OC-TU-056

Heck JE, Berthiller J, Vaccarella S, Winn DM, Smith EM, Shan'gina O, et al. Sexual behaviours and the risk of head and neck cancers: a pooled analysis in the International Head and Neck Cancer Epidemiology (INHANCE) consortium. Int J Epidemiol. 2010;39(1):166-81.

Hocking JS, Stein A, Conway EL, Regan D, Grulich A, Law M, et al. Head and neck cancer in Australia between 1982 and 2005 show increasing incidence of potentially HPV-associated oropharyngeal cancers. Br J Cancer. 2011;104(5):886-91.

Hui AB, Lenarduzzi M, Krushel T, Waldron L, Pintilie M, Shi W, Perez-Ordonez B, Jurisica I, O'Sullivan B, Waldron J, Gullane P, Cummings B, Liu FF. Comprehensive MicroRNA profiling for head and neck squamous cell carcinomas. Clin Cancer Res. 2010 Feb 15;16(4):1129-39.

Hutvágner G, McLachlan J, Pasquinelli AE, Bálint E, Tuschl T, Zamore PD. A cellular function for the RNA-interference enzyme Dicer in the maturation of the let-7 small temporal RNA.Science. 2001 Aug 3;293(5531):834-8.

Imanaka Y, Tsuchiya S, Sato F, Shimada Y, Shimizu K, Tsujimoto G. MicroRNA-141 confers resistance to cisplatin-induced apoptosis by targeting YAP1 in human esophageal squamous cell carcinoma. J Hum Genet. 2011 Apr;56(4):270-6.

Instituto Nacional de Câncer José de Alencar Gomes da Silva (INCA). Estimativa 2016: Incidência de Câncer no Brasil. Rio de Janeiro, 2015. Disponível em: http://www.inca.gov.br/estimativa/2016/estimativa-2016-v11.pdf. Acesso em 28 de março de 2016.

Jamieson ER, Lippard SJ. Structure, Recognition, and Processing of Cisplatin-DNA Adducts. Chem Rev. 1999 Sep 8; 99(9):2467-98. 
Johnson SM, Grosshans H, Shingara J, Byrom M, Jarvis R, Cheng A, Labourier E, Reinert KL, Brown D, Slack FJ. RAS is regulated by the let-7 microRNA family. Cell. 2005 Mar 11;120(5):635-47.

Johnson CD, Esquela-Kerscher A, Stefani G, Byrom M, Kelnar K, Ovcharenko D, Wilson M, Wang X, Shelton J, Shingara J, Chin L, Brown D, Slack FJ. The let-7 microRNA represses cell proliferation pathways in human cells. Cancer Res. 2007 Aug 15;67(16):7713-22.

Jung Y, Lippard SJ. Direct cellular responses to platinum-induced DNA damage.Chem Rev. 2007 May;107(5):1387-407. Review.

Kahlert C, Melo SA, Protopopov A, Tang J, Seth S, Koch M, Zhang J, Weitz J, Chin L, Futreal A, Kalluri R. Identification of double-stranded genomic DNA spanning all chromosomes with mutated KRAS and p53 DNA in the serum exosomes of patients with pancreatic cancer. $J$ Biol Chem. 2014 Feb 14;289(7):3869-75.

Kahner BN, Dorsam RT, Kunapuli SP. Role of P2Y receptor subtypes in platelet-derived microparticle generation. Front Biosci. 2008 Jan 1;13:433-9.

Kalyankrishna S, Grandis JR. Epidermal growth factor receptor biology in head and neck cancer. J Clin Oncol. 2006 Jun 10;24(17):2666-72. Review.

Kastl L, Brown I, Schofield AC. miRNA-34a is associated with docetaxel resistance in human breast cancer cells. Breast Cancer Res Treat. 2012 Jan; 131(2):445-54.

Kelland L. The resurgence of platinum-based cancer chemotherapy.Nat Rev Cancer. 2007 Aug;7(8):573-84. Review.

Ketting RF, Fischer SE, Bernstein E, Sijen T, Hannon GJ, Plasterk RH. Dicer functions in RNA interference and in synthesis of small RNA involved in developmental timing in C. elegans. Genes Dev. 2001 Oct 15; 15(20):2654-9.

Khvorova A, Reynolds A, Jayasena SD. Functional siRNAs and miRNAs exhibit strand bias. Cell. 2003 Oct 17;115(2):209-16. Erratum in: Cell. 2003 Nov 14;115(4):505.

Kim MK, Cho KJ, Kwon GY, Park SI, Kim YH, Kim JH, Song HY, Shin JH, Jung HY,Lee GH, Choi KD, Kim SB. Patients with ERCC1-negative locally advanced esophageal cancers may benefit from preoperative chemoradiotherapy. Clin Cancer Res. 2008 Jul; 14(13):4225-31.

Köberle B,Tomicic MT,Usanova S, Kaina B., Cisplatin resistance: preclinical findings and clinical implications. Biochim Biophys Acta.2010 Dec; 1806(2):172-82.

Kozaki K, Imoto I, Mogi S, Omura K, Inazawa J. Exploration of tumor-suppressive microRNAs silenced by DNA hypermethylation in oral cancer. Cancer Res. 2008 Apr 1;68(7):2094-105.

Kumar B, Cordell KG, Lee JS, Worden FP, Prince ME, Tran HH, Wolf GT, Urba SG, Chepeha DB, Teknos TN, Eisbruch A, Tsien CI, Taylor JM, D'Silva NJ, Yang K, Kurnit DM, Bauer JA, Bradford CR, Carey TE. EGFR, p16, HPV Titer, Bcl-xL and p53, sex, and smoking as indicators of response to therapy and survival in oropharyngeal cancer. J Clin Oncol. $2008 \mathrm{Jul}$ 1;26(19):3128-37.

Kurashige J, Kamohara H, Watanabe M, Hiyoshi Y, Iwatsuki M, Tanaka Y, Kinoshita K, Saito $\mathrm{S}$, Baba Y, Baba H. MicroRNA-200b regulates cell proliferation, invasion, and migration by directly targeting ZEB2 in gastric carcinoma. Ann Surg Oncol. 2012 Jul;19 Suppl 3:S656-64. 
Lagos-Quintana M, Rauhut R, Lendeckel W, Tuschl T. Identification of novel genes coding for small expressed RNAs. Science. 2001 Oct 26;294(5543):853-8.

Lambert R, Sauvaget C, de Camargo Cancela M, Sankaranarayanan R. Epidemiology of cancer from the oral cavity and oropharynx. Eur J Gastroenterol Hepatol. 2011;23(8):633-41.

Lamy E, Mau M. Saliva proteomics as an emerging, non-invasive tool to study livestock physiology, nutrition and diseases.J Proteomics. 2012 Jul 19; 75(14):4251-8. Review.

Lázaro-Ibáñez E, Sanz-Garcia A, Visakorpi T, Escobedo-Lucea C, Siljander P,Ayuso-Sacido A, Yliperttula M. Different gDNA content in the subpopulations of prostate cancer extracellular vesicles: apoptotic bodies, microvesicles, and exosomes. Prostate. 2014 Oct;74(14):1379-90.

Lee RC, Feinbaum RL, Ambros V. The C. elegans heterochronic gene lin-4 encodes small RNAs with antisense complementarity to lin-14. Cell. 1993 Dec 3;75(5):843-54.

Lee RC, Ambros V. An extensive class of small RNAs in Caenorhabditis elegans. Science. 2001 Oct 26;294(5543):862-4.

Lee Y, Kim M, Han J, Yeom KH, Lee S, Baek SH, Kim VN. MicroRNA genes are transcribed by RNA polymerase II. EMBO J. 2004 Oct 13;23(20):4051-60.

Lee Y, El Andaloussi S, Wood MJ. Exosomes and microvesicles: extracellular vesicles for genetic information transfer and gene therapy. Hum Mol Genet. 2012 Oct 15;21(R1):R125-34. Review.

Leskelä S, Leandro-García LJ, Mendiola M, Barriuso J, Inglada-Pérez L, Muñoz I, MartínezDelgado B, Redondo A, de Santiago J, Robledo, Hardisson D, Rodríguez-Antona C. The miR200 family controls beta-tubulin III expression and is associated with paclitaxel-based treatment response and progression-free survival in ovarian cancer patients. Endocr Relat Cancer. 2010 Dec 21; 18 (1):85-95.

Li J, Huang H, Sun L, Yang M, Pan C, Chen W, Wu D, Lin Z, Zeng C, Yao Y, Zhang P, Song E. MiR-21 indicates poor prognosis in tongue squamous cell carcinomas as an apoptosis inhibitor. Clin Cancer Res. 2009 Jun 15;15(12):3998-4008.

Liang L, Wong CM, Ying Q, Fan DN, Huang S, Ding J, Yao J, Yan M, Li J, Yao M, Ng IO, He $\mathrm{X}$. MicroRNA-125b suppressesed human liver cancer cell proliferation and metastasis by directly targeting oncogene LIN28B2. Hepatology. 2010 Nov;52(5):1731-40.

Licitra L, Perrone F, Bossi P, Suardi S, Mariani L, Artusi R, Oggionni M, Rossini C, Cantù G, Squadrelli M, Quattrone P, Locati LD, Bergamini C, Olmi P, Pierotti MA, Pilotti S. High-risk human papillomavirus affects prognosis in patients with surgically treated oropharyngeal squamous cell carcinoma. J Clin Oncol. 2006 Dec 20;24(36):5630-6.

Lin J, Liu C, Gao F, Mitchel RE, Zhao L, Yang Y, Lei J, Cai J. miR-200c enhances radiosensitivity of human breast cancer cells. J Cell Biochem. 2013 Mar; 114(3):606-15.

Liu LK, Jiang XY, Zhou XX, Wang DM, Song XL, Jiang HB. Upregulation of vimentin and aberrant expression of E-cadherin/beta-catenin complex in oral squamous cell carcinomas: correlation with the clinicopathological features and patient outcome. Mod Pathol. 2010 Feb;23(2):213-24. 
Liu J, Duan Y. Saliva: A potential media for disease diagnostics and monitoring. Oral Oncol. 2012 Jul; 48(7):569-77.

Liu ZL, Wang H, Liu J, Wang ZX. MicroRNA-21 (miR-21) expression promotes growth, metastasis, and chemo- or radioresistance in non-small cell lung câncer cells by targeting PTEN. Mol Cell Biochem. 2013 Jan;372(1-2):35-45.

Livak KJ, Schmittgen TD. Analysis of relative gene expression data using real-timequantitative PCR and the 2- [Delta][Delta] CTMethod.Methods. 2001 Dec;25(4):402-8

Llave C, Xie Z, Kasschau KD, Carrington JC. Cleavage of Scarecrow-like mRNA targets directed by a class of Arabidopsis miRNA. Science. 2002 Sep 20;297(5589):2053-6.

Long JD, Sullivan TB, Humphrey J, Logvinenko T, Summerhayes KA, Kozinn S, Harty N, Summerhayes IC, Libertino JA, Holway AH, Rieger-Christ KM. A non-invasive miRNA based assay to detect bladder cancer in cell-free urine. Am J Transl Res. 2015 Nov 15;7(11):2500-9. eCollection 2015.

Lorch JH, Goloubeva O, Haddad RI, Cullen K, Sarlis N, Tishler R, et al. Induction chemotherapy with cisplatin and fluorouracil alone or in combination with docetaxel in locally advanced squamous-cell cancer of the head and neck: long-term results of the TAX 324 randomised phase 3 trial. Lancet Oncol. 2011;12(2):153-9.

Lubin JH, Purdue M, Kelsey K, Zhang ZF, Winn D, Wei Q, Talamini R, Szeszenia-Dabrowska N, Sturgis EM, Smith E, Shangina O, Schwartz SM, Rudnai P, Neto JE, Muscat J, Morgenstern H, Menezes A, Matos E, Mates IN, Lissowska J, Levi F, Lazarus P, La Vecchia C, Koifman S, Herrero R, Franceschi S, Wünsch-Filho V, Fernandez L, Fabianova E, Daudt AW, Maso LD, Curado MP, Chen C, Castellsague X, Brennan P, Boffetta P, Hashibe M, Hayes RB. Total exposure and exposure rate effects for alcohol and smoking and risk of head and neck cancer: a pooled analysis of case-control studies. Am J Epidemiol. 2009 Oct 15;170(8):937-47.

Lu J, Getz G, Miska EA, Alvarez-Saavedra E, Lamb J, Peck D, Sweet-Cordero A, Ebert BL, Mak RH, Ferrando AA, Downing JR, Jacks T, Horvitz HR, Golub TR. MicroRNA expression profiles classify human cancers. Nature. 2005 Jun 9; 435(7043):834-8.

Lv M, Zhang X, Jia H, Li D, Zhang B, Zhang H, Hong M, Jiang T, Jiang Q, Lu J, Huang X, Huang B. An oncogenic role of miR-142-3p in human T-cell acute lymphoblastic leukemia (TALL) by targeting glucocorticoid receptor- $\alpha$ and cAMP/PKA pathways. Leukemia. 2012 Apr;26(4):769-77.

Maia D, de Carvalho AC, Horst MA, Carvalho AL, Scapulatempo-Neto C, Vettore AL. Expression of miR-296-5p as predictive marker for radiotherapy resistance in early-stage laryngeal carcinoma. J Transl Med. 2015 Aug 12;13:262.

Manikandan M, Deva Magendhra Rao AK, Rajkumar KS, Rajaraman R, Munirajan AK. Altered levels of miR-21, miR-125b-2*, miR-138, miR-155, miR-184, and miR-205 in oral squamous cell carcinoma and association with clinicopathological characteristics. J Oral Pathol Med. 2015 Nov;44(10):792-800.

Manikandan M, Deva Magendhra Rao AK, Arunkumar G, Manickavasagam M, Rajkumar KS, Rajaraman R, Munirajan AK. Oral squamous cell carcinoma: microRNA expression profiling and integrative analyses for elucidation of tumourigenesis mechanism. Mol Cancer. 2016 Apr $7 ; 15: 28$. 
Maroney PA, Yu Y, Fisher J, Nilsen TW. Evidence that microRNAs are associated with translating messenger RNAs in human cells. Nat Struct Mol Biol. 2006

Maselli V, Di Bernardo D, Banfi S. CoGemiR: a comparative genomics microRNA database. BMC Genomics. 2008 Oct 6;9:457.

Mathivanan S, Ji H, Simpson RJ. Exosomes: extracellular organelles important in intercellular communication. J Proteomics 2010; 73:1907-1920.

Mathivanan S, Fahner CJ, Reid GE, Simpson RJ. ExoCarta 2012: database of exosomal proteins, RNA and lipids. Nucleic Acids Res. 2012 Jan;40(Database issue): D1241-4.

McLellan AD. Exosome release by primary B cells.Crit Rev Immunol. 2009; 29(3): 203-17.

Metzger R, Leichman CG, Danenberg KD, Danenberg PV, Lenz HJ, Hayashi K, Groshen S, Salonga D, Cohen H, Laine L, Crookes P, Silberman H, Baranda J, Konda B, Leichman L. ERCC1 mRNA levels complement thymidylate synthase mRNA levels in predicting response and survival for gastric cancer patients receiving combination cisplatin and fluorouracil chemotherapy. J Clin Oncol. 1998 Jan; 16(1):309-16.

Michael J. McCullough, Gareema Prasad, Sarah Zhao and Camile S. Farah (2012). The Changing Aetiology of Oral Cancer and the Role of Novel Biomarkers to Aid in Early Diagnosis, Oral Cancer, Dr. Kalu U. E. Ogbureke (Ed.), ISBN: 978-953-51-0228-1, InTech, Available from: http://www.intechopen.com/books/oral-cancer/thechanging-aetiology-of-oralcancer-and-the-role-of-novel-biomarkers-to-aid-in-early-diagnosis

Miller TE, Ghoshal K, Ramaswamy B, Roy S, Datta J, Shapiro C Let al. (2008). MicroRNA221/222 confers tamoxifen resistance in breast cancer by targeting p27Kip1. J Biol Chem 283: 29897-29903.

Mirbase: the microRNA data base. Acesso em: http://www.mirbase.org/index.shtml

Mitchell PS, Parkin RK, Kroh EM, Fritz BR, Wyman SK, Pogosova-Agadjanyan EL, Peterson A, Noteboom J, O'Briant KC, Allen A, Lin DW, Urban N, Drescher CW, Knudsen BS, StirewaltDL,Gentleman R, Vessella RL, Nelson PS, Martin DB, Tewari M. Circulating microRNAs as stable blood-based markers for cancer detection. Proc Natl Acad Sci USA 2008; 105:10513-10518.

Mittelbrunn M, Gutierrez-Vazquez C, Villarroya-Beltri C, Gonzalez S, Sanchez-Cabo F, Gonzalez MA, Bernad A, S'anchez-Madrid F. Unidirectional transfer of microRNA-loaded exosomes from T cells to antigenpresenting cells. Nat Commun 2011, 2:282.

Mohankumar S, Patel T. Extracellular vesicle long noncoding RNA as potential biomarkers of liver cancer. Brief Funct Genomics. 2016 May;15(3):249-56.

Moreland NJ, Illand M, Kim YT, Paul J, Brown R. Modulation of drug resistance mediated by loss of mismatch repair by the DNA polymerase inhibitor aphidicolin. Cancer Res. 1999 May 1;59(9):2102-6.

Morelli AE, Larregina AT, Shufesky WJ, Sullivan ML, Stolz DB, Papworth GD, Zahorchak AF, Logar AJ, Wang Z, Watkins SC, Falo LD Jr, Thomson AW. Endocytosis, intracellular sorting, and processing of exosomes by dendritic cells.Blood. 2004 Nov 15; 104(10):3257-66. 
Munagala R, Aqil F, Gupta RC. Exosomal miRNAs as biomarkers of recurrent lung cancer. Tumour Biol. 2016 Feb 11.

Mydlarz WK, Hennessey PT, Wang H, Carvalho AL, Califano JA. Serum biomarkers for detection of head and neck squamous cell carcinoma. Head Neck. 2016 Jan;38(1):9-14.

Nabhan JF, Hu R, Oh RS, Cohen SN, Lu Q. Formation and release of arrestin domaincontaining protein 1-mediated microvesicles (ARMMs) at plasma membrane by recruitment of TSG101 protein. Proc Natl Acad Sci USA. 2012 Mar 13; 109 (11): 4146-51.

Nagadia R, Pandit P, Coman WB, Cooper-White J, Punyadeera C. miRNAs in head and neck cancer revisited. Cell Oncol (Dordr). 2013 Feb;36(1):1-7.

Nakatani F, Ferracin M, Manara MC, Ventura S, Del Monaco V, Ferrari S, Alberghini M, Grilli A, Knuutila S, Schaefer KL, Mattia G, Negrini M, Picci P, Serra M, Scotlandi K. miR-34a predicts survival of Ewing's sarcoma patients and directly influences cell chemo-sensitivity and malignancy. J Pathol. 2012 Apr; 226(5):796-805.

Nakanishi H, Taccioli C, Palatini J, Fernandez-Cymering C, Cui R, Kim T, Volinia S, Croce CM. Loss of miR-125b-1 contributes to head and neck câncer development by dysregulating TACSTD2 and MAPK pathway. Oncogene. 2014 Feb 6;33(6):702-12.

Neilson JR, Zheng GX, Burge CB, Sharp PA. Dynamic regulation of miRNA expression in ordered stages of cellular development. Genes Dev. 2007 Mar 1;21(5):578-89.

Neves, A. P.; Vargas, M. D. Complexos de Platina(II) na Terapia do Câncer. Rev. Virtual Quim., 2011, 3 (3), 196-209. Data de publicação na Web: 5 de setembro de 2011. http://www.uff.br/rvq

Nichols AC, Finkelstein DM, Faquin WC, Westra WH, Mroz EA, Kneuertz P, Begum S, Michaud WA, Busse PM, Clark JR, Rocco JW. Bcl2 and human papilloma virus 16 as predictors of outcome following concurrent chemoradiation for advanced oropharyngeal cancer. Clin Cancer Res. 2010 Apr 1;16(7):2138-46.

Nilsson J, Skog J, Nordstrand A, Baranov V, Mincheva-Nilsson L, Breakefield XO, Widmark A. Prostate cancer-derived urine exosomes: a novel approach to biomarkers for prostate cancer. Br J Cancer. 2009 May 19;100(10):1603-7.

Ogawa Y, Kanai-Azuma M, Akimoto Y, Kawakami H, Yanoshita R. Exosome-like vesicles with dipeptidyl peptidase IV in human saliva. Biol Pharm Bull. 2008 Jun; 31(6):1059-62.

Nottrott S, Simard MJ, Richter JD. Human let-7a miRNA blocks protein production on actively translating polyribosomes. Nat Struct Mol Biol. 2006.

Ohnishi K, Ota I, Takahashi A, Yane K, Matsumoto H, Ohnishi T. Transfection of mutant p53 gene depresses X-ray- or CDDP-induced apoptosis in a human squamous cell carcinoma of the head and neck. Apoptosis. 2002 Aug;7(4):367-72.

Okamura K, Hagen JW, Duan H, Tyler DM, Lai EC. The mirtron pathway generates microRNA-class regulatory RNAs in Drosophila. Cell. 2007 Jul 13;130(1):89-100.

Olaussen KA, Dunant A, Fouret P, Brambilla E, André F, Haddad V, Taranchon E, Filipits M, Pirker R, Popper HH, Stahel R, Sabatier L, Pignon JP, Tursz T, Le Chevalier T, Soria JC; IALT 
Bio Investigators. DNA repair by ERCC1 in non-small-cell lung cancer and cisplatin-based adjuvant chemotherapy. $N$ Engl J Med. 2006 Sep 7; 355(10):983-91.

Olena AF, Patton JG. Genomic organization of microRNAs. J Cell Physiol. 2010 Mar;222(3):540-5.

Ou DL, Chien HF, Chen CL, Lin TC, Lin LI. Role of Twist in head and neck carcinoma with lymph node metastasis. Anticancer Res. 2008 Mar-Apr;28(2B):1355-9.

Pal A, Melling G, Hinsley EE, Kabir TD, Colley HE, Murdoch C, Lambert DW. Cigarette smoke condensate promotes pro-tumourigenic stromal-epithelial interactions by suppressing miR-145. J Oral Pathol Med. 2013 Apr;42(4):309-14.

Palatnik JF, Allen E, Wu X, Schommer C, Schwab R, Carrington JC, Weigel D. Control of leaf morphogenesis by microRNAs. Nature. 2003 Sep 18;425(6955):257-63

Park NJ, Zhou H, Elashoff D, Henson BS, Kastratovic DA, Abemayor E, Wong DT. Salivary microRNA: discovery, characterization, and clinical utility for oral cancer detection. Clin Cancer Res. 2009 Sep 1;15(17):5473-7.

Parness J, Horwitz SB. Taxol binds to polymerized tubulin in vitro. J Cell Biol. 1981 Nov;91(2 Pt 1):479-87.

Parolini I, Federici C, Raggi C, Lugini L, Palleschi S, De Milito A, Coscia C,Iessi E, Logozzi M, Molinari A, Colone M, Tatti M, Sargiacomo M, Fais S. Microenvironmental $\mathrm{pH}$ is a key factor for exosome traffic in tumor cells. J Biol Chem. 2009 Dec 4; 284 (49):34211-22.

Peinado H, Lavotshkin S, Lyden D. The secreted factors responsible for premetastatic niche formation: old sayings and new thoughts. Semin Cancer Biol 2011; 21:139-146.

Peinado H, Aleckovic M, Lavotshkin S, et al. Melanoma exosomes educate bone marrow progenitor cells toward a pro-metastatic phenotype through MET. Nat Med 2012; 18:883-891.

Peltier HJ, Latham GJ. Normalization of microRNA expression levels in quantitative RT-PCR assays: identification of suitable reference RNA targets in normal and cancerous human solid tissues. RNA. 2008 May;14(5):844-52.

Pestova TV, Kolupaeva VG, Lomakin IB, Pilipenko EV, Shatsky IN, Agol VI,Hellen CU. Molecular mechanisms of translation initiation in eukaryotes. Proc Natl Acad Sci USA. 2001 Jun 19;98(13):7029-36. Review.

Petersen CP, Bordeleau ME, Pelletier J, Sharp PA. Short RNAs repress translation after initiation in mammalian cells. Mol Cell. 2006 Feb 17;21(4):533-42.

Pignon JP, le Maitre A, Maillard E, Bourhis J. Meta-analysis of chemotherapy in head and neck cancer (MACH-NC): an update on 93 randomised trials and 17,346 patients. Radiother Oncol. 2009;92(1):4-14.

Pilzer D, Gasser O, Moskovich O, Schifferli JA, Fishelson Z. Emission of membrane vesicles: roles in complement resistance, immunity and cancer. Springer Semin Immunopathol. 2005 Nov; 27(3):375-87.

Pisitkun T, Shen RF, Knepper MA. Identification and proteomic profiling of exosomes in human urine.Proc Natl Acad Sci USA. 2004 Sep 7;101(36):13368-73. 
Platta HW, Stenmark H. Endocytosis and signaling. Curr Opin Cell Biol 2011, 23:393-403.

Pogribny IP, Filkowski JN, Tryndyak VP, Golubov A, Shpyleva SI, Kovalchuk O. Alterations of microRNAs and their targets are associated with acquired resistance of MCF-7 breast cancer cells to cisplatin. Int J Cancer. 2010 Oct 15;127(8):1785-94.

Posner M, Vermorken JB. Induction therapy in the modern era of combined-modality therapy for locally advanced head and neck cancer. Semin Oncol. 2008 Jun; 35(3):221-8.

Principe S, Hui AB, Bruce J, Sinha A, Liu FF, Kislinger T. Tumor-derived exosomes and microvesicles in head and neck cancer: implications for tumor biology and biomarker discovery. Proteomics. 2013 May; 13(10-11):1608-23. Review.

Puram SV, Rocco JW. Molecular Aspects of Head and Neck Cancer Therapy. Hematol Oncol Clin North Am. 2015 Dec;29(6):971-92.

Qiu T, Zhou L, Wang T, Xu J, Wang J, Chen W, Zhou X, Huang Z, Zhu W, Shu Y, Liu P: miR503 regulates the resistance of non-small cell lung cancer cells to cisplatin by targeting Bcl-2. Int J Mol Med 2013;32:593-598.

Ramdas L, Giri U, Ashorn CL, Coombes KR, El-Naggar A, Ang KK, Story MD. miRNA expression profiles in head and neck squamous cell carcinoma and adjacent normal tissue. Head Neck. 2009 May;31(5):642-54.

Ramachandran S, Palanisamy V. Horizontal transfer of RNAs: exosomes as mediators of intercellular communication. Wiley Interdiscip Rev RNA. 2012 Mar-Apr;3(2):286-93.

Raposo G, Stoorvogel W. Extracellular vesicles: exosomes, microvesicles, and friends. J Cell Biol. 2013 Feb 18;200(4):373-83. doi: 10.1083/jcb.201211138. Review.

Ratajczak J, Miekus K, Kucia M, Zhang J, Reca R, Dvorak P, Ratajczak MZ. Embryonic stem cell-derived microvesicles reprogram hematopoietic progenitors: evidence for horizontal transfer of mRNA and protein delivery. Leukemia. 2006 May;20(5):847-56.

Reid G, Kirschner MB, van Zandwijk N. Circulating microRNAs: Association with disease and potential use as biomarkers. Crit Rev Oncol Hematol. 2011Nov; 80(2):193-208.

Reinhart BJ, Slack FJ, Basson M, Pasquinelli AE, Bettinger JC, Rougvie AE, Horvitz HR, Ruvkun G. The 21-nucleotide let-7 RNA regulates developmental timing in Caenorhabditis elegans. Nature. 2000 Feb 24;403(6772):901-6.

Roberson CD, Atay S, Gercel-Taylor C, Taylor DD. Tumor-derived exosomes as mediators of disease and potential diagnostic biomarkers. Cancer Biomark 2010; 8:281-291.

Sadowski L, Pilecka I, Miaczynska M. Signaling from endosomes: location makes a difference. Exp Cell Res. 2009 May 15;315(9):1601-9.

Sanabria, Alvaro; Domenge, Christian; D'Cruz, Anil; Kowalski, Luiz P d. Organ preservation protocols in developing countries. Otolaryngology \& Head \& Neck Surgery 2010, 8(2):83-88.

Scapoli L, Palmieri A, Lo Muzio L, Pezzetti F, Rubini C, Girardi A, Farinella F, Mazzotta M, Carinci F. MicroRNA expression profiling of oral carcinoma identifies new markers of tumor progression. Int J Immunopathol Pharmacol. 2010 Oct-Dec;23(4):1229-34. 
Schorey JS, Cheng Y, Singh PP, Smith VL. Exosomes and other extracelular vesicles in hostpathogen interactions. EMBO Rep. 2015 Jan;16(1):24-43.

Scully C, Epstein JB. Oral health care for the cancer patient. Eur J Cancer B Oral Oncol. 1996 Sep;32B(5):281-92. Review.

Selcuklu SD, Donoghue MT, Spillane C. miR-21 as a key regulator of oncogenic processes. Biochem Soc Trans. 2009 Aug;37(Pt 4):918-25. Review.

Sethi N, Wright A, Wood H, Rabbitts P. MicroRNAs and head and neck cancer: reviewing the first decade of research. Eur J Cancer. 2014 Oct;50(15):2619-35. Review.

Shenouda SK, Alahari SK (2009) MicroRNA function in cancer: oncogene or a tumor suppressor? Cancer Metastasis Rev 28:369-378

Shi W, Kato H, Perez-Ordonez B, Pintilie M, Huang S, Hui A, O'Sullivan B,Waldron J, Cummings B, Kim J, Ringash J, Dawson LA, Gullane P, Siu L, Gillison M,Liu FF. Comparative prognostic value of HPV16 E6 mRNA compared with in situ hybridization for human oropharyngeal squamous carcinoma. J Clin Oncol. 2009 Dec 20; 27(36):6213-21.

Shiiba M, Shinozuka K, Saito K, Fushimi K, Kasamatsu A, Ogawara K, Uzawa K, Ito H, Takiguchi Y, Tanzawa $\mathrm{H}$. MicroRNA-125b regulates proliferation and radioresistance of oral squamous cell carcinoma. Br J Cancer. 2013 May 14;108(9):1817-21.

Simpson RJ, Lim JW, Moritz RL, Mathivanan S. Exosomes: proteomic insights and diagnostic potential. Expert Rev Proteomics 2009; 6:267-283.

Skog J, Würdinger T, van Rijn S, Meijer DH, Gainche L, Sena-Esteves M, Curry WT Jr, Carter BS, Krichevsky AM, Breakefield XO. Glioblastoma microvesicles transport RNA and proteins that promote tumour growth and provide diagnostic biomarkers. Nat Cell Biol. 2008 Dec;10(12):1470-6.

SLAUGHTER DP, SOUTHWICK HW, SMEJKAL W. Field cancerization in oral stratified squamous epithelium; clinical implications of multicentric origin. Cancer. 1953 Sep;6(5):963-8.

Somers KD, Merrick MA, Lopez ME, Incognito LS, Schechter GL, Casey G. Frequent p53 mutations in head and neck cancer. Cancer Res. 1992 Nov 1;52(21):5997-6000

Stransky N, Egloff AM, Tward AD, Kostic AD, Cibulskis K, Sivachenko A, Kryukov GV, Lawrence MS, Sougnez C, McKenna A, Shefler E, Ramos AH, Stojanov P, Carter SL, Voet D, Cortés ML, Auclair D, Berger MF, Saksena G, Guiducci C, Onofrio RC,Parkin M, Romkes M, Weissfeld JL, Seethala RR, Wang L, Rangel-Escareño C,Fernandez-Lopez JC, HidalgoMiranda A, Melendez-Zajgla J, Winckler W, Ardlie K,Gabriel SB, Meyerson M, Lander ES, Getz G, Golub TR, Garraway LA, Grandis JR. The mutational landscape of head and neck squamous cell carcinoma. Science. 2011 Aug 26;333(6046):1157-60.

Sun L, Yao Y, Liu B, Lin Z, Lin L, Yang M, Zhang W, Chen W, Pan C, Liu Q, Song E, Li J. MiR-200b and miR-15b regulate chemotherapy-inducedepithelial-mesenchymal transition in human tongue cancer cells by targeting BMI1. Oncogene. 2012 Jan 26;31(4):432-45.

Shirota Y, Stoehlmacher J, Brabender J, Xiong YP, Uetake H, DanenbergKD,Groshen S, TsaoWei DD, Danenberg PV, Lenz HJ. ERCC1 and thymidylate synthase mRNA levels predict survival for colorectal cancer patients receiving combination oxaliplatin and fluorouracil chemotherapy. J Clin Oncol. 2001 Dec 1; 19 (23):4298-304. 
Skriner K, Adolph K, Jungblut PR, Burmester GR. Association of citrullinated proteins with synovial exosomes. Arthritis Rheum. 2006 Dec;54(12):3809-14.

Soini HA, Klouckova I, Wiesler D, Oberzaucher E, Grammer K, Dixon SJ, Xu Y, Brereton RG, Penn DJ, Novotny MV.Analysis of volatile organic compounds in human saliva by a static sorptive extraction method and gas chromatography-mass spectrometry.J Chem Ecol. 2010 Sep; 36(9):1035-42.

Sorrentino A, Liu CG, Addario A, Peschle C, Scambia G, Ferlini C. Role of MicroRNAs in drug-resistant ovarian cancer cells. Gynecol Oncol. 2008 Dec;111(3):478-86.

Streckfus CF, Dubinsky WP. Proteomic analysis of saliva for cancer diagnosis.Expert Rev Proteomics 2007; 4 (3):329-32.

Street JM, Barran PE, Mackay CL, Weidt S, Balmforth C, Walsh TS, Chalmers RT, Webb DJ, Dear JW. Identification and proteomic profiling of exosomes in human cerebrospinal fluid.J Transl Med. 2012 Jan 5;10:5.

Stoorvogel W, Kleijmeer MJ, Geuze HJ, Raposo G. The biogenesis and functions of exosomes.Traffic. 2002 May;3(5):321-30. Review.

Subra C, Grand D, Laulagnier K, Stella A, Lambeau G, Paillasse M, De Medina P, Monsarrat B, Perret B, Silvente-Poirot S, Poirot M, Record M. Exosomes account for vesicle-mediated transcellular transport of activatable phospholipases and prostaglandins. J Lipid Res. 2010 Aug; 51(8): 2105-20.

Summerer I, Unger K, Braselmann H, Schuettrumpf L, Maihoefer C, Baumeister P, Kirchner T, Niyazi M, Sage E, Specht HM, Multhoff G, Moertl S, Belka C,Zitzelsberger H. Circulating microRNAs as prognostic therapy biomarkers in head and neck cancer patients. Br J Cancer. 2015 Jun 30;113(1):76-82.

Sun L, Yao Y, Liu B, Lin Z, Lin L, Yang M, Zhang W, Chen W, Pan C, Liu Q, Song E, Li J. MiR-200b and miR-15b regulate chemotherapy-induced epithelial-mesenchymal transition in human tongue cancer cells by targeting BMI1. Oncogene. 2012 Jan 26; 31(4):432-45.

Sun YM, Lin KY, Chen YQ. Diverse functions of miR-125 family in different cell contexts. J Hematol Oncol. 2013 Jan 15;6:6.

Syrjänen KJ, Pyrhönen S, Syrjänen SM, Lamberg MA. Immunohistochemical demonstration of human papilloma virus (HPV) antigens in oral squamous cell lesions. Br J Oral Surg. 1983;21(2):147-53.

Taylor DD, Gercel-Taylor C. MicroRNA signatures of tumor-derived exosomes as diagnostic biomarkers of ovarian cancer. Gynecol Oncol. 2008 Jul;110(1):13-21. Erratum in: Gynecol Oncol. 2010 Jan;116(1):153.

Thakur BK, Zhang H, Becker A, Matei I, Huang Y, Costa-Silva B, Zheng Y, Hoshino A, Brazier H, Xiang J, Williams C, Rodriguez-Barrueco R, Silva JM, Zhang W, Hearn S, Elemento O, Paknejad N, Manova-Todorova K, Welte K, Bromberg J, Peinado H, Lyden D. Doublestranded DNA in exosomes: a novel biomarker in cancer detection. Cell Res. 2014 Jun;24(6):766-9. 
Thery C, Zitvogel L, Amigorena S. Exosomes: composition, biogenesis and function. Nat Rev Immunol 2002; 2:569-579.

Théry C, Ostrowski M, Segura E. Membrane vesicles as conveyors of imune responses. Nat Rev Immunol. 2009 Aug; 9(8):581-93. Review.

Tovar-Camargo OA, Toden S, Goel A. Exosomal microRNA Biomarkers: Emerging Frontiers in Colorectal and Other Human Cancers. Expert Rev Mol Diagn. 2016;16(5):553-67.

Valadi H, Ekström K, Bossios A, Sjöstrand M, Lee JJ, Lötvall JO. Exosome-mediated transfer of mRNAs and microRNAs is a novel mechanism of genetic exchange between cells. Nat Cell Biol. 2007 Jun;9(6):654-9.

Wakiyama M, Takimoto K, Ohara O, Yokoyama S. Let-7 microRNA-mediated mRNA deadenylation and translational repression in a mammalian cell-free system. Genes Dev. 2007 Aug 1;21(15):1857-62. Erratum in: Genes Dev. 2007 Oct 1;21(19):2509.

Wang And X, Guo Z. The role of sulfur in platinum anticancer chemotherapy.Anticancer Agents Med Chem. 2007 Jan;7(1):19-34. Review.

Wang W, Songlin P, Sun Y, Zhang B, Jinhui W. miR-21 inhibitor sensitizes human OSCC cells to cisplatin. Mol Biol Rep. 2012 May;39(5):5481-5.

Wang XC, Wang W, Zhang ZB, Zhao J, Tan XG, Luo JC. Overexpression of miRNA-21 promotes radiation-resistance of non-small cell lung cancer. Radiat Oncol. 2013 Jun 19;8:146

Ward, J. F..Nature of lesions formed by ionizing radiation, p. 65-84. In J. A. Nickoloff and M. F. Hoekstra (ed.), DNA damage and repair, vol. II. DNA repair in higher eukaryotes. Humana Press, Totowa, N.J. 1998.

Warnakulasuriya S. Causes of oral cancer--an appraisal of controversies.Br Dent J. 2009 Nov 28; 207(10):471-5.

Wei J, Gao W, Zhu CJ, Liu YQ, Mei Z, Cheng T, Shu YQ. Identification of plasma microRNA21 as a biomarker for early detection and chemosensitivity of non-small cell lung cancer. Chin J Cancer. 2011 Jun;30(6):407-14.

WHO. International statistic classification of diseases and related health problems 10th revision (ICD-10). 2010.

Wiest T, Schwarz E, Enders C, Flechtenmacher C, Bosch FX. Involvement of intact HPV16 E6/E7 gene expression in head and neck cancers with unaltered p53 status and perturbed pRb cell cycle control.Oncogene. 2002 Feb 28;21(10):1510-7.

Wightman B, Ha I, Ruvkun G. Posttranscriptional regulation of the heterochronic gene lin-14 by lin-4 mediates temporal pattern formation in C. elegans. Cell. 1993 Dec 3;75(5):855-62.

Wilson GD, Bentzen SM, Harari PM. Biologic basis for combining drugs with radiation.Semin Radiat Oncol. 2006 Jan; 16(1):2-9. Review.

Wong TS, Liu XB, Wong BY, Ng RW, Yuen AP, Wei WI. Mature miR-184 as Potential Oncogenic microRNA of Squamous Cell Carcinoma of Tongue. Clin Cancer Res. 2008 May $1 ; 14(9): 2588-92$. 
Wu BH, Xiong XP, Jia J, Zhang WF. MicroRNAs: new actors in the oral câncer scene. Oral Oncol. 2011 May;47(5):314-9. Review.

Wurdinger T, Gatson NN, Balaj L, Kaur B, Breakefield XO, Pegtel DM. Extracellular vesicles and their convergence with viral pathways. Adv Virol.2012; 2012:767694.

Xie Z, Chen G, Zhang X, Li D, Huang J, Yang C, Zhang P, Qin Y, Duan Y, Gong B, Li Z. Salivary microRNAs as promising biomarkers for detection of esophageal cancer. PLoS One. 2013;8(4):e57502.

Yan W, Apweiler R, Balgley BM, Boontheung P, Bundy JL, Cargile BJ, Cole S, Fang X, Gonzalez-Begne M, Griffin TJ, Hagen F, Hu S, Wolinsky LE, Lee CS, Malamud D, Melvin JE, Menon R, Mueller M, Qiao R, Rhodus NL, Sevinsky JR, States D, Stephenson JL, Than S, Yates JR, Yu W, Xie H, Xie Y, Omenn GS, Loo JA, Wong DT. Systematic comparison of the human saliva and plasma proteomes. Proteomics Clin Appl. 2009 Jan 1;3(1):116-134.

Yang LX, Douple EB, O'Hara JA, Wang HJ. Production of DNA double-strand breaks by interactions between carboplatin and radiation: a potential mechanism for radiopotentiation. Radiat Res. 1995 Sep; 143(3):309-15.

Yang SM, Huang C, Li XF, Yu MZ, He Y, Li J. miR-21 confers cisplatin resistance in gastric cancer cells by regulating PTEN. Toxicology. 2013 Apr 5;306:162-8.

Ye M, Ye P, Zhang W, Rao J, Xie Z. [Diagnostic values of salivary versus and plasma microRNA-21 for early esophageal cancer]. Nan Fang Yi Ke Da Хие Хие Bao. 2014 Jun;34(6):885-9.

Yu ZW,Zhong LP, Ji T,Zhang P, Chen WT, Zhang CP., MicroRNAs contribute to the chemoresistance of cisplatin in tongue squamous cell carcinoma lines, Oral Oncol.2010 Apr; 46(4):317-22.

Yu ZW, Zhong LP, Ji T, Zhang P, Chen WT, Zhang CP. MicroRNAs contribute to the chemoresistance of cisplatin in tongue squamous cell carcinoma lines. Oral Oncol.

2010 Apr;46(4):317-22.

Yu PN, Yan MD, Lai HC, Huang RL, Chou YC, Lin WC, Yeh LT, Lin YW.Downregulation of miR-29 contributes to cisplatin resistance of ovarian câncer cells. Int J Cancer. 2014 Feb $1 ; 134(3): 542-51$.

Zhao D, Xu QG, Chen XM, Fan MW. Human papillomavirus as an independent predictor in oral squamous cell cancer.Int J Oral Sci. 2009 Sep;1(3):119-25.

Zheng ZM, Wang X. Regulation of cellular miRNA expression by human papillomaviruses. Biochim Biophys Acta. 2011 Nov-Dec;1809(11-12):668-77.

Znaor A, Brennan P, Gajalakshmi V, Mathew A, Shanta V, Varghese C, et al. Independent and combined effects of tobacco smoking, chewing and alcohol drinking on the risk of oral, pharyngeal and esophageal cancers in Indian men. Int J Cancer. 2003;105(5):681-6.

Zou Z, Wu L, Ding H, Wang Y, Zhang Y, Chen X, Chen X, Zhang CY, Zhang Q, Zen K. MicroRNA-30a sensitizes tumor cells to cis-platinum via suppressing beclin1-mediated autophagy. J Biol Chem. 2012 Feb 3; 287(6):4148-56. 
Zlotogorski-Hurvitz A, Dayan D, Chaushu G, Korvala J, Salo T, Sormunen R,Vered M. Human saliva-derived exosomes: comparing methods of isolation. J Histochem Cytochem. 2015 Mar;63(3):181-9.

Zeisberg M, Neilson EG. Biomarkers for epithelial-mesenchymal transitions. J Clin Invest. 2009 Jun;119(6):1429-37.

Zhang Y, Fan M, Zhang X, Huang F, Wu K, Zhang J, Liu J, Huang Z, Luo H, Tao L,Zhang H. Cellular microRNAs up-regulate transcription via interaction with promoter TATA-box motifs. RNA. 2014 Dec;20(12):1878-89.

Zhang L, Zhang S, Yao J, Lowery FJ, Zhang Q, Huang WC, Li P, Li M, Wang X, Zhang C, Wang H, Ellis K, Cheerathodi M, McCarty JH, Palmieri D, Saunus J, Lakhani S, Huang S, Sahin AA, Aldape KD, Steeg PS, Yu D. Microenvironment-induced PTEN loss by exosomal microRNA primes brain metastasis outgrowth. Nature. 2015 Nov 5;527(7576):100-4.

Zhao Z, Ge J, Sun Y, Tian L, Lu J, Liu M, Zhao Y. Is E-cadherin immunoexpression a prognostic factor for head and neck squamous cell carcinoma (HNSCC)? A systematic review and meta-analysis. Oral Oncol. 2012 Sep;48(9):761-7.

Zhu W, Xu H, Zhu D, Zhi H, Wang T, Wang J, Jiang B, Shu Y, Liu P. miR-200bc/429 cluster modulates multidrug resistance of human cancer cell lines by targeting BCL2 and XIAP. Cancer Chemother Pharmacol. 2012 Mar;69(3):723-31. 


\section{APÊNDICES}

CANCER

DIETADOE

SAO PAULO

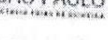

\section{INSTITUTO DO CANCER DO ESTADO DE SÃO PAULO \\ Octávio Frias de Oliveira \\ Secretaria de Estado da Saúd}

Faculdade de Medicina da Universidade de São Paulo

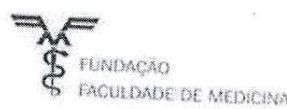

Registro: NP 311/12

São Paulo, 08 de outubro de 2012

Ref. Solicitação de execução de estudo: “Identificação de microRNASs e possiveis genes alvos na saliva associados ao benefício a longo prazo da quimiora microRNASs e possíveis genes alvos na epidermóide de cavidade oral e orofaringe."

Pesquisador responsável: Dr.

\section{CONSIDERAÇÕES} mestrado.

Trata-se de um estudo observacional analítico de coorte prospectivo, com finalidade de

O objetivo é identificar microRNAs relacionados ao tratamento de quimiorradioterapia a base de cisplatina em pacientes com carcinoma localmente avançados e irressecáveis.

Serão incluídos 120 paciente

três grupos: a) pacientes portacientes do Instituto do Câncer de São Paulo (ICESP), divididos em tratamento prévio; b) pacientes que ap doença localmente avançada e irressecável sem doença pós quimioradioterapia (QRT). (QRT) definitiva.

Será solicitadc de materiais plásticos, reagentes e kits para determinação dos microRNAs, isso envolve aquisição in específicos para aplicação da metodologia.

\section{RESPONSABILIDADES DO PESQUISADOR}

Antes do início dos procedimentos relacionados ao estudo:

- Iniciar as atividades do estudo somente após aprovação/ciência do Comitê de Ética em Pesquisa para execução no ICESP segundo a Res. 196/96;

ciência do CEP ao NP- ICESP.

- Envia cópia do

ermo de Outorga

processos de coordenação de pesquisa e planejamento enterita de pesquisa para orientar mas não pode alocar recurso humanisa e planejamento dos pacientes ao grupo executor

Informamos que sua solicitação foi DEFERIDA

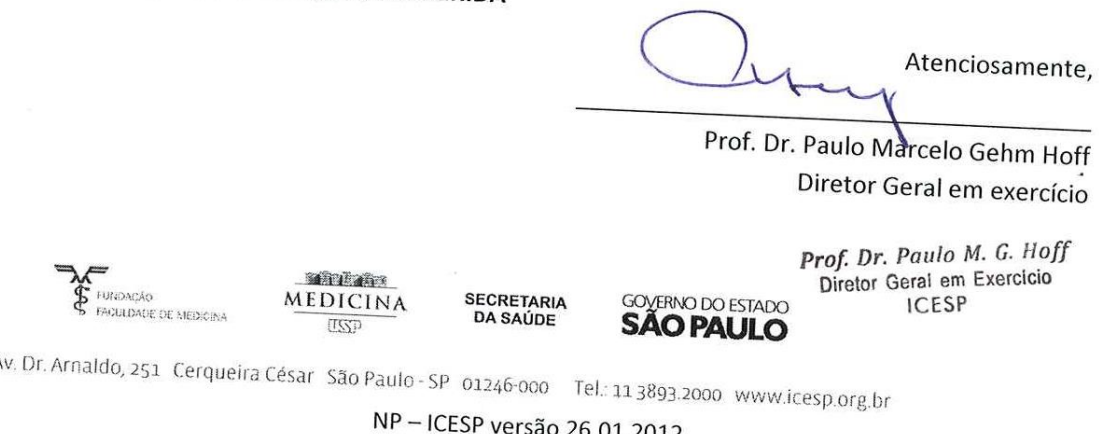

NP - ICESP versão 26.01.2012 


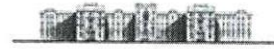 \\ MEDICINA \\ TSP \\ COMITÊ DE ÉTICA EM PESQUISA}

\section{CIÊNCIA}

O Comitê de Ética em Pesquisa da Faculdade de Medicina da Universidade de São Paulo, em sessão de 03 de Setembro de 2014, TOMOU CIÊNCIA do(s) documento(s) abaixo mencionado(s) no Protocolo de Pesquisa $n^{\circ} 390 / 12$, intitulado: "Identificação de microRNAs e possiveis genes alvos na saliva associados ao benefício a longo prazo da quimiorradioterapia em pacientes com carcinoma epidermóide de cavidade oral e orofaringe" apresentado pelo Instituto do Câncer do Estado de São Paulo "Ocłávio Frias de Oliveira."

- MM 773/14-Comunicado de desligamento do pesquisador responsável Dr. Igor Moisés Longo e substiłuição por Dra. Fátima Solange Pasini.

Pesquisador (a) Responsável: Dra. Fátima Solange Pasini

CEP-FMUSP, 05 de Setembro de 2014.

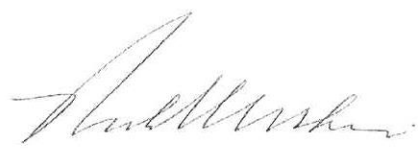

Prof. Dr. Paulo Eurípedes Marchiori

Vice-Coordenador

Comitê de Ética em Pesquisa 